\title{
HYDROLOGIC CONDITIONS AND DISTRIBUTION OF SELECTED RADIOCHEMICAL AND CHEMICAL CONSTITUENTS IN WATER, SNAKE RIVER PLAIN AQUIFER, IDAHO NATIONAL ENGINEERING LABORATORY, IDAHO, 1989 THROUGH 1991
}

By ROY C. BARTHOLOMAY, BRENNON R. ORR, MICHAEL J. LISZEWSKI, and RODGER G. JENSEN

\section{U.S. GEOLOGICAL SURVEY}

Water-Resources Investigations Report 95-4175

Prepared in cooperation with the U.S. DEPARTMENT OF ENERGY

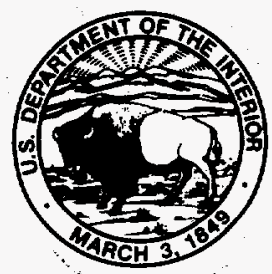




\section{U.S. DEPARTMENT OF THE INTERIOR \\ BRUCE BABBITT, Secretary}

U.S. GEOLOGICAL SURVEY

Gordon P. Eaton, Director

For additional information write to:

U.S. Geological Survey

INEL, MS 4148

P.O. Box 2230

Idaho Falls, ID 83403-2230
Copies of this report can be purchased from:

\section{U.S. Geological Survey}

Earth Science Information Center

Open-File Reports Section

Box 25286, MS 517, Denver Federal Center

Denver, CO 80225 


\section{DISCLAMMER}

Portions of this document may be illegible in electronic image products. Images are produced from the best available original document. 


\section{CONTENTS}

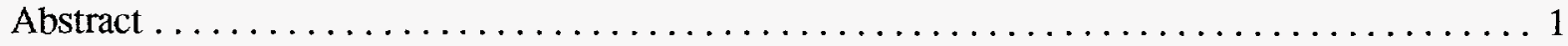

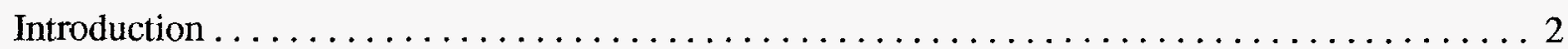

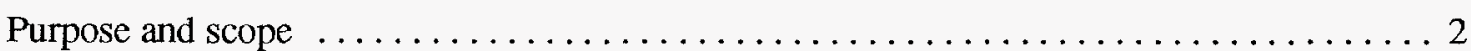

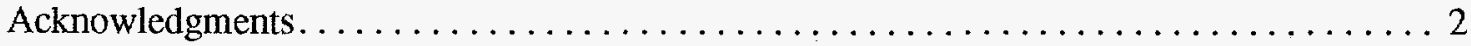

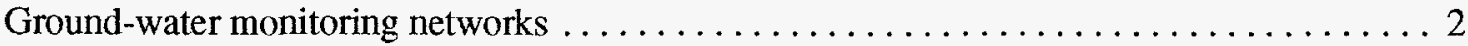

Water-level monitoring network $\ldots \ldots \ldots \ldots \ldots \ldots \ldots \ldots \ldots \ldots \ldots \ldots \ldots \ldots \ldots \ldots \ldots$

Water-quality monitoring network $\ldots \ldots \ldots \ldots \ldots \ldots \ldots \ldots \ldots \ldots \ldots \ldots \ldots \ldots \ldots \ldots$

Guidelines for interpreting results of radiochemical analyses $\ldots \ldots \ldots \ldots \ldots \ldots \ldots \ldots$

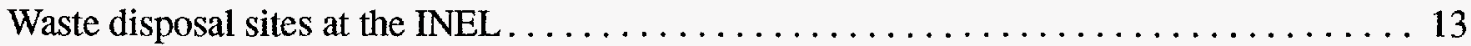

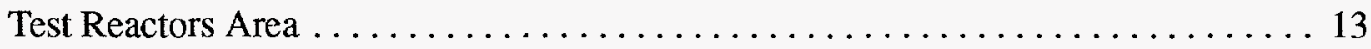

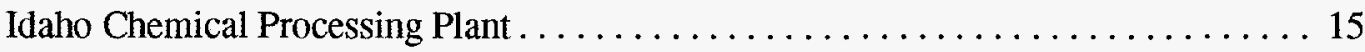

Naval Reactors Facility. . . . . . . . . . . . . . . . . . . . . . . . . 15

Radioactive Waste Management Complex $\ldots \ldots \ldots \ldots \ldots \ldots \ldots \ldots \ldots \ldots$

Test Area North. . . . . . . . . . . . . . . . . . . . . . . . 17

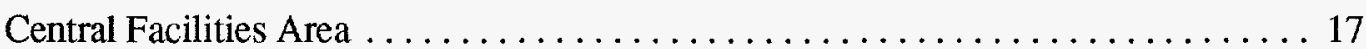

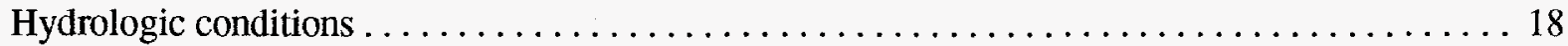

Surface water. . . . . . . . . . . . . . . . . 18

Ground water. . . . . . . . . . . . . . . . . . . . . . 18

Selected radiochemical and chemical constituents in and physical properties of water

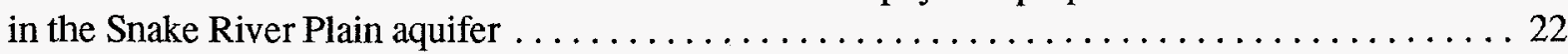

Tritium. . . . . . . . . . . . . . . . . . . . . . . . . . . . . . . 22

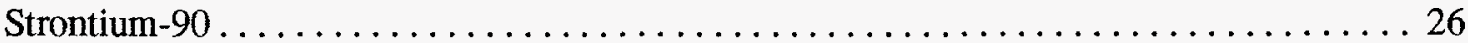

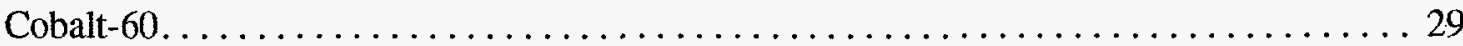

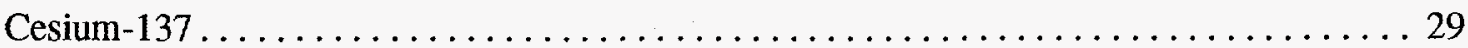

Plutonium . . . . . . . . . . . . . . . . . . . . . . . . . . . . . . . . 29

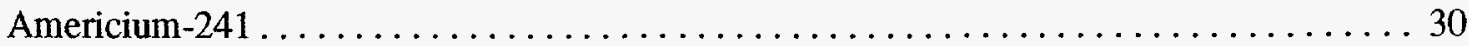

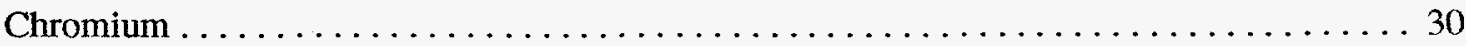

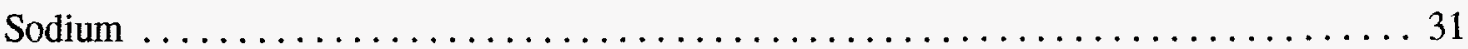

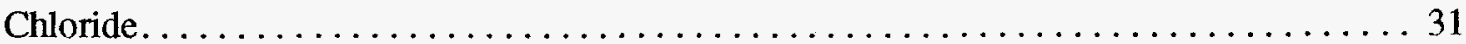

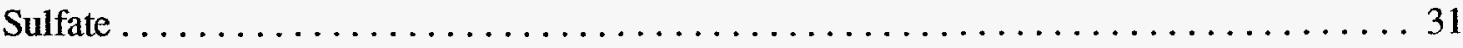

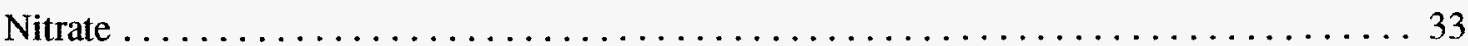

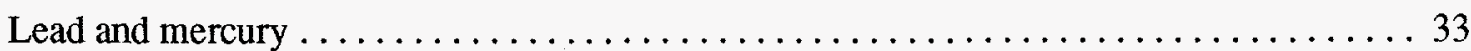

Purgeable organic compounds. . . . . . . . . . . . . . . . . . . . 35

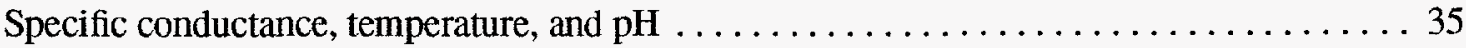

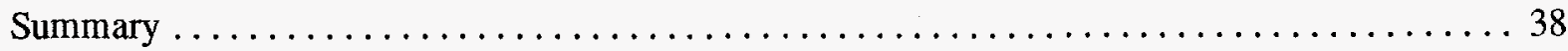

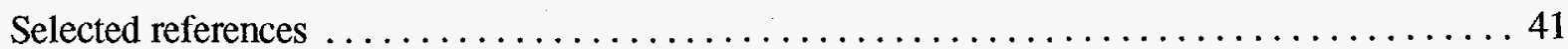




\section{ILLUSTRATIONS}

Figures 1-5. Maps showing:

1. Location of the Idaho National Engineering Laboratory, stream-gaging stations, and and selected facilities. . . . . . . . . . . . . . . . . . . . . . . . . . 3

2. Location of wells and frequency of water-level measurements (as of December 1991) in the Snake River Plain aquifer, Idaho National Engineering Laboratory and vicinity. . . 4

3. Location of wells and frequency of water-level measurements (as of December 1991) in the Snake River Plain aquifer, Test Reactors Area, Idaho Chemical Processing Plant, and Radioactive Waste Management Complex..................... 5

4. Location of wells and frequency of water-sample collections (as of December 1991) in the Snake River Plain aquifer, Idaho National Engineering Laboratory and vicinity. . . 7

5. Location of wells and frequency of water-sample collections (as of December 1991) in the Snake River Plain aquifer, Test Reactors Area, Idaho Chemical Processing Plant, and Radioactive Waste Management Complex ................ 8

6. Graphs showing amount of tritium discharged, tritium as a percentage of total radioactive constituents in wastewater discharged, and volume of wastewater discharged to the radioactive-waste infiltration ponds at the Test Reactors Area, $1960-91$

7. Graphs showing amount of tritium discharged, tritium as a percentage of total radioactive constituents in wastewater discharged, and volume of wastewater discharged to the disposal well and infiltration ponds at the Idaho Chemical

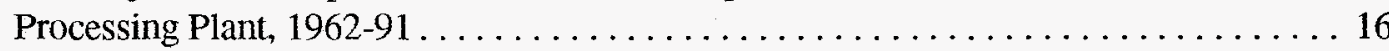

8. Hydrographs showing discharge of the Big Lost River below Mackay Reservoir (water years 1905, 1913-14, and 1920-91), Big Lost River below the INEL diversion near Arco, and the INEL diversion at head near Arco (water years 1965-91) . . . . . 19

9. Map showing altitude of the water table and generalized direction of ground-water flow in the Snake River Plain aquifer in the vicinity of the Idaho National Engineering

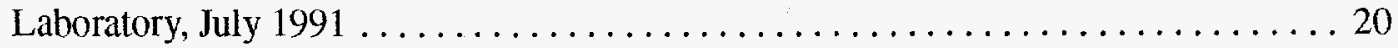

10. Map showing generalized decline in ground-water levels in the Snake River Plain aquifer in the vicinity of the Idaho National Engineering Laboratory, April-August

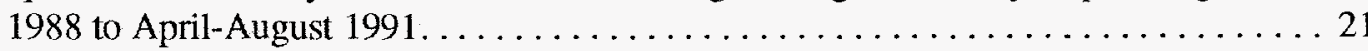

11. Hydrographs showing water levels in four wells in the southwestern part of the Idaho National Engineering Laboratory, $1950-91 \ldots \ldots \ldots \ldots \ldots \ldots \ldots \ldots \ldots \ldots$

Figures 12-17. Maps showing:

12. Distribution of tritium in water from the Snake River Plain aquifer at the Idaho National Engineering Laboratory, October 1991

13. Distribution of strontium-90 in water from the Snake River Plain aquifer at the Idaho National Engineering Laboratory, October 1991

14. Distribution of chloride in water from the Snake River Plain aquifer at the Idaho National Engineering Laboratory, October $1991 \ldots \ldots \ldots \ldots \ldots \ldots \ldots \ldots \ldots$ 
15. Distribution of nitrate in water from the Snake River Plain aquifer at the Idaho National Engineering Laboratory, October $1991 \ldots \ldots \ldots \ldots \ldots \ldots \ldots \ldots \ldots$

16. Distribution of 1,1,1-trichloroethane in water from the Snake River Plain aquifer at the Idaho National Engineering Laboratory, 1987 to $1991 \ldots \ldots \ldots \ldots \ldots \ldots \ldots$

17. Distribution of specific conductance of water from the Snake River Plain aquifer at the Idaho National Engineering Laboratory, October $1991 \ldots \ldots \ldots \ldots \ldots \ldots \ldots$

\section{TABLES}

1. Well location, construction, and sample-collection method and frequency, Snake River Plain aquifer, Idaho National Engineering Laboratory $\ldots \ldots \ldots \ldots \ldots \ldots \ldots \ldots$

2. Tritium concentrations in water from selected wells at the Idaho National Engineering Laboratory, $1980-91$

3. Strontium-90 concentrations in water from selected wells at the Idaho National

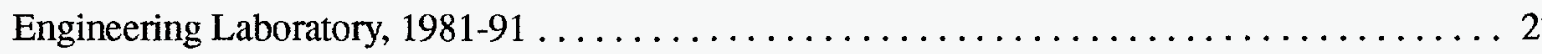

4. Concentrations of 1,1,1-trichloroethane in water from selected wells at the Idaho National Engineering Laboratory, 1987-91

\section{CONVERSION FACTORS, VERTICAL DATUM, AND ABBREVIATED UNITS}

$\begin{array}{lc}\text { Multiply } & \frac{B y}{25.4} \\ \text { inch (in.) } & 0.3048 \\ \text { foot (ft) } & 1.609 \\ \text { mile (mi) } & 0.4047 \\ \text { acre } & 2.590 \\ \left.\text { square mile ( } \mathrm{mi}^{2}\right) & 3.785 \\ \text { gallon (gal) } & 1,233 \\ \text { acre-foot (acre-ft) } & 0.1646 \\ \text { foot per mile }(\mathrm{ft} / \mathrm{mi}) & 0.01760 \\ \text { cubic foot per second per mile }\left(\left(\mathrm{ft}^{3} / \mathrm{s}\right) / \mathrm{mi}\right) & 0.4536 \\ \text { pound }(\mathrm{lb}) & 3.7 \times 10^{10} \\ \text { curie }(\mathrm{Ci}) & 0.037 \\ \text { picocurie per milliliter }(\mathrm{pCi} / \mathrm{mL}) & 0.037 \\ \text { picocurie per liter }(\mathrm{pCi} / \mathrm{L}) & \end{array}$

For temperature, degrees Celsius $\left({ }^{\circ} \mathrm{C}\right)$ may be converted to degrees Fahrenheit $\left({ }^{\circ} \mathrm{F}\right)$ by using the formula ${ }^{\circ} \mathrm{F}=(1.8)\left({ }^{\circ} \mathrm{C}\right)+32$.

Sea level: In this report, "sea level" refers to the National Geodetic Vertical Datum of 1929-a geodetic datum derived from a general adjustment of the first-order level nets of both the United States and Canada, formerly called Sea Level Datum of 1929.

Abbreviated units used in report: microgram per liter $(\mu \mathrm{g} / \mathrm{L})$, milligram per liter $(\mathrm{mg} / \mathrm{L})$, and microsiemens per centimeter at $25^{\circ} \mathrm{C}(\mu \mathrm{S} / \mathrm{cm})$. 


\title{
HYDROLOGIC CONDITIONS AND DISTRIBUTION OF SELECTED RADIOCHEMICAL AND CHEMICAL CONSTITUENTS IN WATER, SNAKE RIVER PLAIN AQUIFER, IDAHO NATIONAL ENGINEERING LABORATORY, IDAHO, 1989 THROUGH 1991
}

\author{
By Roy C. Bartholomay, Brennon R. Orr, Michael J. Liszewski, and Rodger G. Jensen
}

\begin{abstract}
Radiochemical and chemical wastewater discharged since 1952 to infiltration ponds and disposal wells at the Idaho National Engineering Laboratory (INEL) has affected water quality in the Snake River Plain aquifer. The U.S. Geological Survey, in cooperation with the U.S. Department of Energy, maintains a continuous monitoring network at the INEL to determine hydrologic trends and to delineate the movement of radiochemical and chemical wastes in the aquifer. This report presents an analysis of water-level and water-quality data collected from the Snake River Plain aquifer during 1989-91.
\end{abstract}

Water in the eastern Snake River Plain aquifer moves principally through fractures and interflow zones in basalt, generally flows southwestward, and eventually discharges at springs along the Snake River. The aquifer is recharged principally from irrigation water, infiltration of streamflow, and ground-water inflow from adjoining mountain drainage basins. Water levels in wells throughout the INEL generally declined during 1989-91 due to drought.

Detectable concentrations of radiochemical constituents in water samples from wells in the Snake River Plain aquifer at the INEL decreased or remained constant during 1989-91. Decreased concentrations are attributed to reduced rates of radioactive-waste disposal, sorption processes, radioactive decay, and changes in waste-disposal practices. Tritium concentrations in water samples decreased as much as 23.8 picocuries per milliliter (pCi/mL) during 1989-91 and ranged from $0.6 \pm 0.2$ to $41.7 \pm 0.9 \mathrm{pCi} / \mathrm{mL}$ in 1991 . Strontium- 90 concentrations remained constant during 1989-91 and ranged from $9 \pm 3$ to $55 \pm 4$ picocuries per liter in 1991. In 1989, the concentrations of cobalt-60, cesium-137, plutonium-238, and plutonium-239, -240 (undivided) in water samples from one well at the Test Area North were above the reporting level.

Detectable concentrations of chemical constituents in water from the Snake River Plain aquifer at the INEL were variable during 1989-91. Sodium and chloride concentrations in the southern part of the INEL increased slightly during 1989-91 because of increased waste-disposal rates and a lack of recharge from the Big Lost River. Nitrate concentrations remained relatively constant during 1989-91 even though waste-disposal rates decreased. In 1991, water from one well south of the Test Reactors Area contained 200 micrograms per liter $(\mu \mathrm{g} / \mathrm{L})$ of dissolved chromium; other water samples contained from less than 1 to $30 \mu \mathrm{g} / \mathrm{L}$.

During 1987-91, concentrations of at least 1 of 19 purgeable organic compounds were detected in water from wells at the INEL. Plumes of 1,1,1trichloroethane have developed near the Idaho Chemical Processing Plant and the Radioactive Waste Management Complex as a result of wastedisposal practices. 


\section{INTRODUCTION}

The Idaho National Engineering Laboratory (INEL), encompassing about $890 \mathrm{mi}^{2}$ of the eastern Snake River Plain in southeastern Idaho (fig. 1), is operated by the U.S. Department of Energy (DOE). INEL facilities are used in the development of peacetime atomic-energy applications, nuclear safety research, defense programs, and advanced energy concepts. Radiochemical and chemical wastewater generated at these facilities has been discharged to onsite infiltration ponds and disposal wells since 1952. Wastewater disposal has resulted in detectable concentrations of several waste constituents in water from the Snake River Plain aquifer underlying the INEL.

The DOE requires information about the mobility of dilute radiochemical- and chemicalwaste constituents in the Snake River Plain aquifer. Waste-constituent mobility is, in part, determined by (1) the rate and direction of ground-water flow; (2) the locations, quantities, and methods of waste disposal; (3) waste-constituent chemistry; and (4) the geochemical processes taking place in the aquifer. This study was conducted by the U.S. Geological Survey (USGS) in cooperation with the DOE's Idaho Operations Office.

\section{Purpose and Scope}

In 1949, the U.S. Atomic Energy Commission, which later became the DOE, requested that the USGS describe the water resources of the area now known as the INEL. The purpose of the resulting study was to characterize these resources before the development of nuclear-reactor testing facilities. The USGS since has maintained a monitoring network at the INEL to determine hydrologic trends and to delineate the movement of facilityrelated radiochemical and chemical wastes in the Snake River Plain aquifer.

This report presents an analysis of water-level and water-quality data collected from wells in the Snake River Plain aquifer during 1989-91 as part of the continuing hydrogeologic investigation at the INEL. The report describes the distribution and concentration of selected radiochemical and chem- ical constituents in ground water at the INEL. An analysis of water-level and water-quality data collected during 1989-91 from perched groundwater zones in unsaturated rocks overlying the Snake River Plain aquifer will be presented in a separate report. Several reports generated from previous investigations of the geology and hydrology of the area are listed in the references and copies can be obtained at the USGS's Project Office at the INEL.

\section{Acknowledgments}

The DOE's Radiological and Environmental Sciences Laboratory (RESL) provided radiochemical analyses of water samples. Technical staff at the RESL during 1989-91 were under the supervision of T.F. Gesell, Director, and D.B. Martin, Chief, Analytical Chemistry Branch. The authors are grateful for technical review of the manuscript by USGS hydrologists Lisa Senior, Malvern, PA and L. DeWayne Cecil, Idaho Falls, ID.

\section{Ground-Water Monitoring Networks}

Ground-water monitoring networks are maintained at the INEL to characterize the occurrence, movement, and quality of water and to delineate waste-constituent plumes in the Snake River Plain aquifer. These networks consist of wells from which periodic water-level and water-quality data are obtained. Data from the monitoring networks are on file at the USGS's INEL Project Office.

Water-level monitoring network.-The waterlevel network was designed to determine hydraulic-gradient changes that influence the rate and direction of ground-water and wasteconstituent movement in the Snake River Plain aquifer, to identify sources of recharge to the aquifer, and to measure the effects of recharge. Water levels in 131 wells were monitored during 1989-91. Water levels were measured continuously in 3 wells, monthly in 9 wells, quarterly in 61 wells, semiannually in 30 wells, and annually in 28 wells. The location of wells and frequency of water-level measurements as of December 1991 are shown in figures 2 and 3. Water-level data for 


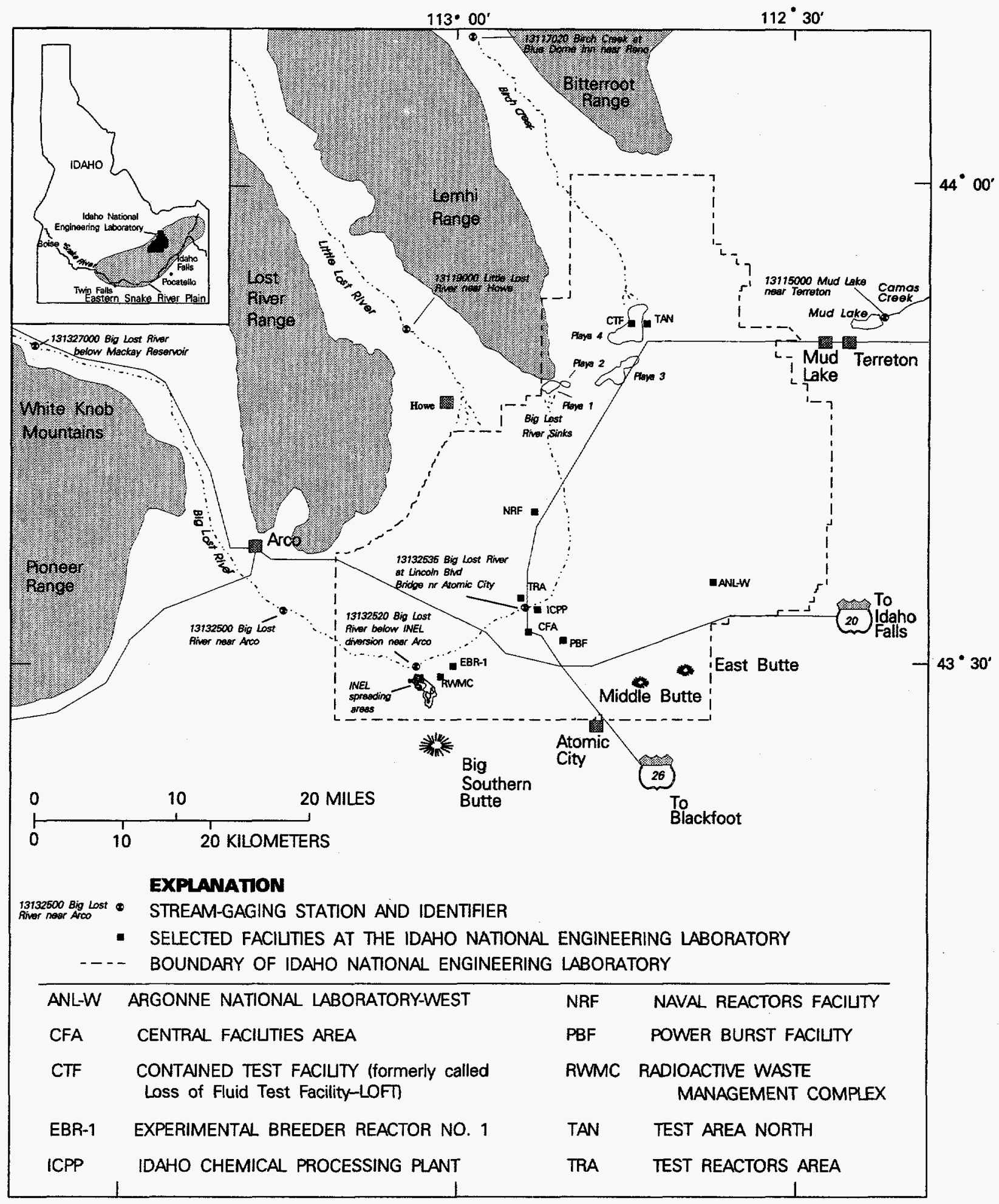

Figure 1. Location of the Idaho National Engineering Laboratory, stream-gaging stations, and selected facilities. 


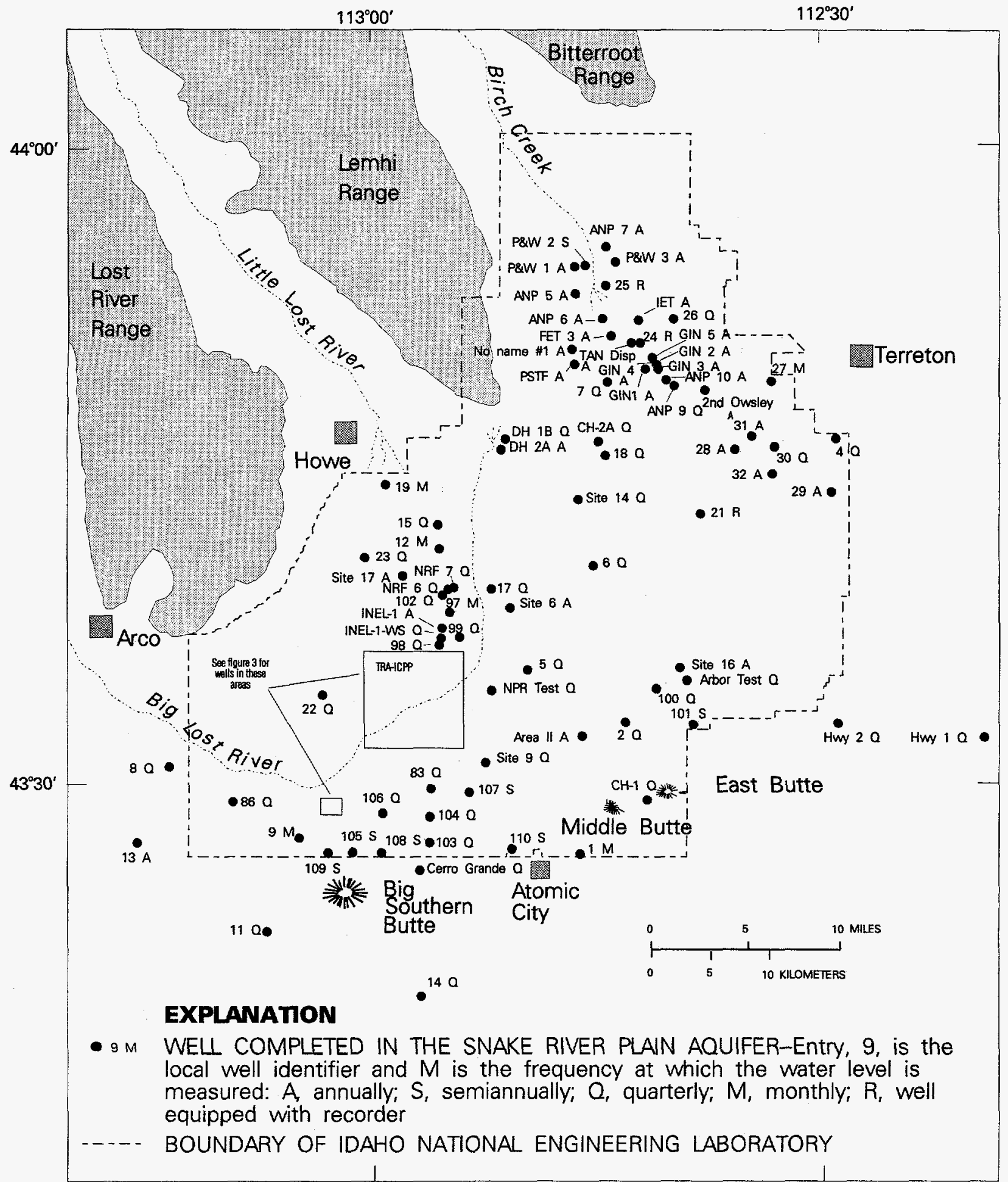

Figure 2. Location of wells and frequency of water-level measurements (as of December 1991) in the Snake River Plain aquifer, Idaho National Engineering Laboratory and vicinity. 

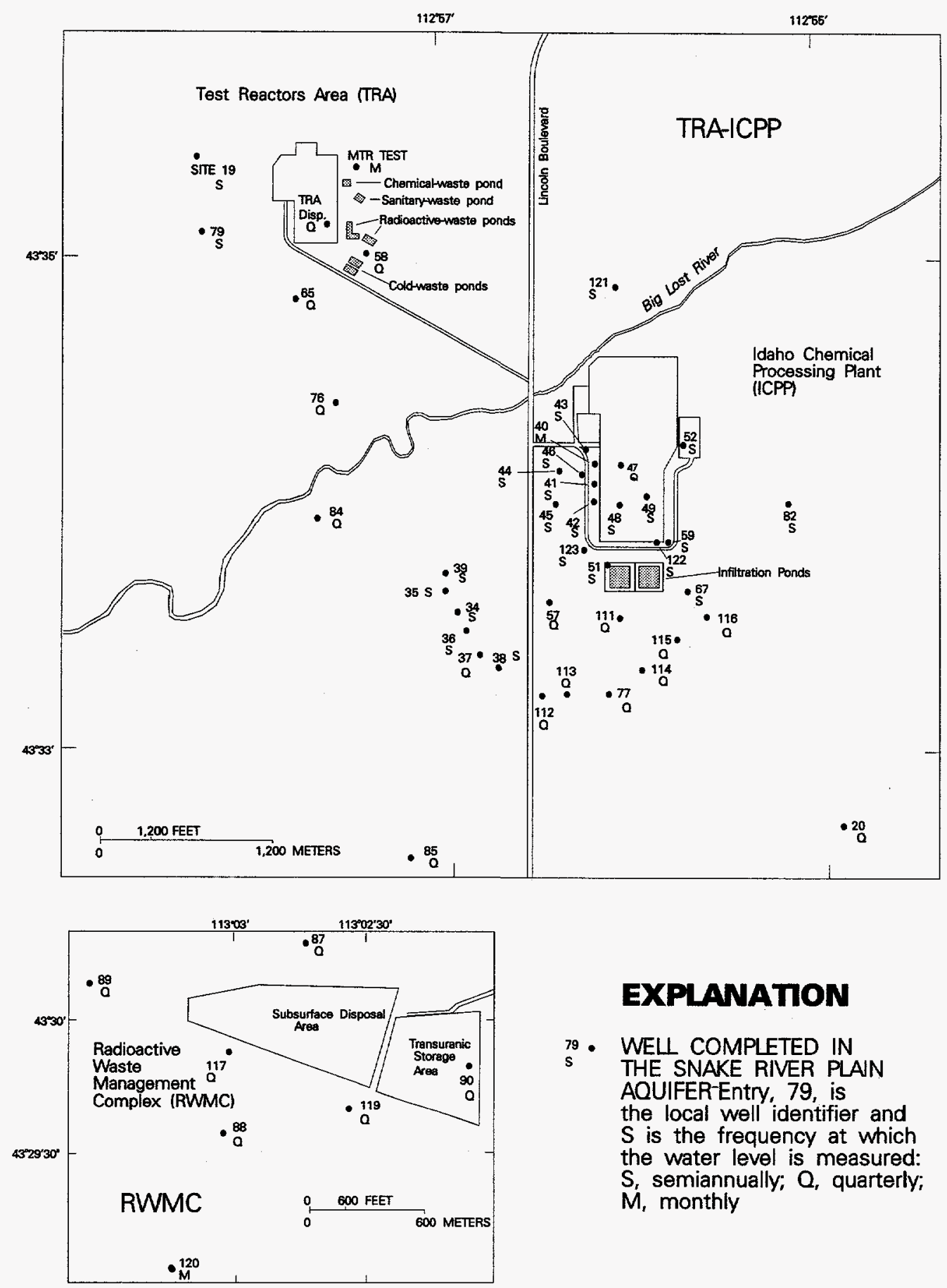

\section{EXPLANATION}

79 - WELL COMPLETED IN THE SNAKE RIVER PLAIN AQUIFER-Entry, 79, is the local well identifier and $S$ is the frequency at which the water level is measured: $\mathrm{S}$, semiannually; $\mathrm{Q}$, quarterly; $M$, monthly

Figure 3. Location of wells and frequency of water-level measurements (as of December 1991) in the Snake River Plain aquifer, Test Reactors Area, Idaho Chemical Processing Plant, and Radioactive Waste Management Complex. 
the wells from 1983 through 1990 are summarized in a report by Ott and others (1992).

Water-quality monitoring network.-The radiochemical and chemical character of water in the Snake River Plain aquifer is determined from analyses of water samples collected as part of a comprehensive sampling program to identify contaminant concentrations and to define the pattern of waste migration in the aquifer. Water samples are analyzed from nearby surface-water sites and from wells in perched ground-water zones to document the chemical quality of water that recharges the aquifer. Numerous water samples are collected near areas of detailed study, such as the Test Reactors Area (TRA), Idaho Chemical Processing Plant (ICPP), Radioactive Waste Management Complex (RWMC), and Test Area North (TAN).

The type, frequency, and depth of ground-water sampling generally depend on the information needed in a specific area. Water samples routinely are collected and analyzed for concentrations of tritium, strontium-90, cobalt- 60 , cesium-137, plutonium-238, the sum of plutonium-239 and plutonium-240 (undivided), americium-241, dissolved and hexavalent chromium, sodium, chloride, nitrate, purgeable organic compounds and measurements of specific conductance, $\mathrm{pH}$ and temperature. Water samples are analyzed for the radiochemical constituents at the RESL at the INEL; water samples are analyzed for chemical constituents at the National Water Quality Laboratory (NWQL) at Arvada, Colo. The location of surface-water sites and wells that constituted the water-quality monitoring network during 1989-91 and the frequency of sample collection are shown in figures 1,4 , and 5 and in table 1 .

The methods used in sampling for selected constituents generally follow the guidelines established by the USGS (Goerlitz and Brown, 1972; Stevens and others, 1975; Wood, 1981; Claassen, 1982; W.L. Bradford, USGS written commun., 1985; Wershaw and others, 1987; and Fishman and Friedman, 1989). Water samples analyzed by the NWQL and RESL are collected in accordance with a quality-assurance plan for quality-of-water activities conducted by personnel at the INEL Project Office. The plan was finalized in June 1989, revised in March 1992, and is available for inspection at the USGS's Project Office at the INEL. In general, about 10 percent of the samples collected are for quality assurance. Quality-assurance samples include blanks, equipment blanks, splits, duplicates, and replicates. A comparative study to determine agreement among analytical results for water-sample pairs analyzed by laboratories involved in the INEL Project Office qualityassurance program is summarized by Wegner (1989). Additional quality-assurance studies by personnel at the INEL Project Office include an evaluation of field-sampling and preservation methods for strontium-90 (Cecil and others, 1989), a comparison of different pump types used for sampling purgeable organic compounds (Knobel and Mann, 1993), and an analysis of tritium and strontium-90 concentrations in water from wells after purging different borehole volumes (Bartholomay, 1993).

\section{Guidelines for Interpreting Results of Radiochemical Analyses}

Concentrations of radionuclides are reported with an estimated sample standard deviation, $\mathbf{s}$, that is obtained by propagating sources of analytical uncertainty in measurements. The following guidelines for interpreting analytical results are based on an extension of a method proposed by Currie (1984).

In the analysis for a particular radionuclide, laboratory measurements are made on a target sample and a prepared blank. Instrument signals for the sample and the blank vary randomly. Therefore, it is essential to distinguish between two key aspects of the problem of detection: (1) the instrument signal for the sample must be larger than the signal observed for the blank before the decision can be made that the radionuclide was detected; and (2) an estimation must be made of the minimum radionuclide concentration that will yield a sufficiently large observed signal before the correct decision can be made for detection or nondetection of the radionuclide. The first aspect of the problem is a qualitative decision based on an observed signal and a definite criterion for detection. The second aspect of the problem is an 


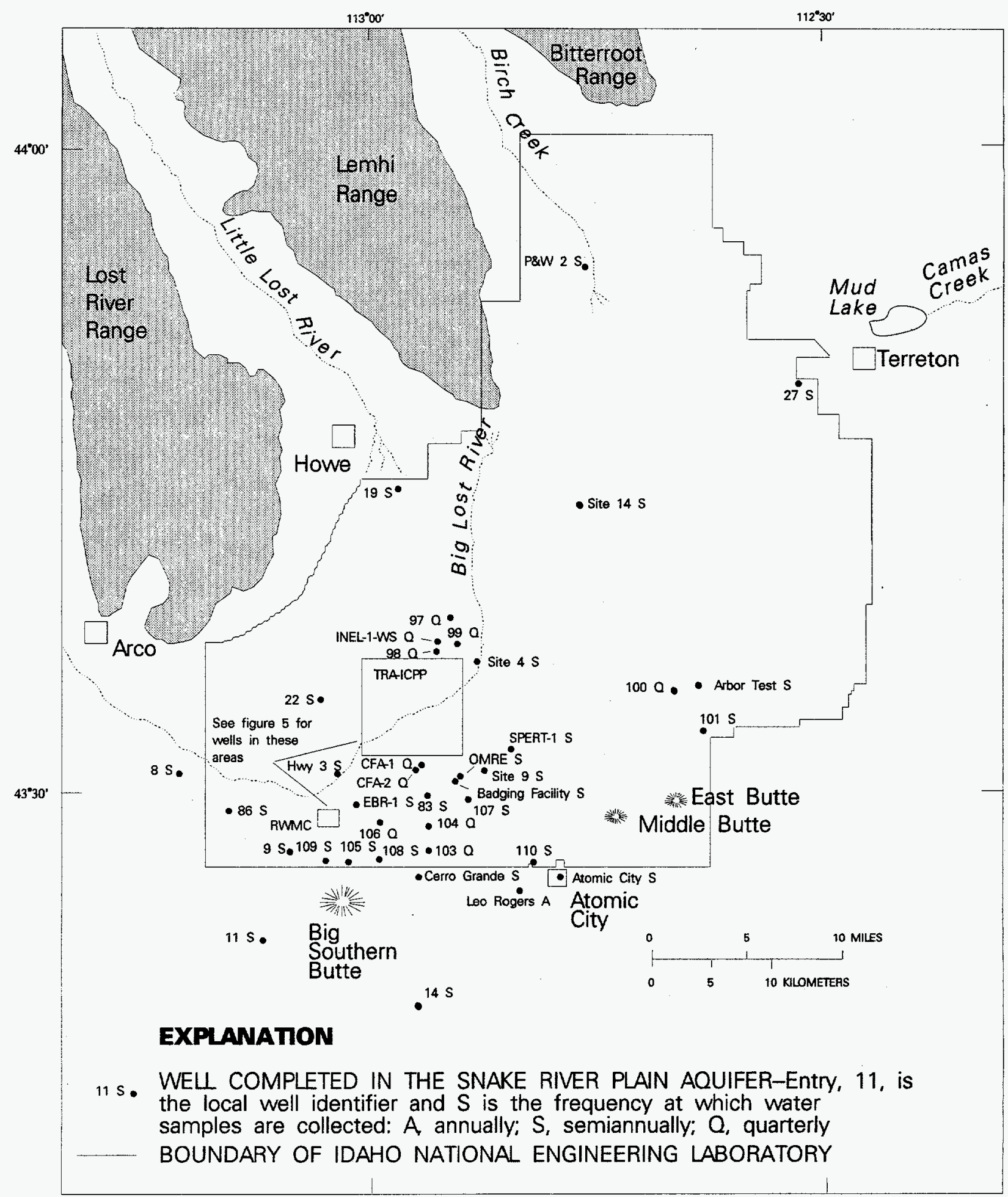

Figure 4. Location of wells and frequency of water-sample collections (as of December 1991) in the Snake River Plain aquifer, Idaho National Engineering Laboratory and vicinity. 


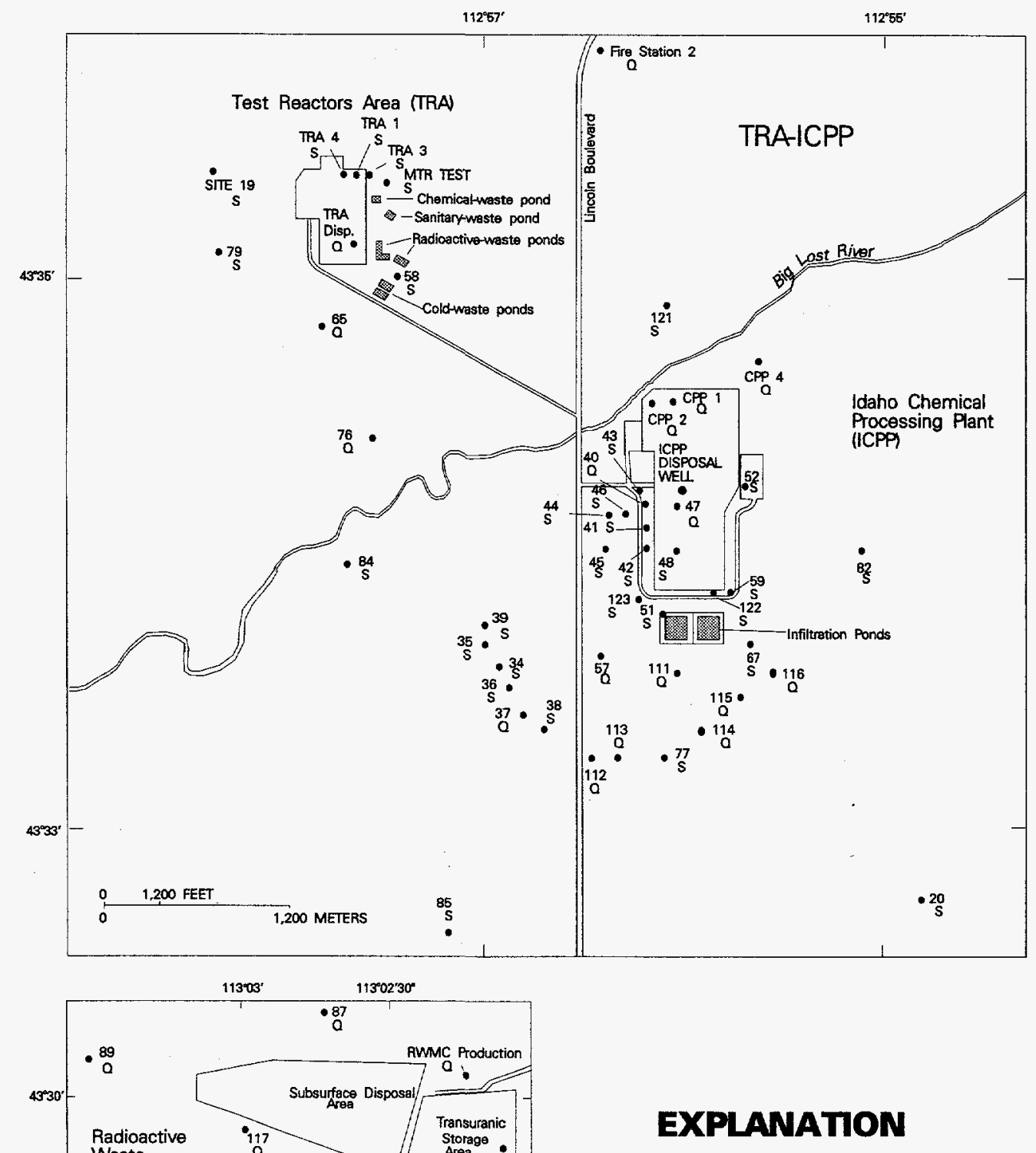

119 - WELL COMPLETED IN THE SNAKE RIVER PLAIN AQUIFER-Entry, 119 , is the local well identifier and $Q$ is the frequency at which water samples are collected: $S$, semiannually; $Q$, quarterly

Figure 5. Location of wells and frequency of water-sample collections (as of December 1991 ) in the Snake River Plain aquifer, Test Reactors Area, Idaho Chemical Processing Plant, and Radioactive Waste Management Complex. 
Table 1. Well location, construction, and sample-collection method and frequency, Snake River Plain aquifer, Idaho National Engineering Laboratory

[Status of wells as of October 1991. Well identifier: see figures 4 and 5 for well locations. Sampling method:

Tap-sampled from faucet; Pump - sampled from pumping well (pumping rate in gallons per minute);

Bail—sampled with a bailer (depth, in feet, at which samples were collected). Sampling frequency: Q—quarterly; S-semiannual; A-annual]

\begin{tabular}{|c|c|c|c|c|c|c|}
\hline \multirow{2}{*}{ Well identifier } & \multicolumn{2}{|c|}{ Location } & \multicolumn{2}{|c|}{ Well construction } & \multicolumn{2}{|c|}{ Water-sample collection } \\
\hline & Latitude & Longitude & $\begin{array}{l}\text { Diameter } \\
\text { (inches) }\end{array}$ & $\begin{array}{c}\text { Depth } \\
\text { (feet) }\end{array}$ & Method & Frequency \\
\hline Arbor Test & $43^{\circ} 35^{\prime} 09^{\prime \prime}$ & $112^{\circ} 38^{\prime} 48^{\prime \prime}$ & 16 & 790 & Pump (16) & $S$ \\
\hline Atomic City & $43^{\circ} 26^{\prime} 38^{\prime \prime}$ & $112^{\circ} 48^{\prime} 41^{\prime \prime}$ & 8 & 639 & Tap & $\mathrm{S}$ \\
\hline Badging Facility & $43^{\circ} 30^{\prime} 42^{\prime \prime}$ & $112^{\circ} 53^{\prime} 51^{\prime \prime}$ & 8 & 644 & Pump (35) & $S$ \\
\hline Cerro Grande & $43^{\circ} 26^{\prime} 18^{\prime \prime}$ & $112^{\circ} 55^{\prime} 55^{\prime \prime}$ & 6 & 567 & Bailer $(560)$ & $\mathbf{S}$ \\
\hline CFA-1 & $43^{\circ} 32^{\prime} 04^{\prime \prime}$ & $112^{\circ} 56^{\prime} 20^{\prime \prime}$ & 16 & 685 & Pump $(1,000)$ & $\mathbf{Q}$ \\
\hline CFA-2 & $43^{\circ} 31^{\prime} 44^{\prime \prime}$ & $112^{\circ} 56^{\prime} 35^{\prime \prime}$ & 20 & 681 & Pump $(1,400)$ & $\mathbf{Q}$ \\
\hline CPP-1 & $43^{\circ} 34^{\prime} 33^{\prime \prime}$ & $112^{\circ} 56^{\prime} 02^{\prime \prime}$ & 20 & 585 & Pump $(3,000)$ & $\mathbf{Q}$ \\
\hline CPP-2 & $43^{\circ} 34^{\prime} 32^{\prime \prime}$ & $112^{\circ} 56^{\prime} 08^{\prime \prime}$ & 16 & 605 & Pump $(3,000)$ & $\mathrm{Q}$ \\
\hline CPP-4 & $43^{\circ} 34^{\prime} 40^{\prime \prime}$ & $112^{\circ} 55^{\prime} 44^{\prime \prime}$ & 16 & 700 & Pump (400) & Q \\
\hline EBR-1 & $43^{\circ} 30^{\prime} 51^{\prime \prime}$ & $113^{\circ} 00^{\prime} 26^{\prime \prime}$ & 12 & 1,075 & Pump $(1,000)$ & $\mathbf{S}$ \\
\hline Fire Station 2 & $43^{\circ} 35^{\prime} 48^{\prime \prime}$ & $112^{\circ} 56^{\prime} 23^{\prime \prime}$ & 16 & 518 & Pump (400) & $\mathrm{Q}$ \\
\hline Hwy 3 & $43^{\circ} 32^{\prime} 56^{\prime \prime}$ & $113^{\circ} 00^{\prime} 25^{\prime \prime}$ & 8 & 750 & Tap & $\mathrm{S}$ \\
\hline INEL-1-WS & $43^{\circ} 37^{\prime} 16^{\prime \prime}$ & $112^{\circ} 56^{\prime} 36^{\prime \prime}$ & 8 & 595 & Pump (30) & $Q$ \\
\hline Leo Rogers & $43^{\circ} 25^{\prime} 33^{\prime \prime}$ & $112^{\circ} 50^{\prime} 49^{\prime \prime}$ & 20 & 702 & $\begin{array}{l}\text { Pump } \\
\text { (unknown) }\end{array}$ & A \\
\hline MTR Test & $43^{\circ} 35^{\prime} 20^{\prime \prime}$ & $112^{\circ} 57^{\prime} 26^{\prime \prime}$ & 8 & 588 & Pump (26) & $S$ \\
\hline OMRE & $43^{\circ} 31^{\prime} 16^{\prime \prime}$ & $112^{\circ} 53^{\prime} 47^{\prime \prime}$ & 14 & 943 & Pump (10) & $\mathrm{S}$ \\
\hline P\&W 2 & $43^{\circ} 54^{\prime} 19^{\prime \prime}$ & $112^{\circ} 45^{\prime} 31^{\prime \prime}$ & 10 & 386 & Pump (35) & $\mathbf{S}$ \\
\hline RWMC Production & $43^{\circ} 30^{\prime} 02^{\prime \prime}$ & $113^{\circ} 02^{\prime} 17^{\prime \prime}$ & 16 & 683 & Pump (200) & $\mathbf{Q}$ \\
\hline Site 4 & $43^{\circ} 36^{\prime} 17^{\prime \prime}$ & $112^{\circ} 54^{\prime} 20^{\prime \prime}$ & 15 & 496 & Pump (500) & $\mathbf{S}$ \\
\hline Site 9 & $43^{\circ} 31^{\prime} 23^{\prime \prime}$ & $112^{\circ} 53^{\prime} 01^{\prime \prime}$ & 10 & 1,057 & Pump (25) & $S$ \\
\hline Site 14 & $43^{\circ} 43^{\prime} 34^{\prime \prime}$ & $112^{\circ} 46^{\prime} 31^{\prime \prime}$ & 10 & 717 & Pump (11) & $\mathrm{S}$ \\
\hline Site 19 & $43^{\circ} 35^{\prime} 22^{\prime \prime}$ & $112^{\circ} 58^{\prime} 21^{\prime \prime}$ & 12 & 865 & Pump (25) & $\mathbf{S}$ \\
\hline SPERT-1 & $43^{\circ} 32^{\prime} 52^{\prime \prime}$ & $112^{\circ} 52^{\prime} 03^{\prime \prime}$ & 24 & 653 & Pump (400) & $\mathbf{S}$ \\
\hline TRA 1 & $43^{\circ} 35^{\prime} 21^{\prime \prime}$ & $112^{\circ} 57^{\prime} 38^{\prime \prime}$ & 20 & 600 & Pump $(3,400)$ & $\mathbf{S}$ \\
\hline
\end{tabular}


Table 1. Well location, construction, and sample-collection method and frequency, Snake River Plain aquifer, Idaho National Engineering Laboratory-continued

\begin{tabular}{|c|c|c|c|c|c|c|}
\hline \multirow{2}{*}{ Well identifier } & \multicolumn{2}{|c|}{ Location } & \multicolumn{2}{|c|}{ Well construction } & \multicolumn{2}{|c|}{ Water-sample collection } \\
\hline & Latitude & Longitude & $\begin{array}{l}\text { Diameter } \\
\text { (inches) }\end{array}$ & $\begin{array}{l}\text { Depth } \\
\text { (feet) }\end{array}$ & Method & Frequency \\
\hline TRA 3 & $43^{\circ} 35^{\prime} 22^{\prime \prime}$ & $112^{\circ} 57^{\prime} 35^{\prime \prime}$ & 20 & 602 & Pump $(3,800)$ & $\mathbf{S}$ \\
\hline TRA 4 & $43^{\circ} 35^{\prime} 21^{\prime \prime}$ & $112^{\circ} 57^{\prime} 42^{\prime \prime}$ & 20 & 975 & Pump $(2,000)$ & $S$ \\
\hline TRA Disposal & $43^{\circ} 35^{\prime} 06^{\prime \prime}$ & $112^{\circ} 57^{\prime} 23^{\prime \prime}$ & 12 & 1,267 & Pump (25) & $\mathbf{Q}$ \\
\hline USGS 8 & $43^{\circ} 31^{\prime} 21^{\prime \prime}$ & $113^{\circ} 11^{\prime} 58^{\prime \prime}$ & 6 & 812 & Pump (16) & $\mathbf{S}$ \\
\hline USGS 9 & $43^{\circ} 27^{\prime} 40^{\prime \prime}$ & $113^{\circ} 04^{\prime} 45^{\prime \prime}$ & 8 & 655 & Pump (19) & $S$ \\
\hline USGS 11 & $43^{\circ} 23^{\prime} 36^{\prime \prime}$ & $113^{\circ} 06^{\prime} 42^{\prime \prime}$ & 12 & 704 & Pump (17) & $S$ \\
\hline USGS 14 & $43^{\circ} 20^{\prime} 19^{\prime \prime}$ & $112^{\circ} 56^{\prime} 32^{\prime \prime}$ & 6 & 751 & Pump (16) & $S$ \\
\hline USGS 19 & $43^{\circ} 44^{\prime} 26^{\prime \prime}$ & $112^{\circ} 57^{\prime} 57^{\prime \prime}$ & 6 & 405 & Pump (33) & $\mathbf{S}$ \\
\hline USGS 20 & $43^{\circ} 32^{\prime} 53^{\prime \prime}$ & $112^{\circ} 54^{\prime} 59^{\prime \prime}$ & 6 & 676 & Pump (25) & $S$ \\
\hline USGS 22 & $43^{\circ} 34^{\prime} 22^{\prime \prime}$ & $113^{\circ} 03^{\prime} 17^{\prime \prime}$ & 6 & 657 & Pump (2.5) & $\mathbf{S}$ \\
\hline USGS 27 & $43^{\circ} 48^{\prime} 51^{\prime \prime}$ & $112^{\circ} 32^{\prime} 18^{\prime \prime}$ & 8 & 312 & Pump (20) & $\mathbf{S}$ \\
\hline USGS 34 & $43^{\circ} 33^{\prime} 34^{\prime \prime}$ & $112^{\circ} 56^{\prime} 55^{\prime \prime}$ & 10 & 700 & Pump (25) & $\mathbf{S}$ \\
\hline USGS 35 & $43^{\circ} 33^{\prime} 39^{\prime \prime}$ & $112^{\circ} 56^{\prime} 58^{\prime \prime}$ & 7 & 578 & Pump (25) & $\mathbf{S}$ \\
\hline USGS 36 & $43^{\circ} 33^{\prime} 30^{\prime \prime}$ & $112^{\circ} 56^{\prime} 52^{\prime \prime}$ & 6 & 567 & Pump (25) & $\mathbf{S}$ \\
\hline USGS 37 & $43^{\circ} 33^{\prime} 26^{\prime \prime}$ & $112^{\circ} 56^{\prime} 48^{\prime \prime}$ & 8 & 573 & Pump (8) & $Q$ \\
\hline USGS 38 & $43^{\circ} 33^{\prime} 22^{\prime \prime}$ & $112^{\circ} 56^{\circ} 43^{\prime \prime}$ & 8 & 729 & Pump (6) & $S$ \\
\hline USGS 39 & $43^{\circ} 30^{\prime} 42^{\prime \prime}$ & $112^{\circ} 53^{\prime} 51^{\prime \prime}$ & 6 & 572 & Pump (25) & $\mathbf{S}$ \\
\hline USGS 40 & $43^{\circ} 34^{\prime} 11^{\prime \prime}$ & $112^{\circ} 56^{\prime} 11^{\prime \prime}$ & 6 & 483 & Pump (8) & $\mathbf{Q}$ \\
\hline USGS 41 & $43^{\circ} 34^{\prime} 09^{\prime \prime}$ & $112^{\circ} 56^{\prime} 13^{\prime \prime}$ & 6 & 674 & Pump (25) & $\mathbf{S}$ \\
\hline USGS 42 & $43^{\circ} 34^{\prime} 04^{\prime \prime}$ & $112^{\circ} 56^{\prime} 13^{\prime \prime}$ & 6 & 678 & Pump (25) & $S$ \\
\hline USGS 43 & $43^{\circ} 34^{\prime} 15^{\prime \prime}$ & $112^{\circ} 56^{\prime} 15^{\prime \prime}$ & 6 & 676 & Pump (8) & $\mathbf{S}$ \\
\hline USGS 44 & $43^{\circ} 34^{\prime} 09^{\prime \prime}$ & $112^{\circ} 56^{\prime} 21^{\prime \prime}$ & 6 & 650 & Pump (24) & $S$ \\
\hline USGS 45 & $43^{\circ} 34^{\prime} 02^{\prime \prime}$ & $112^{\circ} 56^{\prime} 18^{\prime \prime}$ & 6 & 651 & Pump (24) & $S$ \\
\hline USGS 46 & $43^{\circ} 34^{\prime} 07^{\prime \prime}$ & $112^{\circ} 56^{\prime} 15^{\prime \prime}$ & 6 & 651 & Pump (24) & $S$ \\
\hline USGS 47 & $43^{\circ} 34^{\prime} 07^{\prime \prime}$ & $112^{\circ} 56^{\prime} 03^{\prime \prime}$ & 6 & 652 & Pump (6) & $Q$ \\
\hline USGS 48 & $43^{\circ} 34^{\prime} 01^{\prime \prime}$ & $112^{\circ} 56^{\prime} 03^{\prime \prime}$ & 6 & 750 & Pump (24) & $\mathbf{S}$ \\
\hline USGS 51 & $43^{\circ} 33^{\prime} 50^{\prime \prime}$ & $112^{\circ} 56^{\prime} 06^{\prime \prime}$ & 6 & 659 & Pump (6) & $S$ \\
\hline
\end{tabular}


Table 1. Well location, construction, and sample-collection method and frequency, Snake River Plain aquifer, Idaho National Engineering Laboratory-continued

\begin{tabular}{|c|c|c|c|c|c|c|}
\hline \multirow{2}{*}{ Well identifier } & \multicolumn{2}{|c|}{ Location } & \multicolumn{2}{|c|}{ Well construction } & \multicolumn{2}{|c|}{ Water-sample collection } \\
\hline & Latitude & Longitude & $\begin{array}{l}\text { Diameter } \\
\text { (inches) }\end{array}$ & $\begin{array}{l}\text { Depth } \\
\text { (feet) }\end{array}$ & Method & Frequency \\
\hline USGS 52 & $43^{\circ} 34^{\prime} 14^{\prime \prime}$ & $112^{\circ} 55^{\prime} 42^{\prime \prime}$ & 6 & 650 & Pump (25) & $S$ \\
\hline USGS 57 & $43^{\circ} 33^{\prime} 44^{\prime \prime}$ & $112^{\circ} 56^{\prime} 26^{\prime \prime}$ & 6 & 732 & Pump (5) & $Q$ \\
\hline USGS 58 & $43^{\circ} 35^{\prime} 00^{\prime \prime}$ & $112^{\circ} 57^{\prime} 25^{\prime \prime}$ & 6 & 503 & Pump (25) & $S$ \\
\hline USGS 59 & $43^{\circ} 33^{\prime} 54^{\prime \prime}$ & $112^{\circ} 55^{\prime} 47^{\prime \prime}$ & 6 & 657 & Pump (6) & $\mathbf{S}$ \\
\hline USGS 65 & $43^{\circ} 34^{\prime} 37^{\prime \prime}$ & $112^{\circ} 57^{\prime} 45^{\prime \prime}$ & 6 & 498 & Pump (8) & $\mathbf{Q}$ \\
\hline USGS 67 & $43^{\circ} 33^{\prime} 44^{\prime \prime}$ & $112^{\circ} 55^{\prime} 41^{\prime \prime}$ & 6 & 698 & Pump (8) & $\mathbf{S}$ \\
\hline USGS 76 & $43^{\circ} 34^{\prime} 25^{\prime \prime}$ & $112^{\circ} 57^{\prime} 32^{\prime \prime}$ & 6 & 718 & Pump (25) & Q \\
\hline USGS 77 & $43^{\circ} 33^{\prime} 15^{\prime \prime}$ & $112^{\circ} 56^{\prime} 03^{\prime \prime}$ & 6 & 610 & Pump (25) & $S$ \\
\hline USGS 79 & $43^{\circ} 35^{\prime} 05^{\prime \prime}$ & $112^{\circ} 58^{\prime} 19^{\prime \prime}$ & 6 & 702 & Pump (25) & $S$ \\
\hline USGS 82 & $43^{\circ} 34^{\prime} 01^{\prime \prime}$ & $112^{\circ} 55^{\prime} 10^{\prime \prime}$ & 8 & 700 & Pump (6) & $S$ \\
\hline USGS 83 & $43^{\circ} 30^{\prime} 23^{\prime \prime}$ & $112^{\circ} 56^{\prime} 15^{\prime \prime}$ & 6 & 752 & Pump (6) & $S$ \\
\hline USGS 84 & $43^{\circ} 33^{\prime} 56^{\prime \prime}$ & $112^{\circ} 57^{\prime} 42^{\prime \prime}$ & 6 & 505 & Bail (490) & $\mathrm{S}$ \\
\hline USGS 85 & $43^{\circ} 32^{\prime} 46^{\prime \prime}$ & $112^{\circ} 57^{\prime} 12^{\prime \prime}$ & 6 & 637 & Pump (23) & $S$ \\
\hline USGS 86 & $43^{\circ} 29^{\prime} 35^{\prime \prime}$ & $113^{\circ} 08^{\prime} 00^{\prime \prime}$ & 8 & 691 & Pump (19) & $S$ \\
\hline USGS 87 & $43^{\circ} 30^{\prime} 13^{\prime \prime}$ & $113^{\circ} 02^{\prime} 42^{\prime \prime}$ & 6 & 673 & Pump (3) & $\mathrm{Q}$ \\
\hline USGS 88 & $43^{\circ} 29^{\prime} 40^{\prime \prime}$ & $113^{\circ} 03^{\prime} 02^{\prime \prime}$ & 6 & 662 & Pump (5) & $Q$ \\
\hline USGS 89 & $43^{\circ} 30^{\prime} 05^{\prime \prime}$ & $113^{\circ} 03^{\prime} 28^{\prime \prime}$ & 6 & 646 & Pump (5) & $\mathrm{Q}$ \\
\hline USGS 90 & $43^{\circ} 29^{\prime} 54^{\prime \prime}$ & $113^{\circ} 02^{\prime} 05^{\prime \prime}$ & 6 & 626 & Pump (4) & $\mathrm{Q}$ \\
\hline USGS 97 & $43^{\circ} 38^{\prime} 07^{\prime \prime}$ & $112^{\circ} 55^{\prime} 15^{\prime \prime}$ & 4 & 510 & Pump (27) & $\mathrm{Q}$ \\
\hline USGS 98 & $43^{\circ} 36^{\prime} 57^{\prime \prime}$ & $112^{\circ} 56^{\prime} 36^{\prime \prime}$ & 6 & 505 & Pump (18) & $\mathrm{Q}$ \\
\hline USGS 99 & $43^{\circ} 37^{\prime} 05^{\prime \prime}$ & $112^{\circ} 55^{\prime} 21^{\prime \prime}$ & 6 & 450 & Pump (25) & $\mathrm{Q}$ \\
\hline USGS 100 & $43^{\circ} 35^{\prime} 03^{\prime \prime}$ & $112^{\circ} 40^{\prime} 07^{\prime \prime}$ & 6 & 750 & Pump (18) & $Q$ \\
\hline USGS 101 & $43^{\circ} 32^{\prime} 55^{\prime \prime}$ & $112^{\circ} 38^{\prime} 18^{\prime \prime}$ & 6 & 865 & Pump (9) & $\mathrm{S}$ \\
\hline USGS 103 & $43^{\circ} 27^{\prime} 14^{\prime \prime}$ & $112^{\circ} 56^{\prime} 07^{\prime \prime}$ & 8 & 760 & Pump (21) & $\mathrm{Q}$ \\
\hline USGS 104 & $43^{\circ} 28^{\prime} 56^{\prime \prime}$ & $112^{\circ} 56^{\prime} 08^{\prime \prime}$ & 8 & 700 & Pump (16) & Q \\
\hline USGS 105 & $43^{\circ} 27^{\prime} 03^{\prime \prime}$ & $113^{\circ} 00^{\prime} 18^{\prime \prime}$ & 8 & 800 & Pump (19) & $S$ \\
\hline USGS 106 & $43^{\circ} 29^{\prime} 59^{\prime \prime}$ & $112^{\circ} 59^{\prime} 31^{\prime \prime}$ & 8 & 760 & Pump (22) & $\mathrm{Q}$ \\
\hline
\end{tabular}


Table 1. Well location, construction, and sample-collection method and frequency, Snake River Plain aquifer, Idaho National Engineering Laboratory-continued

\begin{tabular}{|c|c|c|c|c|c|c|}
\hline \multirow{2}{*}{ Well identifier } & \multicolumn{2}{|c|}{ Location } & \multicolumn{2}{|c|}{ Well construction } & \multicolumn{2}{|c|}{ Water-sample collection } \\
\hline & Latitude & Longitude & $\begin{array}{l}\text { Diameter } \\
\text { (inches) }\end{array}$ & $\begin{array}{l}\text { Depth } \\
\text { (feet) }\end{array}$ & Method & Frequency \\
\hline USGS 107 & $43^{\circ} 29^{\prime} 42^{\prime \prime}$ & $112^{\circ} 53^{\prime} 28^{\prime \prime}$ & 8 & 690 & Pump (5) & $S$ \\
\hline USGS 108 & $43^{\circ} 26^{\prime} 59^{\prime \prime}$ & $112^{\circ} 58^{\prime} 26^{\prime \prime}$ & 8 & 760 & Pump (20) & $S$ \\
\hline USGS 109 & $43^{\circ} 27^{\prime} 01^{\prime \prime}$ & $113^{\circ} 02^{\prime} 56^{\prime \prime}$ & 6 & 800 & Pump (16) & $S$ \\
\hline USGS 110 & $43^{\circ} 27^{\prime} 17^{\prime \prime}$ & $112^{\circ} 50^{\prime} 15^{\prime \prime}$ & 8 & 780 & Pump (5) & $S$ \\
\hline USGS 111 & $43^{\circ} 33^{\prime} 31^{\prime \prime}$ & $112^{\circ} 56^{\prime} 05^{\prime \prime}$ & 8 & 595 & Pump (15) & $Q$ \\
\hline USGS 112 & $43^{\circ} 33^{\prime} 14^{\prime \prime}$ & $112^{\circ} 56^{\prime} 30^{\prime \prime}$ & 8 & 563 & Pump (25) & $Q$ \\
\hline USGS 113 & $43^{\circ} 33^{\prime} 14^{\prime \prime}$ & $112^{\circ} 56^{\prime} 18^{\prime \prime}$ & 6 & 564 & Pump (25) & $Q$ \\
\hline USGS 114 & $43^{\circ} 33^{\prime} 18^{\prime \prime}$ & $112^{\circ} 55^{\prime} 50^{\prime \prime}$ & 6 & 562 & Pump (10) & $Q$ \\
\hline USGS 115 & $43^{\circ} 32^{\prime} 20^{\prime \prime}$ & $112^{\circ} 55^{\prime} 41^{\prime \prime}$ & 6 & 581 & Pump (15) & Q \\
\hline USGS 116 & $43^{\circ} 33^{\prime} 31^{\prime \prime}$ & $112^{\circ} 55^{\prime} 32^{\prime \prime}$ & 6 & 580 & Pump (20) & $\mathrm{Q}$ \\
\hline USGS 117 & $43^{\circ} 29^{\prime} 55^{\prime \prime}$ & $113^{\circ} 02^{\prime} 59^{\prime \prime}$ & 8 & 655 & Pump (5) & $\mathrm{Q}$ \\
\hline USGS 119 & $43^{\circ} 29^{\prime} 45^{\prime \prime}$ & $113^{\circ} 02^{\prime} 34^{\prime \prime}$ & 8 & 705 & Pump (3) & $\mathrm{Q}$ \\
\hline USGS 120 & $43^{\circ} 29^{\prime} 19^{\prime \prime}$ & $113^{\circ} 03^{\prime} 15^{\prime \prime}$ & 8 & 705 & Pump (20) & $Q$ \\
\hline USGS 121 & $43^{\circ} 34^{\prime} 50^{\prime \prime}$ & $112^{\circ} 56^{\prime} 03^{\prime \prime}$ & 8 & 475 & Pump (2) & $S$ \\
\hline USGS 122 & $43^{\circ} 33^{\prime} 53^{\prime \prime}$ & $112^{\circ} 55^{\prime} 52^{\prime \prime}$ & 4 & 480 & Pump (2.5) & $S$ \\
\hline USGS 123 & $43^{\circ} 33^{\prime} 52^{\prime \prime}$ & $112^{\circ} 56^{\prime} 14^{\prime \prime}$ & 8 & 481 & Pump (3) & $S$ \\
\hline
\end{tabular}


estimation of the detection capabilities of a given measurement process.

In the laboratory, instrument signals must exceed a critical level of $1.6 \mathrm{~s}$ before the qualitative decision can be made as to whether the radionuclide was detected. At $1.6 \mathrm{~s}$, there is about a 95-percent probability that the correct conclusion-not detected - will be made. Given a large number of samples, as many as 5 percent of the samples with measured concentrations larger than or equal to $1.6 \mathrm{~s}$, which were concluded as being detected, might not contain the radionuclide. These measurements are referred to as false positives and are errors of the first kind in hypothesis testing.

Once the critical level of $1.6 \mathrm{~s}$ has been defined, the minimum detectable concentration may be determined. Concentrations that equal 3 s represent a measurement at the minimum detectable concentration. For true concentrations of $3 \mathrm{~s}$ or larger, there is a 95-percent or larger probability that the radionuclide was detected in a sample. In a large number of samples, the conclusion-not detected - will be made in 5 percent of the samples that contain true concentrations at the minimum detectable concentration of $3 \mathrm{~s}$. These measurements are referred to as false negatives and are errors of the second kind in hypothesis testing.

True radionuclide concentrations between $1.6 \mathrm{~s}$ and $3 \mathrm{~s}$ have larger errors of the second kind. That is, there is a larger-than-5-percent probability of false negative results for samples with true concentrations between $1.6 \mathrm{~s}$ and $3 \mathrm{~s}$. Although the radionuclide might have been detected, such detection may not be considered reliable; at $1.6 \mathrm{~s}$, the probability of a false negative is about 50 percent.

The critical level and minimum detectable concentration are based on counting statistics alone and do not include systematic or random errors inherent in laboratory procedures. The values $1.6 \mathrm{~s}$ and $3 s$ vary slightly with background or blank counts, with the number of gross counts for individual analyses, and for different radionuclides. In this report, radionuclide concentrations less than $3 \mathrm{~s}$ are considered to be below a "reporting level." The critical level, minimum detectable concentration, and reporting level aid the reader in the interpreta- tion of analytical results and do not represent absolute concentrations of radioactivity which may or may not have been detected.

\section{Waste-Disposal Sites at the INEL}

Wastewater disposal sites at INEL facilities have been the principal sources of radioactive- and chemical-waste constituents in water from the Snake River Plain aquifer. In the past, wastewater disposal sites at the INEL have included infiltration ponds and ditches, drain fields, and disposal wells. From 1989 to 1991, wastewater was discharged into infiltration ponds and drain fields. Waste materials buried at the RWMC (fig. 1) also are a source of some constituents in ground water. Radioactive-waste-disposal data presented in this report were obtained from a series of radioactive waste-management information reports (Litteer and Reagen, 1990; Litteer and others, 1991b; Litteer and others, 1993). Chemical-waste-disposal data were obtained from a series of industrial waste-management information reports (Litteer and Peterson, 1990; Litteer and others, 1991a; D.L. Litteer, written commun., 1993). The radioactiveand chemical-waste-disposal data are collected by contractors at each facility.

Test Reactors Area.--Since 1959, low-level radioactive, chemical, and sanitary wastewater has been discharged to infiltration ponds. Coolingtower wastewater was discharged to radioactivewaste infiltration ponds from 1952 to 1964 , to the Snake River Plain aquifer through a 1,275-ft-deep disposal well (TRA Disp., fig. 3) from 1964 until March 1982, and into two cold-waste infiltration ponds from 1982 to the present. During 1989-91, about $354 \mathrm{million}$ gal/yr of wastewater was discharged to infiltration ponds at the TRA (fig. 3).

The average annual discharge to the radioactive-waste infiltration ponds was about 139 million gal during 1960-91 (fig. 3). The volume of wastewater and the amount of tritium discharged to the radioactive-waste infiltration ponds during this period are shown in figure 6 . The volume of wastewater discharged to the infiltration ponds was 18.3 million gal in 1988 and 28.7 million gal in 1991. The average annual discharge 

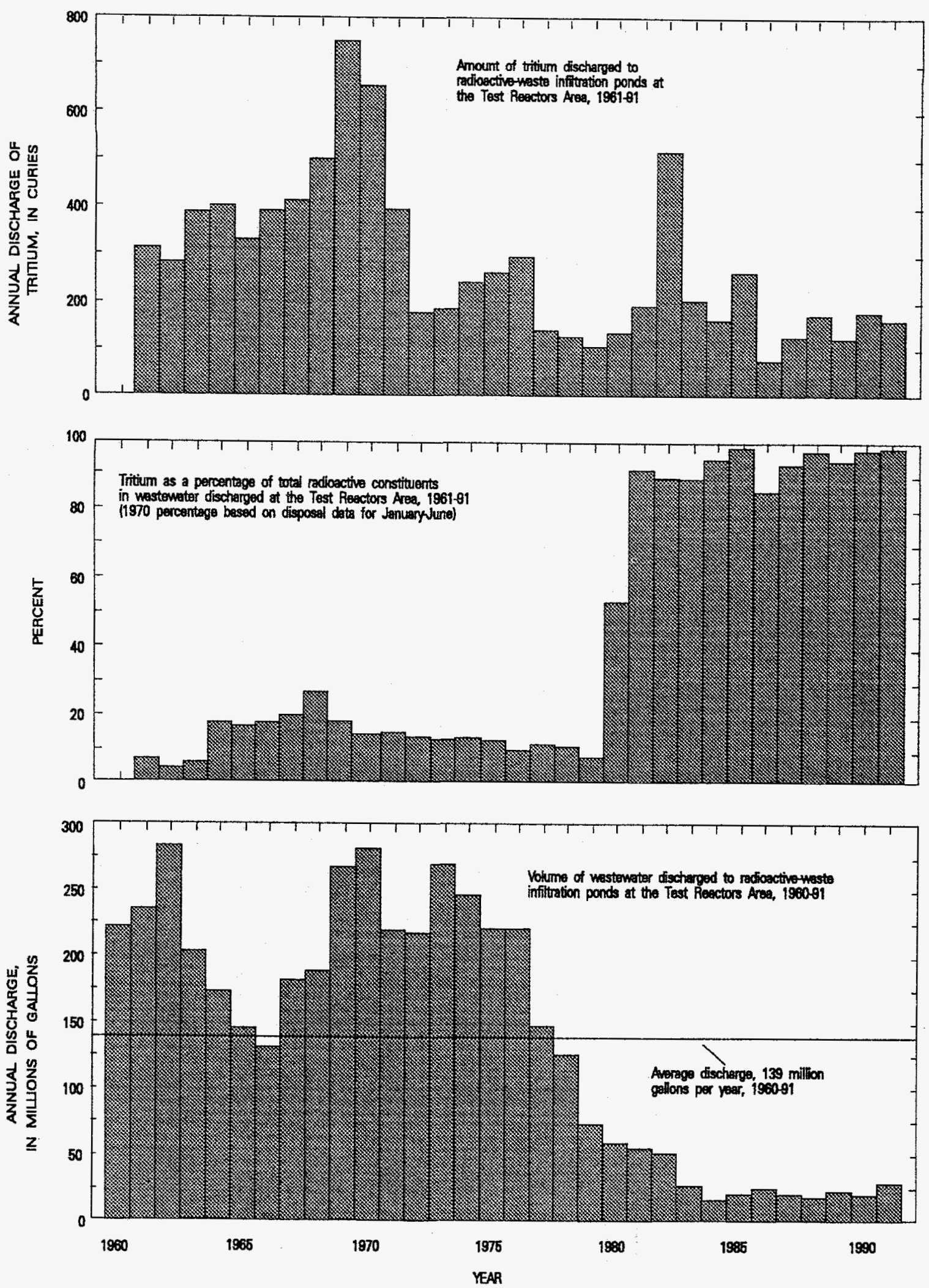

Figure 6. Amount of tritium discharged, tritium as a percentage of total radioactive constituents in wastewater discharged, and volume of wastewater discharged to the radioactive-waste infiltration ponds at the Test Reactors Area, 1960-91. 
for 1989-91 was 23.6 million gal and was much less than the long-term average annual discharge.

In 1976, the DOE contractor at the TRA began a three-phase program to reduce radioactivity in wastewater. The first phase ran from 1976 to 1980 and the second phase ran from 1981 to 1987 . At the end of 1991, the contractor was in the final phase of the program. The decrease in the volume of radioactive wastewater discharged at the TRA may be a result of this program.

In 1989-91, about 97 percent of the radioactivity in wastewater discharged at the TRA was attributed to tritium (fig. 6). In 1974-79, about 10 percent of the radioactivity in wastewater discharged was attributed to tritium; in 1980, about 50 percent was attributed; and in 1981-85, about 90 percent was attributed (Pittman and others, 1988, p. 22).

A chemical-waste infiltration pond has been used for disposal of chemical wastewater from an ion-exchange system at the TRA since 1962 . The average annual discharge to this pond was about 20 million gal for the period 1962-91. Discharge increased from about 4.2 million gal in 1988 to 8.6 million gal in 1991. The average annual discharge for 1989-91 was 7.9 million gal, 40 percent of the long-term average annual discharge of 20 million gal. Sulfate and sodium were the predominant constituents in the chemical wastewater. During 1989-91, average annual amounts of about $493,000 \mathrm{lb}$ of sulfate and $171,000 \mathrm{lb}$ of sodium was discharged to the chemical-waste infiltration pond; average annual concentrations of sulfate and sodium in the wastewater were about 7,500 and $2,600 \mathrm{mg} / \mathrm{L}$, respectively.

A deep disposal well, which currently is used as an observation well, was used from 1964 to March 1982 to inject non-radioactive wastewater from cooling-tower operations at the TRA into the Snake River Plain aquifer. Since March 1982, this wastewater has been discharged to two cold-waste infiltration ponds (fig. 3). The average annual discharge to the well and the infiltration ponds was about 230 million gal during 1964-91 and about 250 million gal during 1989-91. This wastewater contained an average annual amount of about
$428,000 \mathrm{lb}$ of sulfate and $48,000 \mathrm{lb}$ of other chemicals during 1989-91.

About $10 \mathrm{million}$ gal/yr of sewage effluent was discharged to an infiltration pond at the TRA during 1989-91. In 1989 the sewage effluent contained about $1,070 \mathrm{lb}$ of chloride and $1,550 \mathrm{lb}$ of hypochlorite. Chloride and hypochlorite were not part of the sewage effluent after February 1990.

Idaho Chemical Processing Plant.-From 1953 to February 1984, the ICPP discharged most of its low-level radioactive, chemical, and sanitary wastewater into the Snake River Plain aquifer through a $600-\mathrm{ft}$-deep disposal well. The average annual discharge of wastewater to the well was about 363 million gal (Pittman and others, 1988, p. 24). Two infiltration ponds currently are being used for wastewater disposal (fig. 3). The first pond was completed in February 1984 and the second pond was completed in October 1985. The volumes of wastewater discharged to the well and infiltration ponds during 1962-91 are shown in figure 7 . The annual discharge to the well and ponds ranged from 260 million gal in 1963 to 620 million gal in 1990 and averaged about 420 million gal. The average annual discharge during 1989-91 was about 540 million gal.

Most of the radioactivity in wastewater discharged to the infiltration ponds at the ICPP is attributed to tritium. Tritium has accounted for more than 90 percent of the radioactivity in wastewater discharged at the ICPP since 1975 (fig. 7). During 1989-91, tritium accounted for 86 percent of the total radioactivity in wastewater. During 1986-88, $556 \mathrm{Ci}$ of tritium were discharged at the ICPP and the average annual amount was $185 \mathrm{Ci}$ (Orr and Cecil, 1991, p. 20). During 1989-91, only 2.7 $\mathrm{Ci}$ of tritium were discharged.

During 1989-91, chloride, fluoride, nitrate, and sulfate were the predominant chemical constituents in wastewater discharged to the ICPP infiltration ponds. Average annual amounts of about $1,202,000 \mathrm{lb}$ of chloride; $1,850 \mathrm{lb}$ of fluoride; $56,100 \mathrm{lb}$ of nitrate; and $192,000 \mathrm{lb}$ of sulfate were in wastewater discharged at the ICPP.

Naval Reactors Facility.-Wastewater at the Naval Reactors Facility (NRF) (fig. 1) is 

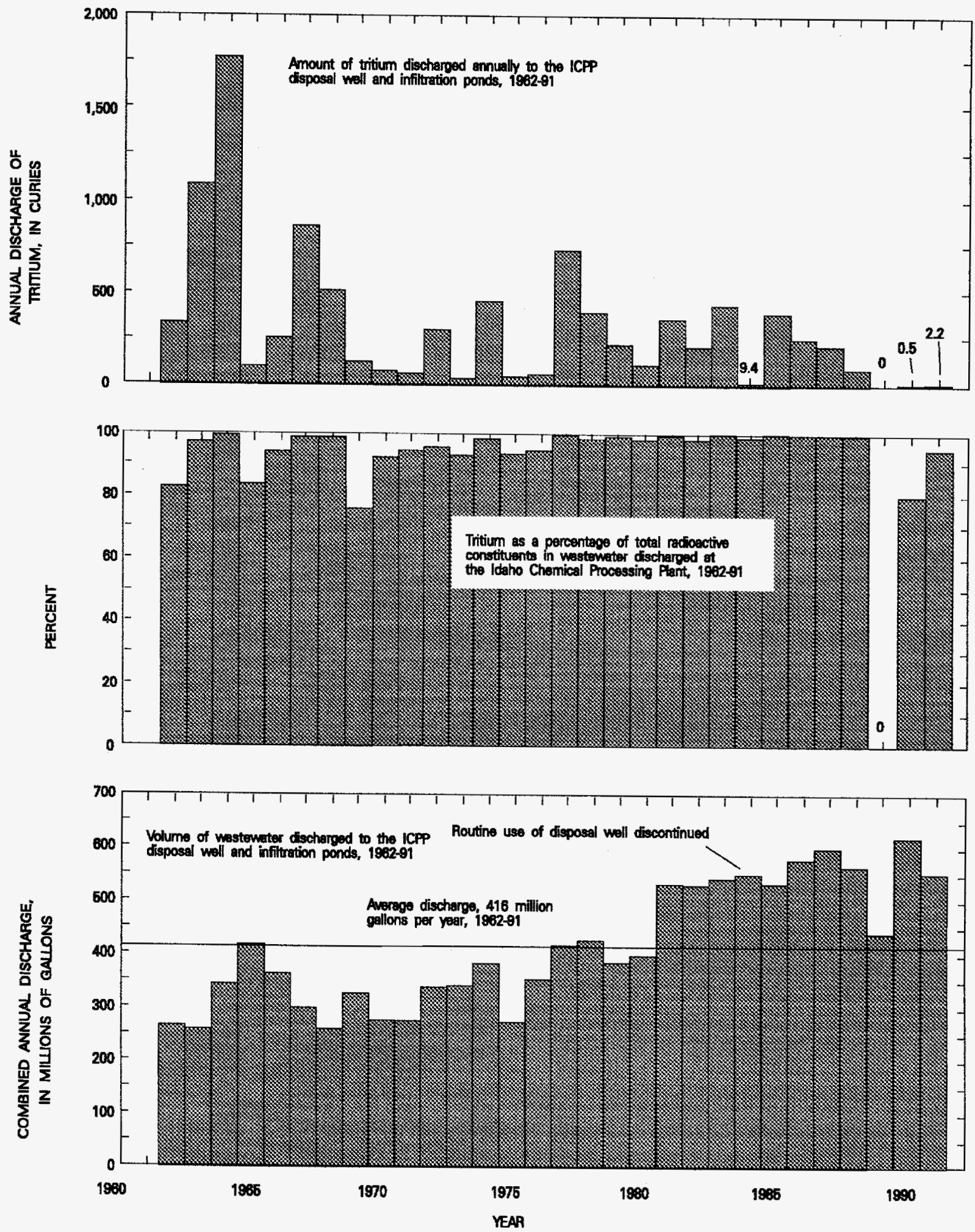

Figure 7. Amount of tritium discharged, tritium as a percentage of total radioactive constituents in wastewater discharged, and volume of wastewater discharged to the disposal well and infiltration ponds at the Idaho Chemical Processing Plant, 1962-91. 
discharged to a 3-mi-long industrial-waste ditch and to sewage ponds. During 1989-91, about $94 \mathrm{million} \mathrm{gal} / \mathrm{yr}$ of wastewater was discharged to the industrial-waste ditch. About $21 \mathrm{million}$ gal/yr of sewage effluent was discharged to the sewage ponds. The 1989-91 disposal rates represent an increase since $1986-88$, when $36 \mathrm{million}$ gal/yr was discharged (Orr and Cecil, 1991, p. 20).

Chloride, sulfate, and sodium were the predominant chemical constituents in wastewater discharged to the industrial-waste ditch. About $145,000 \mathrm{lb}$ of chloride, $175,000 \mathrm{lb}$ of sulfate, and $87,500 \mathrm{lb}$ of sodium was discharged annually during 1989-91. These amounts reflect disposalrate increases from the average annual amounts discharged during 1986-88 (Orr and Cecil, 1991). The average annual amount of all other chemical constituents in the wastewater was about $15,000 \mathrm{lb}$.

Radioactive Waste Management Complex.Solid and liquid radioactive and chemical wastes have been buried in trenches and pits at the Subsurface Disposal Area (SDA) at the RWMC (fig. 3) since 1952. Before 1970, little or no sediment was retained between the excavation bottoms and the underlying basalt. Since 1970, a layer of sediment has been retained in excavations to inhibit downward migration of waste constituents. These constituents include transuranic wastes (buried in trenches until 1970), other radiochemical and inorganic chemical constituents, and organic compounds.

About $550 \mathrm{Ci}$ of plutonium-238; $21,000 \mathrm{Ci}$ of plutonium-239; 4,900 Ci of plutonium-240; $165,000 \mathrm{Ci}$ of plutonium-241; and $51,000 \mathrm{Ci}$ of Americium-241 were buried in the SDA during 1954-70 (Barraclough and others, 1976, p. 11). An estimated $88,400 \mathrm{gal}$ of organic waste was buried before 1970 (Mann and Knobel, 1987, p. 1). These buried wastes included about 24,400 gal of carbon tetrachloride; 39,000 gal of lubricating oil; and about 25,000 gal of other organic compounds, including trichloroethane, trichloroethylene, perchloroethylene, toluene, and benzene.

Test Area North--From 1953 to 1972, lowlevel radioactive, chemical, and sanitary waste- water was discharged at TAN (fig. 1) into the Snake River Plain aquifer through a 310-ft-deep disposal well (TAN Disp., fig. 2). In 1972, the disposal well was replaced by a 35 -acre infiltration pond. No records are available as to the amount of radioactivity in wastewater discharged at TAN prior to 1959. During 1959-91, about $61 \mathrm{Ci}$ of radioactivity was discharged in wastewater to the disposal well and infiltration pond. Of this amount, about $20 \mathrm{Ci}$ was discharged to the disposal well in 1968 and 1969 in response to problems with an evaporator used to reduce the volume of liquid waste (Energy Research and Development Administration, 1977, p. II-110, II-111).

During 1989-91, an average of about 18.4 million gal/yr volume of radioactive wastewater was discharged to the infiltration pond at TAN. The average rate of disposal of radioactivity in this wastewater was $0.061 \mathrm{Ci} / \mathrm{yr}$.

An average of about $27.9 \mathrm{million} \mathrm{gal} / \mathrm{yr}$ of chemical wastewater was discharged to the infiltration pond during 1989-91. The predominant constituents were chloride and sodium. Average annual amounts of $11,500 \mathrm{lb}$ of chloride and 7,500 $\mathrm{lb}$ of sodium were discharged. The average annual amount of all other chemical constituents in the wastewater was about $6,000 \mathrm{lb}$.

Central Facilities Area.-An average annual volume of about 40 million gal of wastewater was discharged to the sewage-plant tile drain field at the CFA (fig. 1) during 1989-91. Most radioactive wastes discharged to this drain field are from pumpage of production well CFA-1 (fig. 4), which obtains water from within the ICPP contaminant plume in the Snake River Plain aquifer. Most of the radioactivity in wastewater discharged at the CFA is attributed to tritium. During 1989-91, tritium accounted for 99.7 percent of the total radioactivity in wastewater discharged at the CFA and averaged about $1.9 \mathrm{Ci} / \mathrm{yr}$.

Chloride and sodium are the predominant constituents in chemical and laundry wastewater discharged to the drain field at the CFA. During 1989-91, average annual amounts of about $400,000 \mathrm{lb}$ of chloride and $410,000 \mathrm{lb}$ of sodium were contained in wastewater discharged to the 
drain field. The average annual amount of all other chemical constituents in the wastewater was about $247,000 \mathrm{lb}$.

\section{HYDROLOGIC CONDITIONS}

The Snake River Plain aquifer is one of the most productive aquifers in the United States (U.S. Geological Survey, 1985, p. 193). The aquifer consists of a thick sequence of basalts and sedimentary interbeds filling a large, arcuate, structural basin in southeastern Idaho (fig. 1).

Recharge to the Snake River Plain aquifer is principally from infiltration of applied irrigation water, infiltration of streamflow, and ground-water inflow from adjoining mountain drainage basins. Some recharge may be from direct infiltration of precipitation, although the small amount of annual precipitation on the plain ( 8 in. at the INEL), evapotranspiration, and the great depth to water (in places exceeding $900 \mathrm{ft}$ ) probably minimize this source of recharge.

\section{Surface Water}

The Big Lost River drains more than $1,400 \mathrm{mi}^{2}$ of mountainous area that includes parts of the Lost River Range and Pioneer Range west of the INEL (fig. 1). Flow in the Big Lost River infiltrates to the Snake River Plain aquifer along its channel and at sinks and playas at the river's terminus. To avoid flooding at the INEL facilities, excess runoff has been diverted since 1958, to spreading areas in the southwestern part of the INEL, where much of the water rapidly infiltrates to the aquifer. Other surface drainages that provide recharge to the Snake River Plain aquifer at the INEL include Birch Creek, Little Lost River, and Camas Creek (fig. 1).

The average streamflow in the Big Lost River below Mackay Reservoir (fig. 1) for the 75-yr period of record (water years 1905, 1913-14, and 1920-91) was 223,900 acre-ft/yr (Harenberg and others, 1992, p. 179). Streamflow in the Big Lost River below Mackay Reservoir (fig. 8) increased from 135,200 acre-ft ( 60 percent of average flow) during the 1989 water year (Harenberg and others,
1990) to 165,100 acre- $\mathrm{ft}$ (74 percent of average flow) during the 1991 water year (Harenberg and others, 1992). No streamflow was recorded for the Big Lost River near Arco (fig. 1), the Big Lost River below the INEL diversion near Arco (fig. 1), or the INEL diversion at its head near Arco (fig. 8) during the 1989-91 water years.

Before 1989, recharge to the Snake River Plain aquifer downstream from Arco was substantial because of infiltration of streamflow from the Big Lost River channel, diversion areas, sinks, and playas. For example, measured infiltration losses at various discharges ranged from 1 to $28\left(\mathrm{ft}^{3} / \mathrm{s}\right) / \mathrm{mi}$ (Bennett, 1990, p. 1).

\section{Ground Water}

Water in the Snake River Plain aquifer moves principally through fractures and interflow zones in the basalt. A significant proportion of the ground water moves through the upper $800 \mathrm{ft}$ of saturated rocks. Estimates of hydraulic conductivity of basalt in the upper part of the aquifer range from .0086 to $5,500 \mathrm{ft} /$ day (Ackerman, 1991, p. 30). Hydraulic conductivity of underlying rocks is probably several orders of magnitude smaller. The effective base of the Snake River Plain aquifer at the INEL probably ranges from about 850 to $1,220 \mathrm{ft}$ below land surface (Mann, 1986, p. 21).

Depth to water in wells completed in the Snake River Plain aquifer ranges from about $200 \mathrm{ft}$ in the northern part of the INEL to more than $900 \mathrm{ft}$ in the southeastern part. In July 1991, the altitude of the water table was about $4,585 \mathrm{ft}$ above sea level in the northern part of the INEL (fig. 9) and about $4,425 \mathrm{ft}$ above sea level in the southwestern part. Water flowed southward and southwestward beneath the INEL (fig. 9) at an average hydraulic gradient of about $4 \mathrm{ft} / \mathrm{mi}$. Locally, however, the hydraulic gradient ranged from about 1 to $15 \mathrm{ft} / \mathrm{mi}$. From April-August 1988 to April-August 1991, water levels generally declined throughout the INEL because of drought conditions that began in 1987. Water-level declines ranged from $10 \mathrm{ft}$ in a well in the central part of the INEL to $2 \mathrm{ft}$ in wells in the southeastern part (fig. 10). The larger waterlevel decline in wells in the central part of the 


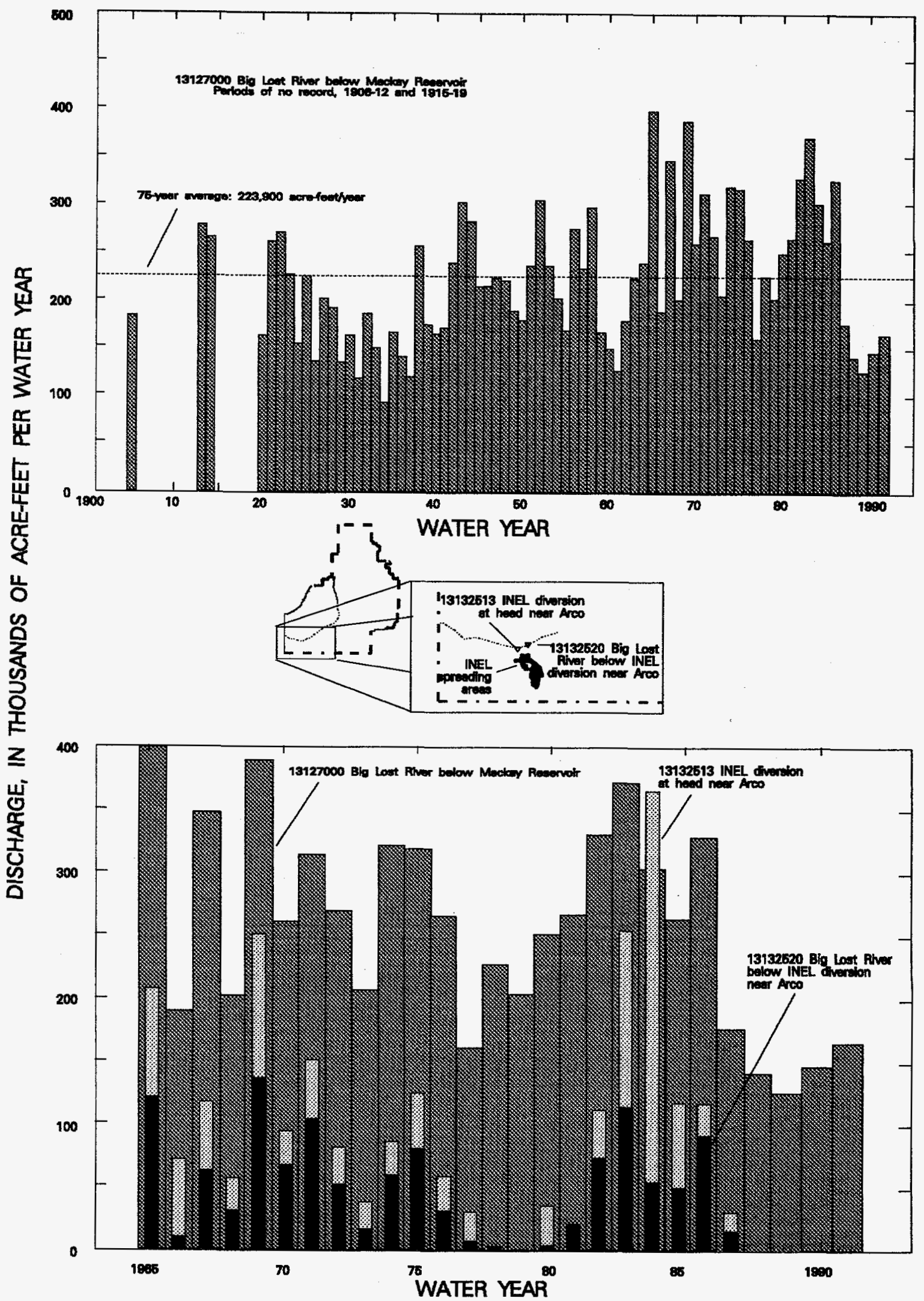

Figure 8. Discharge of the Big Lost River below Mackay Reservoir (water years 1905, 1913-14, and 1920-91), Big Lost River below the INEL diversion near Arco, and the INEL diversion at head near Arco (water years 1965-91). 
EXPLANATION

WATER-TABLE Contour - Shows altitude of water table. Interval 10 feet. Datum is sea level

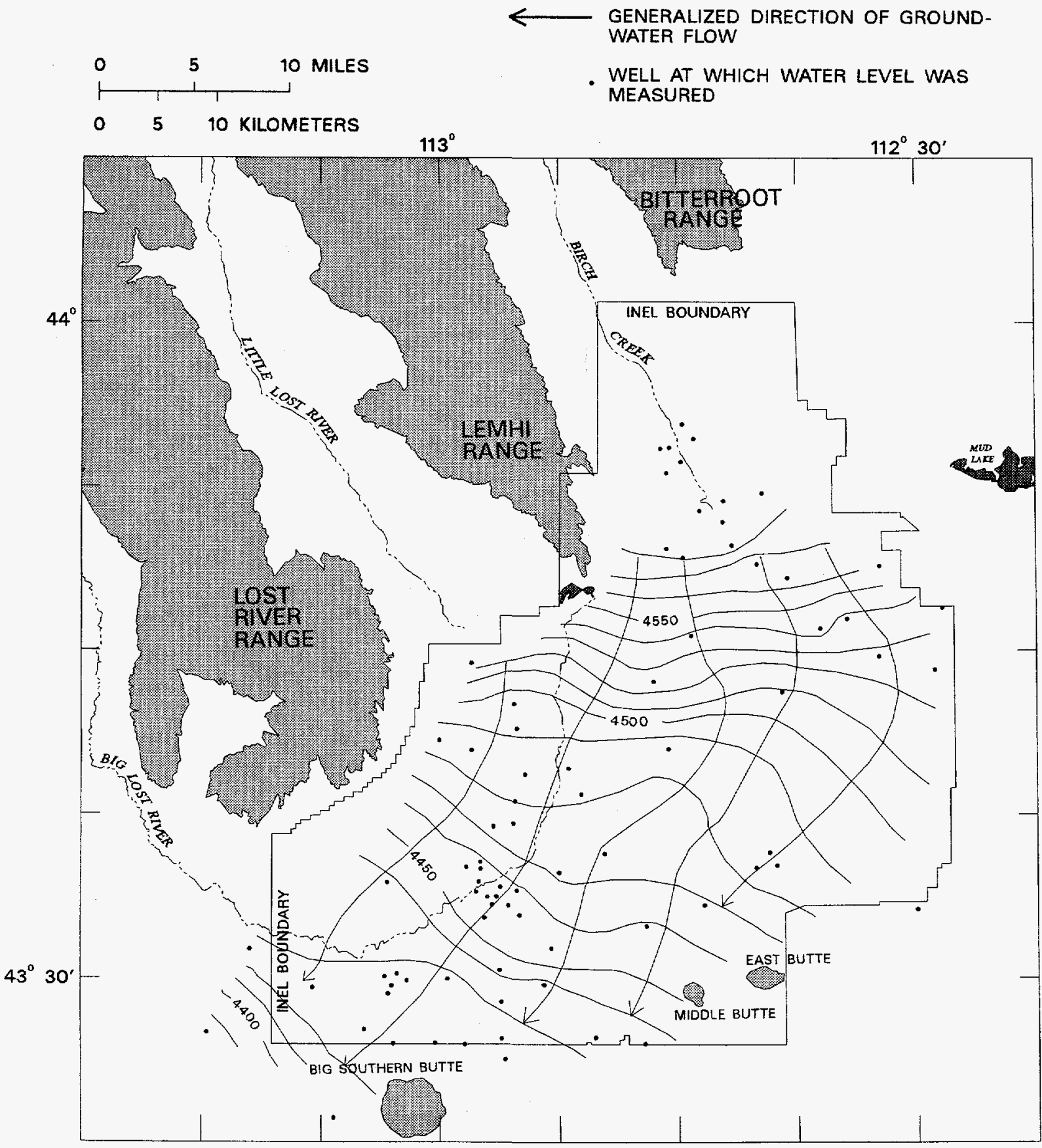

Figure 9. Altitude of the water table and generalized direction of ground-water flow in the Snake River Plain aquifer in the vicinity of the Idaho National Engineering Laboratory, July 1991. 
EXPLANATION

LINE OF EQUAL WATER-LEVEL DECLINE interval variable, in feet

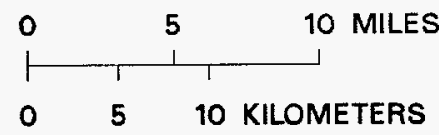

- WeLL AT WHICH WATER LEVEL WAS MEASURED

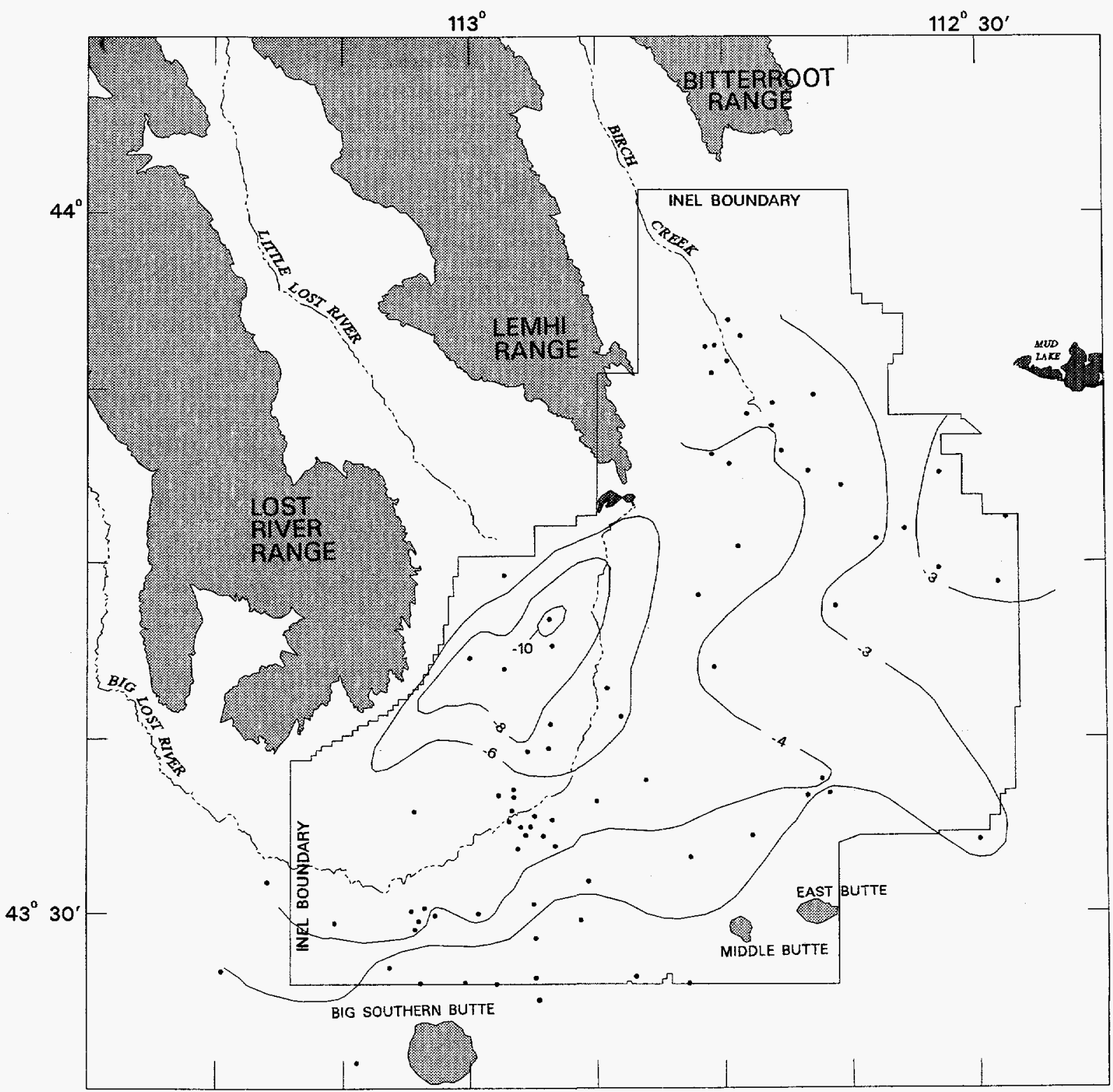

Figure 10. Generalized decline in ground-water levels in the Snake River Plain aquifer in the vicinity of the Idaho National Engineering Laboratory, April-August 1988 to April-August 1991. 
INEL is attributed to lack of recharge from the Big Lost River.

Water levels monitored in wells $12,17,23$ (fig. 2), and 20 (fig. 3) show water-level changes in the Snake River Plain aquifer at different locations at the INEL. Water levels in these wells fluctuated in response to streamflow during 1950-91 (fig. 11). Long-term water-level fluctuations ranged from about $10 \mathrm{ft}$ in well 20 to about $22 \mathrm{ft}$ in well 12. Water levels in these wells declined during 1989-91 because there was no streamflow in the Big Lost River below Arco and because of a general decline in recharge to the aquifer.

Ground water moves southwestward from the INEL and eventually is discharged to springs along the Snake River downstream from Twin Falls, $100 \mathrm{mi}$ southwest of the INEL. About 4.3 million acre-ft of ground water was discharged to these springs in 1988 (Mann, 1989, p. 2).

\section{SELECTED RADIOCHEMICAL AND CHEMICAL CONSTITUENTS IN AND PHYSICAL PROPERTIES OF WATER IN THE SNAKE RIVER PLAIN AQUIFER}

Contaminant plumes of radiochemical and chemical constituents in the Snake River Plain aquifer at the INEL are attributed to waste-disposal practices. The areal distribution of the plumes are approximately defined from concentrations of these constituents in water samples from wells completed in the aquifer. No attempt is made to determine the vertical extent and distribution of these plumes. Radiochemical and chemical constituents detected in ground water at the INEL include tritium, strontium-90, cobalt- 60 , cesium-137, plutonium-238, plutonium-239,-240 (undivided), americium-241, dissolved and hexavalent chromium, sodium, chloride, sulfate, nitrate, lead, mercury, and purgeable organic compounds.

\section{Tritium}

A tritium plume has developed in the Snake River Plain aquifer from disposal of wastewater at the INEL since the 1950 's. The principal sources of tritium in the aquifer have been the injection of wastewater through the disposal well at the ICPP and the discharge of wastewater to the infiltration ponds at the ICPP and TRA. About $31,300 \mathrm{Ci}$ of tritium was discharged to the well and ponds since 1952. Routine use of the disposal well ended in February 1984; subsequently, most radioactive wastewater has been discharged to the infiltration ponds. During 1989-91, only about $2.7 \mathrm{Ci}$ of tritium were discharged to the ponds at the ICPP and about $470 \mathrm{Ci}$ was discharged to the ponds at the TRA. Tritium has a half-life of 12.3 years (Walker and others, 1989, p. 20).

In October 1991, wells with tritium concentrations greater than the reporting level ranged from $0.6 \pm 0.2$ to $41.7 \pm 0.9 \mathrm{pCi} / \mathrm{mL}$ and the tritium plume extended southwestward in the general direction of ground-water flow (fig. 12). The area of the plume in which tritium concentrations exceeded 0.5 $\mathrm{pCi} / \mathrm{mL}$ decreased from about $51 \mathrm{mi}^{2}$ in October 1985 to about $45 \mathrm{mi}^{2}$ in October 1988 (Orr and Cecil, 1991) and to about $40 \mathrm{mi}^{2}$ in October 1991. The area of the plume in which tritium concentrations exceeded the maximum contaminant level (MCL) of $20 \mathrm{pCi} / \mathrm{mL}$ (U.S. Environmental Protection Agency, 1989, p. 551) decreased from $2.8 \mathrm{mi}^{2}$ in 1988 to $2.4 \mathrm{mi}^{2}$ in 1991 .

Tritium concentrations in water from wells in the Snake River Plain aquifer decreased by as much as $23.8 \mathrm{pCi} / \mathrm{mL}$ during 1989-91. Tritium concentrations in water from well 65 (fig. 5), near the TRA, decreased from $61.6 \pm 1.1 \mathrm{pCi} / \mathrm{mL}$ in 1988 to $37.8 \pm 0.8 \mathrm{pCi} / \mathrm{mL}$ in 1991 . Tritium concentrations in water from well 77 , south of the ICPP, decreased from $50.5 \pm 0.9 \mathrm{pCi} / \mathrm{mL}$ in 1988 to $41.7 \pm 0.9 \mathrm{pCi} / \mathrm{mL}$ in 1991 (table 2). Tritium concentrations in water from wells 103,105 , and 108 , near the southern boundary of the INEL (fig. 4), exceeded the reporting level during 1983-85 (Pittman and others, 1988, p. 51; Mann and Cecil, 1990 , p. 27). Since 1985 , tritium concentrations in water from these wells have been less than the reporting level.

Tritium concentrations in water from wells 83 and EBR-1 (fig. 4) within the tritium plume (fig 12) are below the reporting level. Well 83 
DEPTH TO WATER, IN FEET BELOW LAND SURFACE

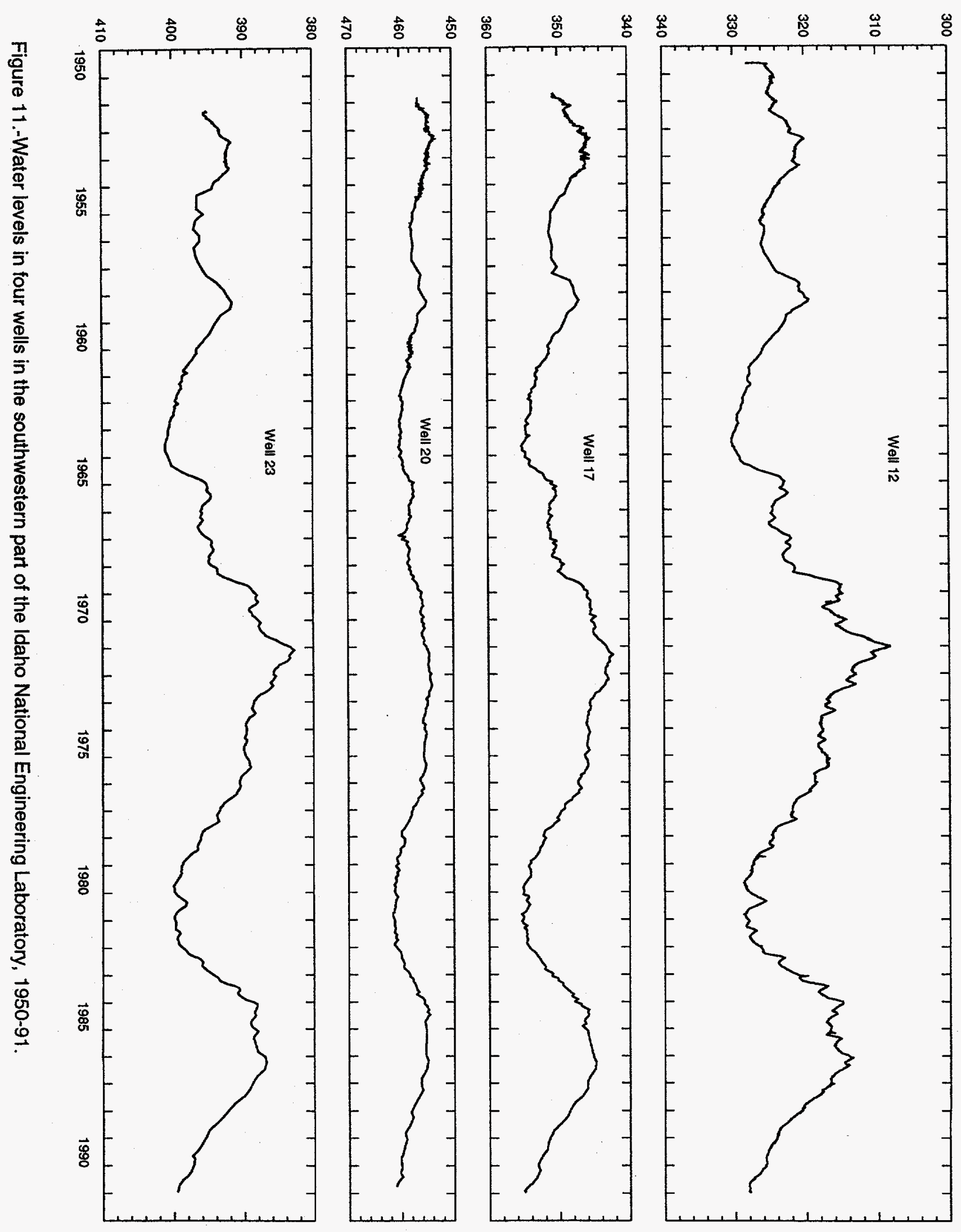




\section{EXPLANATION}

LINE OF EQUAL TRITIUM CONCENTRATION Interval variable; concentration in picocuries per milliliter

- WELL COMPLETED IN THE SNAKE RIVER PLAIN AQUIFER AND SAMPLED FOR TRITIUM

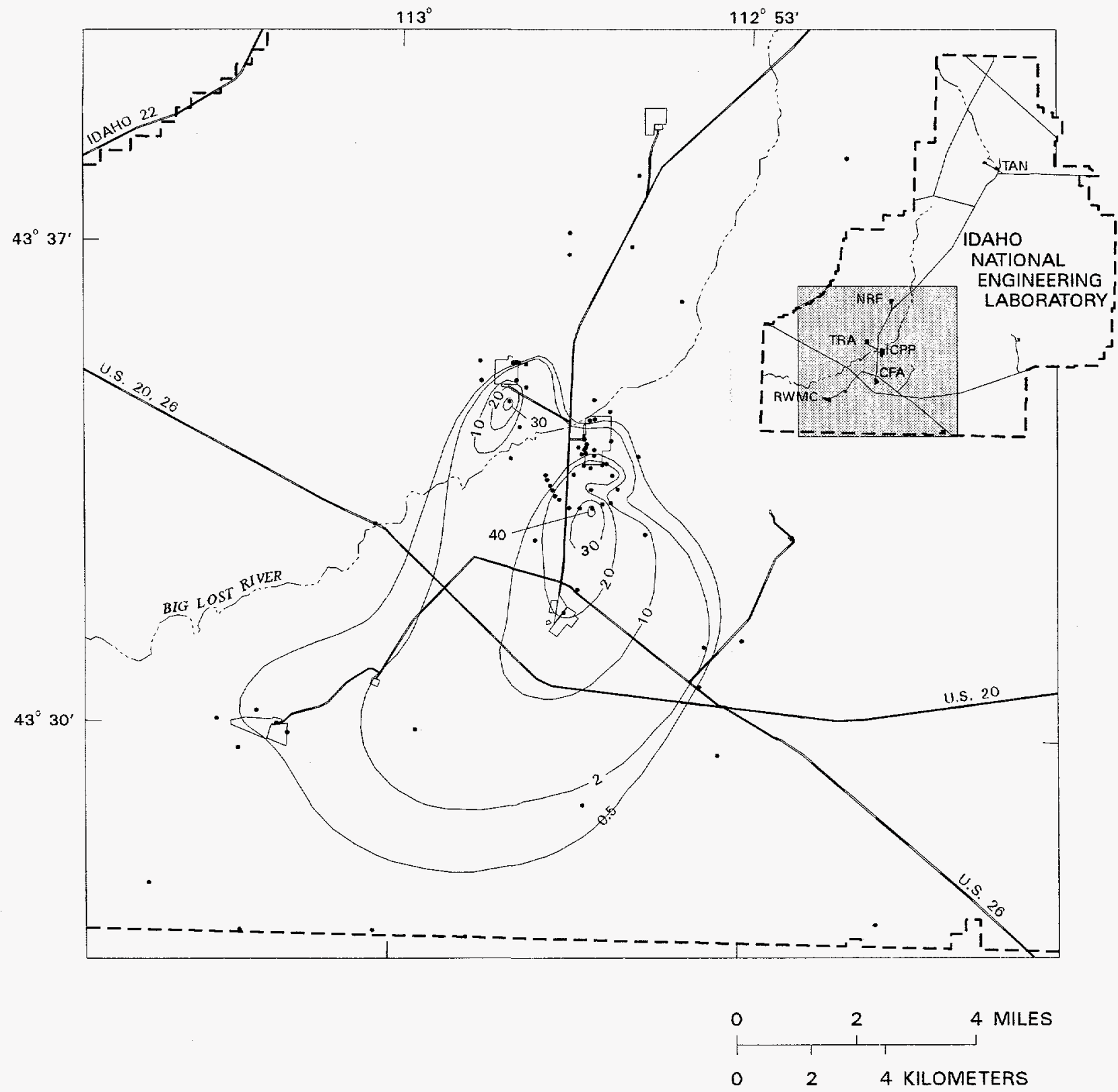

Figure 12. Distribution of tritium in water from the Snake River Plain aquifer at the Idaho National Engineering Laboratory, October 1991. 
Table 2. Tritium concentrations in water from selected wells at the Idaho National Engineering Laboratory, 1980-91

[Concentrations and associated uncertainties in picocuries per milliliter. Analytical uncertainties are reported as $1 \mathrm{s.}$ Location of wells shown on figures 4 and 5 ; --, no data, well drilled in 1984]

\begin{tabular}{|c|c|c|c|c|c|}
\hline \multicolumn{2}{|c|}{ Well 47} & \multicolumn{2}{|c|}{ Well 111} & \multicolumn{2}{|c|}{ Well 38} \\
\hline Date & Concentration & Date & Concentration & Date & Concentration \\
\hline $10 / 13 / 80$ & $27.9 \pm 0.6$ & & -- & $10 / 17 / 80$ & $87.8 \pm 1.1$ \\
\hline $10 / 29 / 81$ & $27.9 \pm 0.6$ & & -- & $10 / 08 / 81$ & $77.5 \pm 0.8$ \\
\hline $10 / 07 / 82$ & $15.3 \pm 4.0$ & & -- & $10 / 07 / 82$ & $74.1 \pm 0.8$ \\
\hline $10 / 17 / 83$ & $73.0 \pm 0.9$ & & -- & $10 / 13 / 83$ & $70.9 \pm 0.9$ \\
\hline $10 / 23 / 84$ & $14.0 \pm 0.5$ & & -- & $10 / 09 / 84$ & $66.7 \pm 0.9$ \\
\hline $10 / 29 / 85$ & $12.0 \pm 0.5$ & $11 / 05 / 85$ & $29.5 \pm 0.8$ & $10 / 28 / 85$ & $55.8 \pm 1.2$ \\
\hline $10 / 29 / 86$ & $5.8 \pm 0.4$ & $10 / 27 / 86$ & $49.2 \pm 1.1$ & $11 / 18 / 86$ & $59.5 \pm 0.9$ \\
\hline $10 / 26 / 87$ & $3.5 \pm 0.4$ & $9 / 25 / 87$ & $57.5 \pm 1.2$ & $10 / 16 / 87$ & $65.9 \pm 1.3$ \\
\hline $9 / 30 / 88$ & $3.5 \pm 0.2$ & $10 / 04 / 88$ & $37.6 \pm 0.8$ & $11 / 07 / 88$ & $45.0 \pm 5.0$ \\
\hline $10 / 19 / 89$ & $5.0 \pm 0.3$ & $10 / 04 / 89$ & $29.4 \pm 0.7$ & $10 / 31 / 89$ & $40.2 \pm 0.8$ \\
\hline $10 / 31 / 90$ & $7.5 \pm 0.4$ & $9 / 24 / 90$ & $32.9 \pm 0.7$ & $10 / 05 / 90$ & $31.9 \pm 0.7$ \\
\hline $10 / 24 / 91$ & $6.2 \pm 0.3$ & $10 / 25 / 91$ & $18.3 \pm 0.5$ & $10 / 03 / 91$ & $26.3 \pm 0.7$ \\
\hline \multicolumn{2}{|c|}{ Well 77} & \multicolumn{2}{|c|}{ Well CFA-1 } & \multicolumn{2}{|c|}{ Well 59} \\
\hline Date & Concentration & Date & Concentration & Date & Concentration \\
\hline $10 / 13 / 80$ & $93.0 \pm 1.0$ & $10 / 21 / 80$ & $41.0 \pm 0.6$ & $10 / 24 / 80$ & $31.5 \pm 0.6$ \\
\hline $10 / 05 / 81$ & $79.9 \pm 0.8$ & $10 / 13 / 81$ & $35.6 \pm 0.6$ & $10 / 06 / 81$ & $29.7 \pm 0.6$ \\
\hline $9 / 30 / 82$ & $81.5 \pm 0.8$ & $10 / 11 / 82$ & $33.1 \pm 0.6$ & $10 / 06 / 82$ & $25.2 \pm 0.4$ \\
\hline $10 / 04 / 83$ & $63.5 \pm 0.9$ & $10 / 06 / 83$ & $31.5 \pm 0.6$ & $10 / 13 / 83$ & $59.7 \pm 0.9$ \\
\hline $10 / 09 / 84$ & $70.5 \pm 0.9$ & $10 / 12 / 84$ & $33.8 \pm 0.7$ & $10 / 10 / 84$ & $14.1 \pm 0.5$ \\
\hline $10 / 22 / 85$ & $46.3 \pm 1.0$ & $10 / 25 / 85$ & $32.4 \pm 0.8$ & $10 / 30 / 85$ & $42.0 \pm 1.3$ \\
\hline $11 / 13 / 86$ & $70.0 \pm 0.9$ & $10 / 31 / 86$ & $34.8 \pm 0.9$ & $11 / 14 / 86$ & $16.7 \pm 0.7$ \\
\hline $10 / 20 / 87$ & $60.2 \pm 1.2$ & $10 / 15 / 87$ & $32.1 \pm 0.8$ & $10 / 06 / 87$ & $3.6 \pm 0.4$ \\
\hline $11 / 06 / 88$ & $50.5 \pm 0.9$ & $10 / 28 / 88$ & $27.3 \pm 0.6$ & $10 / 21 / 88$ & $3.3 \pm 0.3$ \\
\hline $10 / 30 / 89$ & $41.2 \pm 0.8$ & $10 / 26 / 89$ & $22.0 \pm 0.6$ & $10 / 23 / 89$ & $2.4 \pm 0.2$ \\
\hline $10 / 25 / 90$ & $40.7 \pm 0.8$ & $10 / 15 / 90$ & $17.2 \pm 0.5$ & $10 / 12 / 90$ & $6.7 \pm 0.3$ \\
\hline $10 / 09 / 91$ & $41.7 \pm 0.9$ & $10 / 10 / 91$ & $21.1 \pm 0.6$ & $10 / 21 / 91$ & $19.3 \pm 0.6$ \\
\hline
\end{tabular}


penetrates about 250 ft of the Snake River Plain aquifer and EBR-1 penetrates about $490 \mathrm{ft}$ of the aquifer. Most of the other wells in the tritium plume penetrate only the uppermost $5010200 \mathrm{ft}$ of the aquifer. Tritium concentrations in water from wells 83 and EBR-1 are below the reporting level probably because of dilution by water from deeper zones (Mann and Cecil, 1990, p. 18).

Tritium concentrations in water from wells south of the ICPP generally decreased during 1980-91 (table 2) in response to a decreased rate of tritium disposal from the ICPP. Tritium concentrations in water from well 59 near the ICPP infiltration ponds generally have decreased since 1980 , but unusually large concentrations were measured in October 1983, 1985, and 1991 (table 2). In 1986, the well was modified because perched water was detected outside the casing. Perched water seeping into the well may have been the reason for the larger concentrations in 1983 and 1985. The larger concentration in 1991 also may be attributed to seepage from a perched zone. A video log of well 59 after modifications in 1986 showed that some water from the perched zone was still seeping into the well. The increased concentrations in 1991 correlated with the use of the west infiltration pond (fig. 3).

Long-term radioactive-decay processes and an overall decrease in tritium disposal rates has contributed to decreased concentrations of tritium and the decreased area of the tritium plume at the INEL in 1989-91. Of the total of $31,300 \mathrm{Ci}$ of tritium discharged to the aquifer from 1952 to 1991 , only about 9,000 Ci remained after radioactive decay. The average combined rate of tritium disposal at the TRA and ICPP during 1962-91 was $590 \mathrm{Ci} / \mathrm{yr}$. The average combined rate was $363 \mathrm{Ci} / \mathrm{yr}(62$ percent of the long-term average) during 1979-91 and $279 \mathrm{Ci} / \mathrm{yr}$ (47 percent of the long-term average) during 1984-91. Also, the distribution of tritium concentrations in ground water probably has been affected by the shutdown of the ICPP disposal well in 1984 and the subsequent discharge of wastewater to infiltration ponds.

\section{Strontium-90}

A strontium-90 plume has developed in the Snake River Plain aquifer from disposal of wastewater at the INEL. During 1962-63, more than 33. $\mathrm{Ci}$ of strontium-90 in wastewater was discharged into a pit at the ICPP (Robertson and others, 1974, p. 127). In addition, during 1961-91 about $17.5 \mathrm{Ci}$ of strontium-90 was in wastewater injected directly into the aquifer through the ICPP disposal well and discharged to infiltration ponds at the ICPP. About $78 \mathrm{Ci}$ of strontium-90 was disposed to radioactive-waste infiltration ponds at the TRA during 1952-91. During 1989-91, about $0.08 \mathrm{Ci}$ of strontium- 90 was discharged to infiltration ponds at the INEL with most of it discharged to the ICPP infiltration ponds. Strontium-90 has a half-life of 29.1 years (Walker and others, 1989 , p. 29).

In October 1991, the 16 wells with concentrations of strontium- 90 greater than the reporting level ranged from $9 \pm 3$ to $55 \pm 4 \mathrm{pCi} / \mathrm{L}$ and the plume extended southwestward in the general direction of ground-water flow (fig. 13). Concentrations of strontium-90 in water samples from most wells have remained relatively constant since 1988. An exception is the concentration in well 37 . which was above the reporting level through 1990 but was below the reporting level in 1991 (table 3). The MCL for strontium-90 in drinking water is $8 \mathrm{pCi} / \mathrm{L}$ (U.S. Environmental Protection Agency, 1989, p. 551).

During 1989-91, strontium-90 concentrations in water from wells around the ICPP remained relatively constant. Before 1989 , strontium-90 concentrations had been decreasing because of changes in disposal practices and processes of radioactive decay, diffusion, dispersion, and dilution from natural recharge (Orr and Cecil, 1991, p. 35 ). The relatively constant strontium-90 concentrations in water from wells sampled during 1989-91 may be due, in part, to a lack of recharge from the Big Lost River. Also, an increase in disposal of other constituents into the infiltration ponds may have affected the exchange capacity of strontium-90 in the unsaturated zone. The absence of a strontium-90 plume at the TRA probably can 
Table 3. Strontium- 90 concentrations in water from selected wells at the Idaho National Engineering Laboratory, 1981-91

[Concentrations and associated uncertainties in picocuries per liter. Analytical uncertainties are reported as 1s. Location of wells shown on figure 5]

\begin{tabular}{|c|c|c|c|c|c|}
\hline \multicolumn{2}{|c|}{ Well 47} & \multicolumn{2}{|c|}{ Well 57} & \multicolumn{2}{|c|}{ Well 38} \\
\hline Date & Concentration & Date & Concentration & Date & Concentration \\
\hline $10 / 08 / 81$ & $79 \pm 5$ & $10 / 05 / 81$ & $93 \pm 6$ & $10 / 08 / 81$ & $28 \pm 3$ \\
\hline $10 / 07 / 82$ & $60 \pm 4$ & $10 / 06 / 82$ & $90 \pm 5$ & $10 / 07 / 82$ & $27 \pm 3$ \\
\hline $10 / 17 / 83$ & $130 \pm 7$ & $10 / 13 / 83$ & $83 \pm 5$ & $10 / 13 / 83$ & $12 \pm 2$ \\
\hline $10 / 23 / 84$ & $61 \pm 4$ & $10 / 10 / 84$ & $66 \pm 6$ & $10 / 09 / 84$ & $26 \pm 4$ \\
\hline $10 / 29 / 85$ & $63 \pm 5$ & $10 / 29 / 85$ & $74 \pm 5$ & $10 / 28 / 85$ & $14 \pm 2$ \\
\hline $10 / 29 / 86$ & $56 \pm 4$ & $11 / 14 / 86$ & $42 \pm 3$ & $11 / 18 / 86$ & $13 \pm 2$ \\
\hline $10 / 26 / 87$ & $54 \pm 3$ & $10 / 09 / 87$ & $49 \pm 3$ & $10 / 16 / 87$ & $13 \pm 2$ \\
\hline $9 / 30 / 88$ & $48 \pm 3$ & $10 / 05 / 88$ & $41 \pm 3$ & $11 / 07 / 88$ & $32 \pm 3$ \\
\hline $10 / 19 / 89$ & $59 \pm 4$ & $12 / 22 / 89$ & $45 \pm 4$ & $10 / 31 / 89$ & $9 \pm 2$ \\
\hline $10 / 31 / 90$ & $51 \pm 4$ & $10 / 29 / 90$ & $41 \pm 4$ & $10 / 05 / 90$ & $22 \pm 3$ \\
\hline $10 / 24 / 91$ & $55 \pm 4$ & $10 / 24 / 91$ & $40 \pm 4$ & $10 / 03 / 91$ & $9 \pm 3$ \\
\hline \multicolumn{2}{|c|}{ Well 37} & \multicolumn{2}{|c|}{ Well 67} & \multicolumn{2}{|c|}{ Well 36} \\
\hline Date & Concentration & Date & Concentration & Date & Concentration \\
\hline $10 / 07 / 81$ & $25 \pm 3$ & $10 / 06 / 81$ & $54 \pm 3$ & $10 / 08 / 81$ & $24 \pm 2$ \\
\hline $10 / 07 / 82$ & $30 \pm 3$ & $10 / 07 / 82$ & $63 \pm 4$ & $10 / 07 / 82$ & $10 \pm 2$ \\
\hline $10 / 10 / 83$ & $26 \pm 3$ & $10 / 05 / 83$ & $67 \pm 4$ & $10 / 13 / 83$ & $15 \pm 2$ \\
\hline $10 / 10 / 84$ & $17 \pm 2$ & $10 / 17 / 84$ & $39 \pm 3$ & $10 / 09 / 84$ & $32 \pm 4$ \\
\hline $10 / 28 / 85$ & $18 \pm 3$ & $10 / 28 / 85$ & $28 \pm 3$ & $10 / 28 / 85$ & $40 \pm 4$ \\
\hline $10 / 27 / 86$ & $21 \pm 2$ & $10 / 29 / 86$ & $23 \pm 2$ & $11 / 18 / 86$ & $10 \pm 2$ \\
\hline $10 / 05 / 87$ & $17 \pm 2$ & $10 / 06 / 87$ & $30 \pm 3$ & $10 / 16 / 87$ & $33 \pm 3$ \\
\hline $10 / 07 / 88$ & $14 \pm 2$ & $10 / 06 / 88$ & $27 \pm 3$ & $11 / 07 / 88$ & $16 \pm 2$ \\
\hline $9 / 29 / 89$ & $16 \pm 2$ & $10 / 03 / 89$ & $28 \pm 3$ & $10 / 31 / 89$ & $25 \pm 3$ \\
\hline $10 / 17 / 90$ & $14 \pm 2$ & $10 / 03 / 90$ & $20 \pm 3$ & $10 / 25 / 90$ & $17 \pm 2$ \\
\hline $10 / 07 / 91$ & $-3 \pm 2$ & $10 / 15 / 91$ & $15 \pm 3$ & $10 / 08 / 91$ & $14 \pm 2$ \\
\hline
\end{tabular}


LINE OF EQUAL STRONTIUM-90 CONCENTRATION Interval variable; concentration in picocuries per liter

- WELL COMPLETED IN THE SNAKE RIVER PLAIN AQUIFER AND SAMPLED FOR STRONTIUM-90

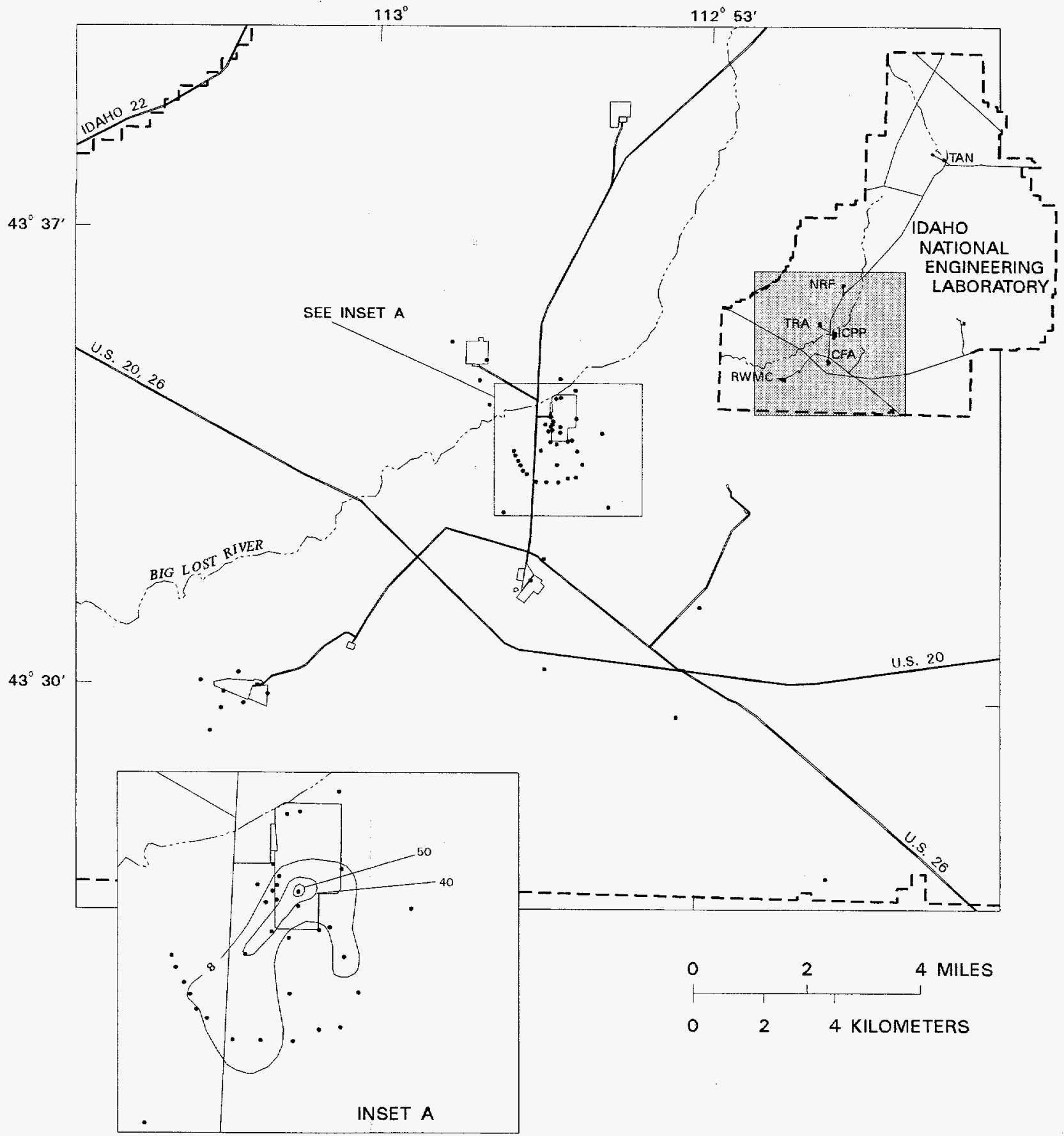

Figure 13.-Distribution of strontium-90 in water from the Snake River Plain aquifer at the Idaho National Engineering Laboratory, October 1991. 
be attributed to discharge of liquid radioactive wastewater only to TRA infiltration ponds and to sorption processes in the unsaturated zone and perched ground-water zones between the land surface and the Snake River Plain aquifer.

\section{Cobalt-60}

During 1952-91, about $435 \mathrm{Ci}$ of cobalt-60 in wastewater was discharged to the TRA radioactive-waste infiltration ponds. Before 1974 , the average disposal rate was about $18 \mathrm{Ci} / \mathrm{yr}$; during 1974-88, the average disposal rate was 2.3 $\mathrm{Ci} / \mathrm{yr}$ (Orr and Cecil, 1991). During 1989-91, about $0.5 \mathrm{Ci}$ of cobalt 60 was discharged to the ponds. The half-life of cobalt-60 is 5.27 years (Walker and others, 1989, p. 25).

Cobalt- 60 concentrations in water from well 65 (fig. 5), south of the TRA, exceeded the reporting level through 1985 but have not been detected since 1985 (Orr and Cecil, 1991, p. 35). The decrease in discharge of cobalt- 60 to the TRA radioactive-waste infiltration ponds, radioactive decay, and sorption processes in the unsaturated and perched ground-water zones may all have contributed to the absence of detectable concentrations of cobalt- 60 in ground water near the TRA since 1985.

Cobalt- 60 concentrations in water from the TAN disposal well (fig. 2) exceeded the reporting level as a result of the discharge of radioactive wastewater to the well before 1972 . The TAN disposal well was tumed over to a DOE contractor in 1988 as part of the Environmental Restoration Program. Samples were collected by the USGS in 1989 for special studies, but have not been collected since 1989. Water from the TAN disposal well contained $170 \pm 40 \mathrm{pCi} / \mathrm{L}$ of cobalt 60 in December 1989. Cobalt-60 also was detected in water from well 14 at a concentration of $0.31 \pm 0.04$ $\mathrm{pCi} / \mathrm{L}$ in September 1989, but was not detected in a replicate sample collected at the same time or in a sample collected in August 1991. During 1989-91, cobalt-60 concentrations in water from all other wells completed in the Snake River Plain aquifer at the INEL were below the reporting level.

\section{Cesium-137}

From 1952 to 1991 , about $138 \mathrm{Ci}$ of cesium137 in wastewater was discharged to the TRA radioactive-waste infiltration ponds and about 23 $\mathrm{Ci}$ was discharged to the ICPP disposal well and infiltration ponds. During 1989-91, about $0.02 \mathrm{Ci}$ was discharged to the TRA radioactive-waste infiltration ponds and $0.13 \mathrm{Ci}$ was discharged to the ICPP infiltration ponds. The half-life of cesium-137 is 30.17 years (Walker and others, 1989, p. 34).

Concentrations of cesium-137 in water from wells 40 and 47 exceeded the reporting levels through 1985, but have been below the reporting level since 1985 (Orr and Cecil, 1991, p. 35). The absence of detectable concentrations of cesium137 is attributed to the discontinuation of wastewater discharge to the ICPP disposal well and to sorption processes in the unsaturated and perched ground-water zones.

Cesium-137 concentrations in water from the TAN disposal well exceeded the reporting level as a result of the discharge of wastewater to the well before 1972. In March 1989, the concentration of cesium-137 in water from the TAN disposal well was $3,170 \pm 150 \mathrm{pCi} / \mathrm{L}$. In December 1989 , the concentration was $4,370 \pm 140 \mathrm{pCi} / \mathrm{L}$. During 1989-91, concentrations of cesium-137 in water from all other wells completed in the Snake River Plain aquifer at the INEL were below the reporting level.

\section{Plutonium}

Monitoring of plutonium-238 and plutonium$239,-240$ (undivided) in wastewater discharged to the Snake River Plain aquifer through the ICPP disposal well began in 1974. Before that time, alpha radioactivity from disintegration of plutonium was not separable from the monitored, undifferentiated alpha radioactivity. During 1974-88, about $0.26 \mathrm{Ci}$ of plutonium was discharged to the disposal well and infiltration ponds at the ICPP (Orr and Cecil, 1991). During 1989-91, about $0.003 \mathrm{Ci}$ of plutonium was discharged to infiltration ponds at the ICPP. The 
half-lives of plutonium-238, plutonium-239, and plutonium-240 are $87.7 ; 24,100$; and 6,560 years, respectively (Walker and others, 1989, p. 46). As a result of disposal of radioactive wastewater in the ICPP disposal well, concentrations of plutonium isotopes in some samples from wells 40 and 47 through January 1987 exceeded the reporting level (Orr and Cecil, 1991, p. 37). Concentrations in samples collected from these wells since 1987 have been below the reporting level.

Plutonium isotopes in water from the TAN disposal well (fig. 2) exceeded the reporting level as a result of disposal of radioactive wastewater prior to 1972. In December 1989, the concentration of plutonium-238 in the TAN disposal well was $0.26 \pm 0.04 \mathrm{pCi} / \mathrm{L}$ and the concentration of plutonium-239, -240 (undivided) was $0.71 \pm 0.06$ $\mathrm{pCi} / \mathrm{L}$. Concentrations of plutonium isotopes in water samples from the TAN disposal well in March 1989 were below the reporting level. During 1989-91, concentrations of plutonium isotopes in water from all other wells completed in the Snake River Plain aquifer at the INEL were below the reporting level.

\section{Americium-241}

Americium-241 is a decay product of plutonium-241. Plutonium isotopes have been detected in wastewater discharged to the Snake River Plain aquifer at the INEL and are in wastes buried at the RWMC. The half-life of americium241 is 432.7 years (Walker and others, 1989 , p. 46). Concentrations of americium-241 in water samples collected between September 1972 and July 1982 from wells $87,88,89$, and 90 at the RWMC (fig. 5), and in water samples collected through 1988 from the TAN disposal well, exceeded the reporting level (Orr and Cecil, 1991, pg. 38-39). During 1989-91, concentrations of americium-241 in water from all the wells completed in the Snake River Plain aquifer at the INEL were below the reporting level.

\section{Chromium}

Wastewater from TRA cooling-tower operations contained an estimated $24,000 \mathrm{lb}$ of chromium that was discharged to an infiltration pond during 1952-64 and an estimated $31,000 \mathrm{lb}$ that was discharged to an injection well during 1965-72 (Mann and Knobel, 1988, p. 7-10). In October 1972, chromium that was used as a corrosion inhibitor in cooling-tower operations was replaced by a polyphosphate. During 1971-83, about $265 \mathrm{lb}$ of chromium was discharged to the ICPP disposal well and $720 \mathrm{lb}$ of chromate was discharged in wastewater at the Power Burst Facility (Cassidy, 1984, p. 3). No chromium disposal was reported at the INEL during 1984-91.

Before October 1989, filtered samples were sent to the RESL for analyses; results were reported as total chromium. Previous reports on hydrologic conditions at the INEL that included a section on total chromium are: Barraclough and others, 1981; Lewis and Jensen, 1984; Pittman and others, 1988; and Orr and Cecil, 1991. In these reports, results actually were for filtered or dissolved chromium. Since October 1989, the NWQL have analyzed water samples for chromium. From October 1989 through July 1990, analyses for total recoverable chromium were requested. Since July 1990, analyses for dissolved chromium and dissolved hexavalent chromium have been requested. During 1989-91, several studies at the INEL included analyses of either total chromium or dissolved chromium and hexavalent chromium. Concentrations of the various chromium species are given in Liszewski and Mann (1993, table 4).

Concentrations of dissolved chromium and hexavalent chromium were monitored in water samples from 24 wells in 1991 as part of the regular monitoring program. The MCL of $50 \mu \mathrm{g} / \mathrm{L}$ (U.S. Environmental Protection Agency, 1989, p. 547) for total chromium in drinking water was exceeded in water from one well. Concentrations of dissolved chromium and hexavalent chromium in well 65 were 200 and $170 \mu \mathrm{g} / \mathrm{L}$, respectively. Other water samples contained from less than 1 to $30 \mu \mathrm{g} / \mathrm{L}$ of dissolved chromium and from less than 1 to $21 \mu \mathrm{g} / \mathrm{L}$ of hexavalent chromium. Background concentrations of dissolved chromium in the Snake 
River Plain aquifer range from $2-3 \mu \mathrm{g} / \mathrm{L}$ (Orr and others, 1991, p. 41).

\section{Sodium}

During 1986-88, an estimated 3.2 million $\mathrm{lb}$ of sodium in wastewater was discharged at the INEL (Orr and Cecil, 1991). During 1989-91, an estimated 4.4 million $\mathrm{lb}$ of sodium was discharged. This included about 2.3 million $\mathrm{lb}$ of sodium estimated from chloride disposal records to have been discharged to the ICPP infiltration ponds. About $518,000 \mathrm{lb}$ of sodium was discharged to the TRA infiltration ponds, about $262,000 \mathrm{lb}$ was discharged to the NRF industrial-waste ditch, and about 1.2 million $\mathrm{lb}$ was discharged at the CFA.

The background sodium concentration in water from the Snake River Plain aquifer near the INEL generally is less than $10 \mathrm{mg} / \mathrm{L}$ (Robertson and others, 1974, p. 155). In October 1991, most of the wells in the southern part of the INEL had concentrations greater than $10 \mathrm{mg} / \mathrm{L}$. The increase in sodium concentrations may be attributed to increased disposal rates and a lack of recharge from the Big Lost River. The largest concentration in water samples from wells at the INEL was $75 \mathrm{mg} / \mathrm{L}$ in a sample from well 59 (fig. 5) which may be attributed to seepage down the well from the perched zone beneath the ICPP infiltration pond. In 1991, sodium concentrations in water from wells 88 and 120 (fig. 5), near the RWMC, contained 45 and $31 \mathrm{mg} / \mathrm{L}$ of sodium, respectively. Water from one well, MTR Test, at the TRA, contained a sodium concentration of $22 \mathrm{mg} / \mathrm{L}$.

\section{Chloride}

About 5.3 million $1 \mathrm{~b}$ of chloride was discharged to infiltration ponds at the INEL during 1989-91, which is an increase from the estimated 3.96 million $\mathrm{lb}$ discharged during 1986-88 (Orr and Cecil, 1991). Of the 5.3 million lb discharged during 1989-91, about 3.6 million $\mathrm{lb}$ was discharged to the ICPP infiltration ponds (fig. 3). The increase in chloride disposal has resulted in increases in chloride concentrations in water samples from the Snake River Plain aquifer.
In 1991, chloride concentrations in most water samples from the ICPP, RWMC, and NRF (fig. 14) exceeded $20 \mathrm{mg} / \mathrm{L}$. At the ICPP, the area of the chloride plume with concentrations exceeding $20 \mathrm{mg} / \mathrm{L}$ increased during 1989-91. In 1988, the area of the chloride plume was about $9.5 \mathrm{mi}^{2}$ (Orr and Cecil, 1991, p. 42) and did not extend as far south as Highway 20. In 1991, the area of the chloride plume was about $15 \mathrm{mi}^{2}$ and extended south of Highway 20 (fig. 14). Chloride concentrations in water from wells 113 (fig. 5) and CFA-1 (fig. 4) were 170 and $100 \mathrm{mg} / \mathrm{L}$, respectively. The increase in the extent of the plume may be attributed to the increased disposal rates at the ICPP and the lack of recharge from the Big Lost River. At the TRA, the chloride concentration in water from well 65 was $22 \mathrm{mg} / \mathrm{L}$. Chloride concentrations in water from other wells completed in the Snake River Plain aquifer at the TRA were less than $20 \mathrm{mg} / \mathrm{L}$. At the RWMC, chloride concentrations in water from wells 88,89 , and 120 were 90,42 , and $29 \mathrm{mg} / \mathrm{L}$, respectively. Chloride concentrations in water from wells near the NRF slightly exceeded $20 \mathrm{mg} / \mathrm{L}$, except for the concentrations in INEL-1-WS well (fig. 4), which was $120 \mathrm{mg} / \mathrm{L}$. The secondary MCL for chloride in drinking water is $250 \mathrm{mg} / \mathrm{L}$ (U.S. Environmental Protection Agency, 1989, p. 656).

\section{Sulfate}

About 4.13 million $\mathrm{lb}$ of sulfate was discharged to infiltration ponds at the INEL during 1989-91. Of this amount, about 2.76 million lb was discharged to infiltration ponds at the TRA; $575,000 \mathrm{lb}$ was discharged to infiltration ponds at the ICPP; and 525,000 lb was discharged to the NRF industrial-waste ditch. The background concentrations of sulfate in the Snake River Plain aquifer in the south-central part of the INEL range from about 10 to $40 \mathrm{mg} / \mathrm{L}$ (Robertson and others, 1974, p. 72).

Sulfate concentrations in water at the INEL are not monitored routinely because they generally have been at background levels. Because of expanded laboratory schedules from October 1990 through January 1991, and because of special studies, sulfate concentrations in some samples 


\section{EXPLANATION}

LINE OF EQUAL CHLORIDE CONCENTRATION Interval variable, concentration in milligrams per liter

WELL COMPLETED IN THE SNAKE RIVER PLAIN AOUIFER AND SAMPLED FOR CHLORIDE

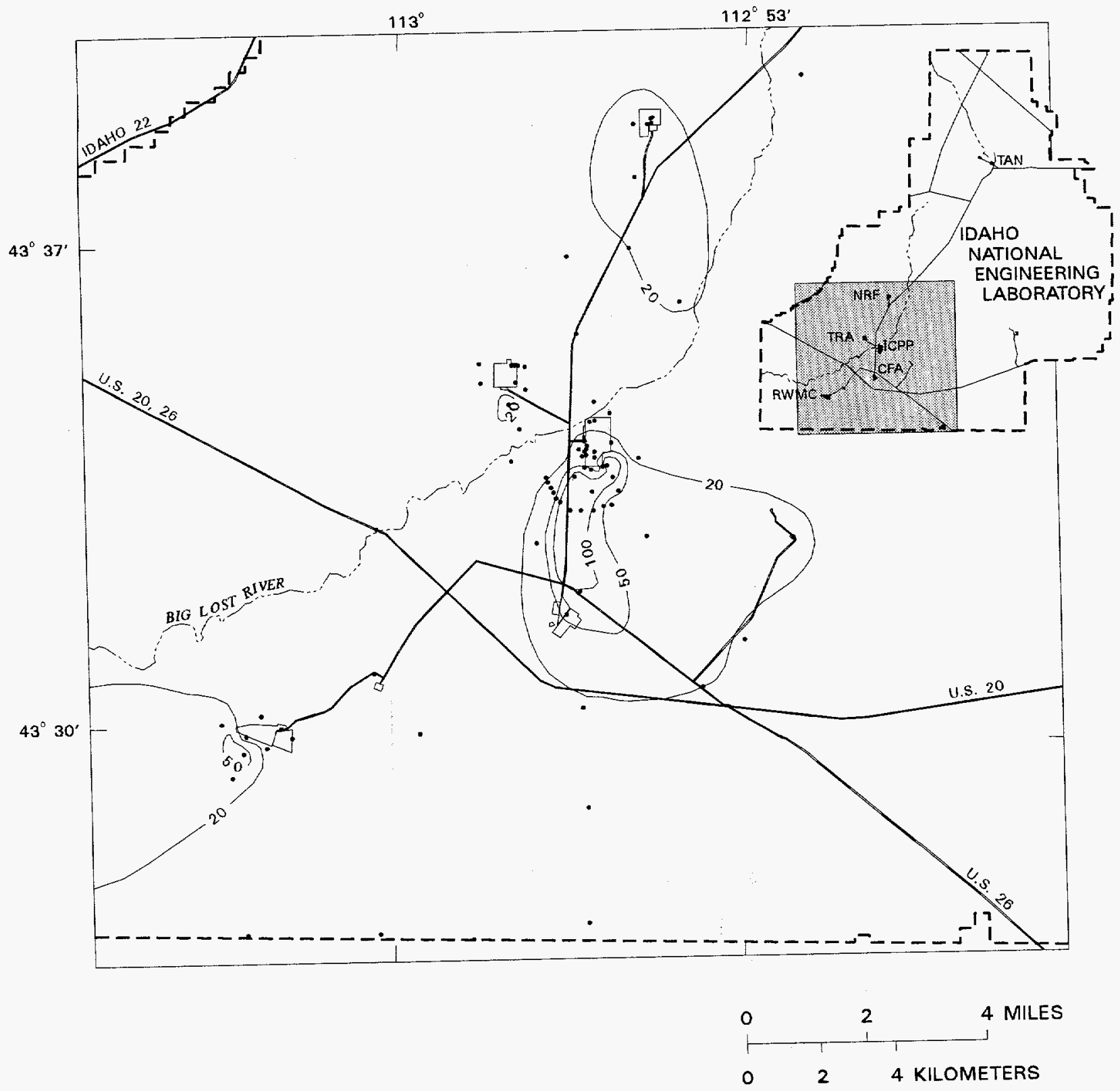

Figure 14. Distribution of chloride in water from the Snake River Plain aquifer at the Idaho National Engineering Laboratory, October 1991. 
from wells at the INEL were determined during 1989-91.

Sulfate concentrations in water from two wells near the NRF, two wells near the TRA, and one well near the RWMC were larger than background concentrations. Water collected in September 1991 from well NRF-6 contained $240 \mathrm{mg} / \mathrm{L}$, and water collected in October 1990 from INEL-1-WS contained $54 \mathrm{mg} / \mathrm{L}$. The large concentration in NRF-6 may be attributed to its proximity to the NRF waste ditch. October 1990 water samples from MTR-Test and well 65 contained 87 and $150 \mathrm{mg} / \mathrm{L}$ of sulfate, respectively. The larger concentrations in these wells probably are due to sulfate disposal at the TRA infiltration ponds. A January 1991 water sample from well 88, near the RWMC, contained $62 \mathrm{mg} / \mathrm{L}$ of sulfate. The larger concentration in this well may be attributed to the well construction and/or waste disposal at the RWMC (Pittman and others, 1988 , p. 57-58). The secondary MCL for sulfate in drinking water is $250 \mathrm{mg} / \mathrm{L}$ (U.S. Environmental Protection Agency, 1989, p. 656).

\section{Nitrate}

Wastewater containing nitrate was injected into the Snake River Plain aquifer through the ICPP disposal well from 1952 to February 1984 and to the ICPP infiltration ponds after February 1984 (Orr and Cecil, 1991). An average of 56,000 lb of nitrate was discharged annually to the ICPP infiltration ponds during 1989-91. This rate of disposal is about 35 percent of the disposal rate during 1986-88 and 20 percent of the rate during 1979-85. Concentrations of nitrate in ground water not affected by wastewater disposal from INEL facilities generally are less than $5 \mathrm{mg} / \mathrm{L}$ as nitrate (Robertson and others, 1974, p. 73).

Nitrate concentrations reported by the NWQL as nitrogen have been converted to nitrate in this report for comparison with nitrate concentrations presented in previous reports. Nitrate concentrations and the area and configuration of the nitrate plume have changed in response to disposal-rate changes and to the diversion of wastewater from the ICPP disposal well to infiltration ponds in 1984. In 1981, the area of the ICPP nitrate plume in which concentrations exceeded $5 \mathrm{mg} / \mathrm{L}$ was about $10 \mathrm{mi}^{2}$ and the maximum concentration was $62 \mathrm{mg} / \mathrm{L}$ in water from well 43 (Lewis and Jensen, 1984, p. 58). By 1984, the area had increased to about $14 \mathrm{mi}^{2}$ and concentrations ranged from less than 5 to $26.9 \mathrm{mg} / \mathrm{L}$ (Pittman and others, 1988, p. 61). By 1988, the area had decreased to about $5 \mathrm{mi}^{2}$ (Orr and Cecil, 1991, p. 44-45). In 1991, the area remained about the same as in 1988 (fig. 15). Nitrate concentrations in samples from wells 43 , 67, 77, and CFA-1 (figs. 4 and 5) were 44, 17, 22, and $18 \mathrm{mg} / \mathrm{L}$, respectively. Nitrate concentrations remained relatively constant during 1989-91 even though disposal rates decreased. This may be attributed to lack of recharge from the Big Lost River.

In 1991, nitrate concentrations in water samples from wells 88,89 , and 119 , near the RWMC, were $5.3,8.0$, and $6.2 \mathrm{mg} / \mathrm{L}$, respectively. Historically, concentrations in water near the RWMC have slightly exceeded the regional background concentration of about $5 \mathrm{mg} / \mathrm{L}$ (Orr and Cecil, 1991). At the TRA, water from well 65 and the MTR Test well contained 6.6 and $5.3 \mathrm{mg} / \mathrm{L}$ of nitrate, respectively. Water from well 97 , south of the $\mathrm{NRF}$, contained $8.4 \mathrm{mg} / \mathrm{L}$. Concentrations of nitrate in water from the Snake River Plain aquifer at the INEL did not exceed the MCL for drinking water of $44 \mathrm{mg} / \mathrm{L}$ (as nitrate) (U.S. Environmental Protection Agency, 1989, p. 547).

\section{Lead and Mercury}

Before 1984, about $535 \mathrm{lb}$ of lead and $140 \mathrm{lb}$ of mercury in wastewater was discharged, principally at the ICPP. During 1989-91, no lead or mercury was discharged to infiltration ponds at the INEL.

During 1989-91, water samples from 84 wells completed in the Snake River Plain aquifer were analyzed for lead as part of various sampling programs at the INEL (Liszewski and Mann, 1993). Water samples from 57 wells contained lead concentrations less than the reporting levels of 1,5 , or $10 \mu \mathrm{g} / \mathrm{L}$. The reporting level for chemical constituents is the lowest measured concentration of a constituent that may be reliably reported using a given analytical method (Pritt and Jones, 1989). 


\section{EXPLANATION}

LINE OF EQUAL NITRATE CONCENTRATION Interval variable, concentration in milligrams per liter as nitrate

WELL COMPLETED IN THE SNAKE RIVER PLAIN AQUIFER AND SAMPLED FOR NITRATE

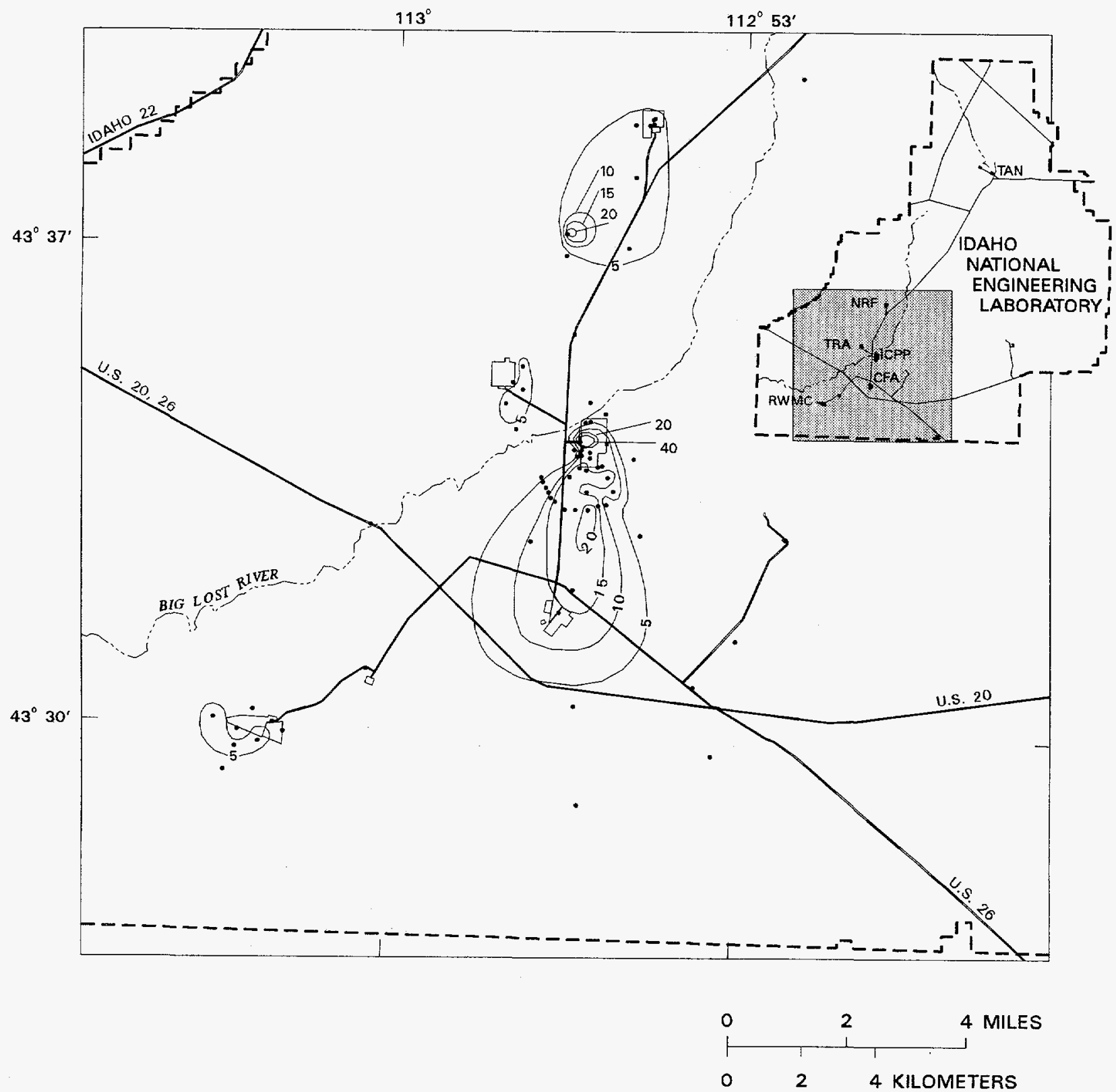

Figure 15. Distribution of nitrate in water from the Snake River Plain aquifer at the Idaho National Engineering Laboratory, October 1991. 
Lead concentrations in water samples from the remaining 27 wells ranged from 1 to $30 \mu \mathrm{g} / \mathrm{L}$ and were less than the maximum contaminant level of $50 \mu \mathrm{g} / \mathrm{L}$ (U.S. Environmental Protection Agency, 1989 , p. 547).

As part of the same sampling programs, water samples from 73 wells completed in the aquifer were analyzed for mercury. Water samples from 59 wells contained less than $0.1 \mu \mathrm{g} / \mathrm{L}$. The maximum mercury concentration was $0.5 \mu \mathrm{g} / \mathrm{L}$ in a water sample from well 47. Mercury concentrations in water samples from the remaining 13 wells ranged from 0.1 to $0.3 \mu \mathrm{g} / \mathrm{L}$; the MCL for mercury in drinking water is $2 \mu \mathrm{g} / \mathrm{L}$ (U.S. Environmental Protection Agency, 1989, p. 547).

\section{Purgeable Organic Compounds}

Purgeable organic compounds (POC's) are present in the Snake River Plain aquifer as a result of waste-disposal practices at the INEL. In 1987, water samples from 81 wells completed in the Snake River Plain aquifer were analyzed for 36 POC's as part of a reconnaissance sampling program (Mann and Knobel, 1987). Analyses of samples indicated that at least 1 of 12 POC's was present in samples from several wells at concentraions above their reporting level. In 1988 and 1989 , water samples were collected from 38 wells as a continuation of the 1987 study (Mann, 1990). Water samples from 22 wells contained concentrations above the reporting level for at least 1 of 19 POC's, mainly carbon tetrachloride; 1,1,1trichloroethane; and trichloroethylene. In 1990 and 1991, water samples were collected from 76 wells at or near the INEL for various water-quality studies (Liszewski and Mann, 1992). Water samples from 31 wells completed in the Snake River Plain aquifer contained concentrations above the reporting level for at least 1 of 14 POC's.

A plume of 1,1,1-trichloroethane, which is a solvent used in industrial cleaning processes (Lucius and others, 1989, p. 450), has developed in the Snake River Plain aquifer near the ICPP as a result of waste disposal practices (fig. 16). Concentrations of 1,1,1-trichloroethane in water samples from selected wells near the ICPP are given in table 4 . The concentrations are all below the MCL for drinking water of $200 \mu \mathrm{g} / \mathrm{L}$ (U.S. Environmental Protection Agency, 1989, p. 608).

During 1987-91, concentrations of POC's in water samples from several wells near the RWMC exceeded the reporting levels. For example, in October 1991, water from the RWMC Production well contained $2.2 \mu \mathrm{g} / \mathrm{L}$ of carbon tetrachloride, $0.3 \mu \mathrm{g} / \mathrm{L}$ of chloroform, $0.4 \mu \mathrm{g} / \mathrm{L}$ of $1,1,1-$ trichloroethane, and $1.0 \mu \mathrm{g} / \mathrm{L}$ of trichloroethylene. Water from well 87 contained concentrations above the reporting levels of carbon tetrachloride; 1,1,1-trichloroethane; and trichloroethylene. Well 88 contained concentrations above the reporting levels of carbon tetrachloride; chloroform; 1,1,1trichloroethane; and trichloroethylene. Well 90 contained concentrations above the reporting levels of carbon tetrachloride; 1,1,1-trichloroethane; trichloroethylene; and dichlorodifluoromethane. Well 120 contained concentrations above the reporting levels of carbon tetrachloride and trichloroethylene (Liszewski and Mann, 1992). The POC's are present as a result of waste-disposal practices at the RWMC.

During 1987-89, concentrations of POC's in water from several wells near the TAN exceeded the reporting levels. The wells were not sampled by the USGS for POC's during 1990-91 because the wells were not part of routine sampling. Water samples collected in 1989 from seven wells at and near the TAN contained from 0.3 to $24,000 \mu \mathrm{g} / \mathrm{L}$ of trichloroethylene. Water samples from five wells contained from 0.7 to $64 \mu \mathrm{g} / \mathrm{L}$ of tetrachloroethylene. Concentrations of 11 other POC's also have been detected in wells near the TAN (Mann, 1990).

\section{Specific Conductance, Temperature, and $\mathrm{pH}$}

Specific conductance is a measure of the electrical conductivity of water and is proportional to the quantities of dissolved chemical constituents in the water. Dissolved chemical constituents, such as chloride, sodium, and sulfate, in wastewater discharged to disposal wells and infiltration ponds at INEL facilities generally have increased specific 


\section{EXPLANATION}

LIMIT OF AREA IN WHICH 1,1,1-

TRICHLOROETHANE CONCENTRATIONS EXCEEDED

THE REPORTING LEVEL OF 0.2 MICROGRAMS

PER LITER--Approximately located. Data

collected during 1987-91.

WELL COMPLETED IN THE SNAKE RIVER

PLAIN AQUIFER AND SAMPLED FOR

1,1,1-TRICHLOROETHANE

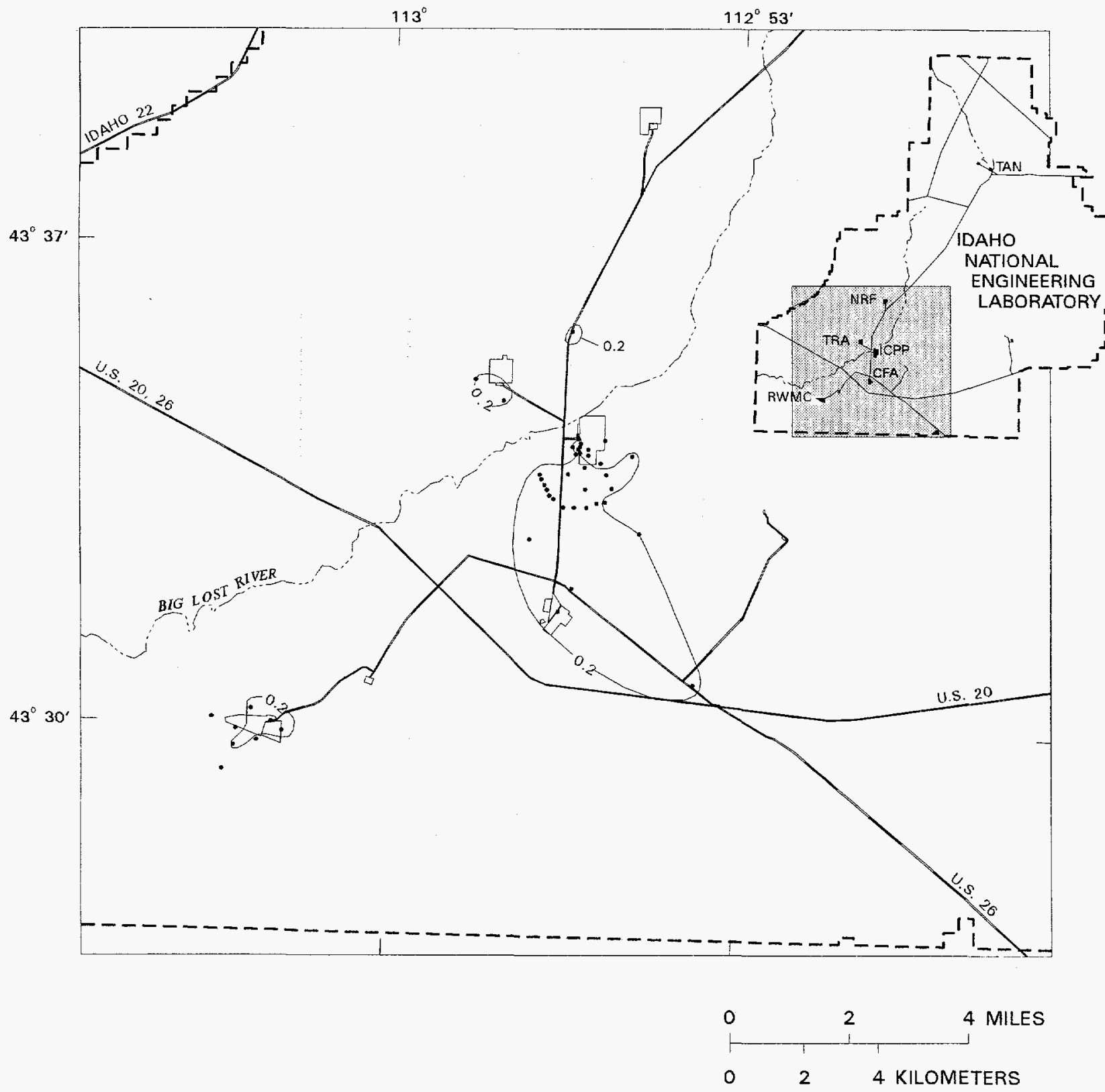

Figure 16. Distribution of 1,1,1-trichloroethane in water from the Snake River Plain aquifer at the Idaho National Engineering Laboratory, 1987 to 1991. 
Table 4. Concentrations of 1,1,1-trichloroethane in water from selected wells at the Idaho National Engineering Laboratory, 1987-91

[Concentrations in micrograms per liter. Location of wells shown on figures 4 and 5.<, indicates concentration is less than the reporting level of 0.2 micrograms per liter]

\begin{tabular}{|c|c|c|c|c|c|}
\hline Well & Date sampled & Concentration & Well & Date sampled & Concentration \\
\hline 20 & $5 / 30 / 91$ & 0.2 & 59 & $10 / 06 / 87$ & $<.2$ \\
\hline 34 & $10 / 02 / 90$ & .4 & 65 & $10 / 14 / 87$ & 1.1 \\
\hline 35 & $10 / 25 / 90$ & .4 & & $5 / 16 / 91$ & .5 \\
\hline 36 & $10 / 25 / 90$ & .4 & 67 & $10 / 06 / 87$ & .6 \\
\hline 37 & $10 / 05 / 87$ & .7 & 77 & $10 / 25 / 90$ & .6 \\
\hline 38 & $10 / 05 / 90$ & .6 & 79 & $10 / 01 / 90$ & .2 \\
\hline 39 & $10 / 25 / 90$ & .3 & 82 & $10 / 06 / 87$ & .3 \\
\hline 40 & $10 / 13 / 87$ & .3 & 85 & $6 / 04 / 91$ & .3 \\
\hline 41 & $10 / 16 / 90$ & $<.2$ & 111 & $9 / 25 / 87$ & .3 \\
\hline 42 & $10 / 16 / 90$ & $<.2$ & 1.12 & $9 / 25 / 87$ & .6 \\
\hline \multirow[t]{2}{*}{43} & $10 / 05 / 87$ & .2 & & $9 / 28 / 88$ & .6 \\
\hline & $6 / 21 / 88$ & $<.2$ & & $5 / 13 / 91$ & .4 \\
\hline 44 & $10 / 26 / 90$ & .2 & 113 & $10 / 02 / 87$ & .8 \\
\hline 45 & $10 / 26 / 90$ & .2 & 114 & $10 / 09 / 87$ & 1.1 \\
\hline 46 & $10 / 26 / 90$ & .2 & 115 & $10 / 09 / 87$ & $<.2$ \\
\hline \multirow[t]{2}{*}{47} & $10 / 26 / 87$ & $<.2$ & 116 & $10 / 28 / 87$ & .4 \\
\hline & $9 / 30 / 88$ & $<.2$ & Badging Facility & $10 / 24 / 87$ & 1.0 \\
\hline 48 & $10 / 31 / 90$ & $<.2$ & CFA-1 & $10 / 15 / 87$ & .8 \\
\hline 51 & $10 / 13 / 87$ & .7 & & $6 / 19 / 91$ & .4 \\
\hline 52 & $10 / 16 / 90$ & $<.2$ & CFA-2 & $10 / 14 / 87$ & .7 \\
\hline \multirow[t]{2}{*}{57} & $10 / 09 / 87$ & .5 & Fire Station-2 & $11 / 03 / 87$ & 2.6 \\
\hline & $5 / 13 / 91$ & .4 & & $6 / 19 / 91$ & 2.0 \\
\hline
\end{tabular}


conductance of ground water. In October 1991, the specific conductance of water from 100 wells at the INEL ranged from 254 to $1,380 \mu \mathrm{S} / \mathrm{cm}$; the median specific conductance was $425 \mu \mathrm{S} / \mathrm{cm}$.

The increase in specific conductance attributed to wastewater discharged to the aquifer is apparent in ground water downgradient from INEL facilities. In October 1991, the area near the ICPP, TRA, and NRF in which the specific conductance of water from wells exceeded $400 \mu \mathrm{S} / \mathrm{cm}$ was about $25 \mathrm{mi}^{2}$ (fig. 17), about the same as in 1988 (Orr and Cecil, 1991, p. 45). A plume of increased specific conductance originated from the ICPP infiltration ponds and extended downgradient from the ICPP to the CFA. The specific conductance of water from several wells within this plume increased from about $500 \mu \mathrm{S} / \mathrm{cm}$ in 1985 (Pittman and others, 1988, p. 64) to more than $900 \mu \mathrm{S} / \mathrm{cm}$ in 1991; water from well 113 (fig. 5) had a specific conductance of $905 \mu \mathrm{S} / \mathrm{cm}$ in 1991. Increases in specific conductance probably can be attributed to the increase of disposal of chemical wastewater to the ICPP infiltration ponds in 1989-91 and to the lack of recharge from the Big Lost River.

The specific conductance of water from several wells at the TRA exceeded $400 \mu \mathrm{S} / \mathrm{cm}$ in 1991 . Water from well 65, downgradient from infiltration ponds at the TRA, had a specific conductance of $608 \mu \mathrm{S} / \mathrm{cm}$. The specific conductance of water from wells near the NRF generally exceeded $500 \mu \mathrm{S} / \mathrm{cm}$. Water from well NRF-6, near the industrial waste ditch, had a specific conductance of $1,380 \mu \mathrm{S} / \mathrm{cm}$. Water from wells 88 and 120 , near the RWMC, had specific conductances exceeding $400 \mu \mathrm{S} / \mathrm{cm}$.

Water temperatures of 100 samples collected in 1991 ranged from $10^{\circ} \mathrm{C}$ in wells 86 and $\mathrm{P} \& W-2$ to $19^{\circ} \mathrm{C}$ in wells EBR-1 and 22. The median temperature was $13^{\circ} \mathrm{C}$. The $\mathrm{pH}$ ranged from 7.4 in well Cerro Grande to 8.5 in well NRF-7; the median pH was 8.0.

\section{SUMMARY}

In 1991, the altitude of the water table in the Snake River Plain aquifer at the INEL was about
$4,585 \mathrm{ft}$ above sea level near TAN and about 4,425 $\mathrm{ft}$ above sea level near the RWMC. Locally, the hydraulic gradient ranged from about 1 to $15 \mathrm{ft} / \mathrm{mi}$ and flow was to the south and southwest. From April-August 1988 to April-August 1991, water levels in INEL wells declined; declines ranged from about $10 \mathrm{ft}$ in a well in the central part of the INEL to about $2 \mathrm{ft}$ in wells in the southeastern part.

During 1989-91, about $2.7 \mathrm{Ci}$ of tritium was discharged to infiltration ponds at the ICPP and about $470 \mathrm{Ci}$ was discharged to radioactive-waste infiltration ponds at the TRA. A tritium plume originating from the ICPP and TRA decreased from $45 \mathrm{mi}^{2}$ in 1988 to about $40 \mathrm{mi}^{2}$ in 1991. The area of the plume containing tritium concentrations in excess of $20 \mathrm{pCi} / \mathrm{mL}$ decreased from 2.8 to 2.4 $\mathrm{mi}^{2}$. Tritium concentrations in wells 65 and 77 were $37.8 \pm 0.8$ and $41.7 \pm 0.9 \mathrm{pCi} / \mathrm{mL}$, respectively. Near the southern boundary of the INEL, tritium concentrations in water from wells 103,105, and 108 exceeded the reporting level during 1983-85, but have been less than the reporting level since 1985. Radioactive decay, decreased tritium disposal, and discontinuation of the use of the ICPP disposal well and subsequent wastewater discharge to infiltration ponds contributed to decreased concentrations of tritium in ground water at the INEL during 1989-91.

About $0.08 \mathrm{Ci}$ of strontium-90 was discharged to infiltration ponds at the INEL during 1989-91. In October 1991, strontium-90 concentrations in ground water ranged from $9 \pm 3$ to $55 \pm 4 \mathrm{pCi} / \mathrm{L}$. During 1989-91, strontium-90 concentrations remained relatively constant because of the lack of recharge from the Big Lost River and because of increased disposal of other chemical constituents in the infiltration ponds that may have affected the exchange capacity in the unsaturated zone. The absence of a strontium-90 plume at the TRA can be attributed to disposal of radioactive wastewater only to TRA infiltration ponds and to sorption processes in the unsaturated and perched groundwater zones.

During 1989-91, about $0.5 \mathrm{Ci}$ of cobalt-60 was discharged to TRA radioactive-waste infiltration ponds. In 1985, cobalt-60 was detected in water from well 65 , south of the TRA, but concentrations 
400 — LINE OF EQUAL SPECIFIC CONDUCTANCE Interval 100 microsiemens per centimeter

- WELL COMPLETED IN THE SNAKE RIVER PLAIN AQUIFER

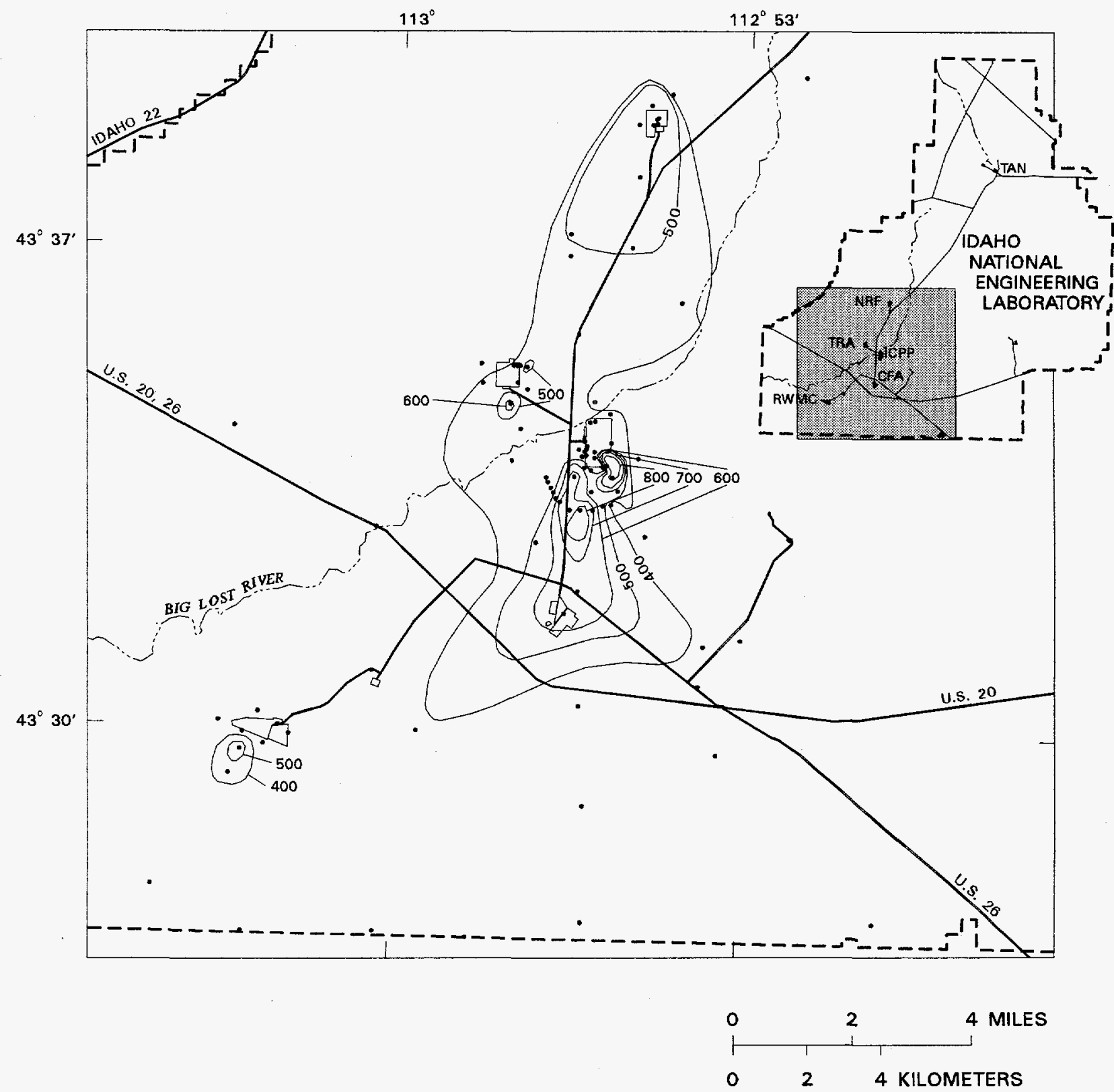

Figure 17. Distribution of specific conductance in water from the Snake River Plain aquifer at the Idaho National Engineering Laboratory, October 1991. 
in subsequent samples were less than the reporting level. The decrease in discharge of cobalt- 60 to the TRA radioactive-waste infiltration ponds, radioactive decay, and sorption processes in the unsaturated zone are responsible for the absence of detectable concentrations of cobalt-60 in ground water near the TRA since 1985 . Water from the TAN disposal well contained $170 \pm 40 \mathrm{pCi} / \mathrm{L}$ of cobalt-60 in December 1989. Cobalt-60 was detected in water from well 14 in September 1989, but was not detected in a replicate sample or from a sample collected later. Cobalt-60 was not detected during 1989-91 in water from all other wells completed in the Snake River Plain aquifer at the INEL.

During 1989-91, about $0.02 \mathrm{Ci}$ of cesium-137 was discharged to the TRA radioactive-waste infiltration ponds and $0.13 \mathrm{Ci}$ was discharged to the ICPP infiltration ponds. Through 1985, cesium-137 was detected in water from wells near the ICPP; since 1985, cesium-137 has not been detected. The absence of detectable concentrations of cesium-137 is attributed to changes in ICPP waste-disposal practices and to sorption processes in the unsaturated and perched ground-water zones. The concentration of cesium-137 in water from the TAN disposal well was $3,170 \pm 150 \mathrm{pCi} / \mathrm{L}$ in March 1989 and 4,370 $\pm 140 \mathrm{pCi} / \mathrm{L}$ in December 1989. Concentrations of cesium-137 were not detected during 1989-91 in water from all other wells completed in the Snake River Plain aquifer.

During 1989-91, about $0.003 \mathrm{Ci}$ of plutonium was discharged to infiltration ponds at the ICPP. Concentrations of plutonium isotopes in some samples from wells 40 and 47 collected through January 1987 exceeded the reporting level; concentrations in samples collected since 1987 have been below the reporting level. In December 1989 , the concentrations of plutonium-238 and plutonium-239, -240 (undivided) in the TAN disposal well were $0.26 \pm 0.04$ and $0.71 \pm 0.06 \mathrm{pCi} / \mathrm{L}$, respectively. Concentrations of plutonium isotopes were below the reporting level in water samples collected from the TAN disposal well in March 1989 and did not exceed the reporting level in any other well completed in the Snake River Plain aquifer at the INEL during 1989-91. During 1989-91, the concentrations of americium-241, a decay product of plutonium-241, in water from all wells completed in the Snake River Plain aquifer at the INEL were below the reporting level.

No chromium disposal was reported at the INEL during 1989-91. In 1991, water samples from 24 wells were sampled for dissolved and hexavalent chromium. The maximum contaminant level of $50 \mu \mathrm{g} / \mathrm{L}$ was exceeded in water samples from well 65 , which had concentrations of 200 and $170 \mu \mathrm{g} / \mathrm{L}$ of dissolved and hexavalent chromium, respectively. Water samples from the other wells contained from less than 1 to $30 \mu \mathrm{g} / \mathrm{L}$ of dissolved chromium and from less than 1 to $21 \mu \mathrm{g} / \mathrm{L}$ of hexavalent chromium.

An estimated 4.4 million lb of sodium in wastewater was discharged at the INEL during 1989-91, principally to the ICPP infiltration ponds. Most of the wells in the southern part of the INEL had concentrations greater than $10 \mathrm{mg} / \mathrm{L}$ in October 1991. During 1989-91, sodium concentrations increased because of an increase in disposal rates and a decrease in recharge. The largest sodium concentration in water from wells was $75 \mathrm{mg} / \mathrm{L}$.

About 5.3 million $\mathrm{lb}$ of chloride in wastewater was discharged during 1989-91. In 1991, cliloride concentrations in several water samples from the ICPP, RWMC, and NRF exceeded $20 \mathrm{mg} / \mathrm{L}$. The ICPP chloride plume, which was $9.5 \mathrm{mi}^{2}$ in 1988 , increased to about $15 \mathrm{mi}^{2}$ in 1991 . Chloride concentrations in water from wells 113 and CFA-1 were 170 and $100 \mathrm{mg} / \mathrm{L}$, respectively. Chloride concentrations in water from aquifer wells at the TRA generally were less than $20 \mathrm{mg} / \mathrm{L}$. Chloride concentrations in water from wells near the NRF slightly exceeded $20 \mathrm{mg} / \mathrm{L}$, except for the concentration in the INEL-1-WS well, which was $120 \mathrm{mg} / \mathrm{L}$.

About 4.13 million lb of sulfate was discharged to infiltration ponds at the INEL during 1989-91. During 1990-91, sulfate concentrations in water from two wells near the NRF, two wells near the TRA, and one well near the RWMC exceeded $40 \mathrm{mg} / \mathrm{L}$, the estimated background concentration of sulfate in the Snake River Plain aquifer at the INEL. 
An average of $56,000 \mathrm{lb}$ of nitrate was discharged annually to the ICPP infiltration ponds during 1989-91. Nitrate concentrations remained relatively constant during 1989-91 even though disposal rates were reduced. Nitrate concentrations in wells 43, 67, 77, and CFA-1 were 44, 17, 22, and $18 \mathrm{mg} / \mathrm{L}$, respectively, in 1991 .

About $535 \mathrm{lb}$ of lead and $140 \mathrm{lb}$ of mercury in wastewater was discharged at the INEL prior to 1984 , principally at the ICPP. During 1989-91, no lead or mercury was reported in wastewater discharge. During 1989-91, lead concentrations in water samples from 57 wells were less than the reporting levels of 1,5 , or $10 \mu \mathrm{g} / \mathrm{L}$. Lead concentrations in water from 27 wells ranged from 1 to $30 \mu \mathrm{g} / \mathrm{L}$ and were less than the maximum contaminant level of $50 \mu \mathrm{g} / \mathrm{L}$. In 1989-91, mercury concentrations in water from 59 wells were less than $0.1 \mu \mathrm{g} / \mathrm{L}$. The mercury concentration in well 47 was $0.5 \mu \mathrm{g} / \mathrm{L}$. Mercury concentrations in water from 13 other wells ranged from 0.1 to $0.3 \mu \mathrm{g} / \mathrm{L}$.

During 1987-91, concentrations of 19 different purgeable organic compounds were detected in water from wells at the INEL. Plumes of 1,1,1trichloroethane have developed in the Snake River Plain aquifer near the ICPP and RWMC as a result of waste disposal practices. In addition to 1,1,1trichloroethane, the RWMC wells also contain concentrations of carbon tetrachloride, chloroform, trichloroethylene, and dichlorodifluoromethane. Water samples from seven wells at and near the TAN contained from 0.3 to $24,000 \mu \mathrm{g} / \mathrm{L}$ of trichloroethylene, water samples from five wells contained from 0.7 to $64 \mu \mathrm{g} / \mathrm{L}$ of tetrachloroethylene.

\section{SELECTED REFERENCES}

Ackerman, D.J., 1991, Transmissivity of the Snake River Plain aquifer at the Idaho National Engineering Laboratory, Idaho: U.S. Geological Survey Water-Resources Investigations Report 91-4058 (DOE/ID-22097), 35 p.
Anderson, S.R., 1991, Stratigraphy of the unsaturated zone and uppermost part of the Snake River Plain aquifer at the Idaho Chemical Processing Plant and Test Reactors Area, Idaho National Engineering Laboratory, Idaho: U.S. Geological Survey WaterResources Investigations Report 91-4010 (DOE/ID-22095), $71 \mathrm{p}$.

Anderson, S.R., and Lewis, B.D., 1989, Stratigraphy of the unsaturated zone at the Radioactive Waste Management Complex, Idaho National Engineering Laboratory, Idaho: U.S. Geological Survey Water-Resources Investigations Report 89-4065 (DOE/ID-22080), 54 p.

Barraclough, J.T., and Jensen, R.G., 1976, Hydrologic data for the Idaho National Engineering Laboratory site, Idaho, 1971 to 1973: U.S. Geological Survey Open-File Report 75-318 (IDO-22055), 52 p.

Barraclough, J.T., Lewis, B.D., and Jensen, R.G., 1981, Hydrologic conditions at the Idaho National Engineering Laboratory, Idaho, emphasis: 1974-1978: U.S. Geological Survey Water-Resources Investigations Open-File Report 81-526 (IDO-22060), $116 \mathrm{p}$.

Barraclough, J.T., Robertson, J.B., and Janzer, V.J., 1976, Hydrology of the solid waste burial ground, as related to the potential migration of radionuclides, Idaho National Engineering Laboratory, with a section on Drilling and sample analyses, by L.G. Saindon: U.S. Geological Survey Open-File Report 76-471 (IDO-22056), 183 p.

Barraclough, J.T., Teasdale, W.E., and Jensen, R.G., 1967, Hydrology of the National Reactor Testing Station, Idaho, 1965: U.S. Geological Survey Open-File Report (IDO-22048), $107 \mathrm{p}$.

Barraclough, J.T., Teasdale, W.E., Robertson, J.B., and Jensen, R.G., 1967, Hydrology of the National Reactor Testing Station, Idaho, 1966: U.S: Geological Survey Open-File Report (IDO-22049), 95 p. 
Bartholomay, R.C., 1990a, Digitized geophysical logs for selected wells on or near the Idaho National Engineering Laboratory, Idaho: U.S. Geological Survey Open-File Report 90-366 (DOE/ID-22088), 347 p.

---- 1990b, Mineralogical correlation of surficial sediment from area drainages with selected sedimentary interbeds at the Idaho National Engineering Laboratory, Idaho: U.S. Geological Survey Water-Resources Investigations Report 90-4147 (DOE/ID-22092), 18 p.

\section{3, Concentrations of tritium and} strontium-90 in water from selected wells at the Idaho National Engineering Laboratory after purging one, two, and three borehole volumes: U.S. Geological Survey WaterResources Investigations Report 93-4201 (DOE/ID-22111), $21 \mathrm{p}$.

Bartholomay, R.C., Edwards, D.D., and Campbell, L.J., 1992, Radionuclides, inorganic constituents, organic compounds, and bacteria in water from selected wells and springs from the southern boundary of the Idaho National Engineering Laboratory to the Hagerman area, Idaho, 1990: U.S. Geological Survey Open-File Report 92-91 (DOE/ID-22102), $42 \mathrm{p}$.

1993, Radionuclides, inorganic constituents, organic compounds, and bacteria in water from selected wells and springs from the southem boundary of the Idaho National Engineering Laboratory to the Hagerman area, Idaho, 1991: U.S. Geological Survey Open-File Report 93-102 (DOE/ID-22108), $42 \mathrm{p}$.

Bartholomay, R.C., and Knobel, L.L., 1989, Mineralogy and grain size of surficial sediment from the Little Lost River and Birch Creek drainages, Idaho National Engineering Laboratory, Idaho: U.S. Geological Survey Open-File Report 89-385 (DOE/ID-22082), $19 \mathrm{p}$.
Bartholomay, R.C., Knobel, L.L., and Davis, L.C., 1989, Mineralogy and grain size of surficial sediment from the Big Lost River drainage and vicinity, with chemical and physical characteristics of geologic materials from selected sites at the Idaho National Engineering Laboratory, Idaho: U.S. Geological Survey Open-File Report 89-384 (DOE/ID22081), $74 \mathrm{p}$.

Bartholomay, R.C., Knobel, L.L., and Tucker, B.J., 1993, Chemical constituents in water from wells in the vicinity of the Naval Reactors Facility, Idaho National Engineering Laboratory, Idaho, 1990-91: U.S. Geological Survey Open-File Report 93-34 (DOE/ID22106), $70 \mathrm{p}$.

Bennett, C.M., 1990, Streamflow losses and ground-water level changes along the Big Lost River at the Idaho National Engineering Laboratory, Idaho: U.S. Geological Survey Water-Resources Investigations Report 90-4067, (DOE/ID-22091), 49 p.

Busenberg, Eurybiades, Weeks, E.P., Plummer, L.N., and Bartholomay, R.C., 1993, Age dating ground water by use of chlorofluorocarbons $\left(\mathrm{CCl}_{3} \mathrm{~F}\right.$ and $\left.\mathrm{CCl}_{2} \mathrm{~F}_{2}\right)$, and distribution of chlorofluorocarbons in the unsaturated zone, Snake River Plain aquifer, Idaho National Engineering Laboratory, Idaho: U.S. Geological Survey Water-Resources Investigations Report 93-4054 (DOE/ID22107), $47 \mathrm{p}$.

Cassidy, G.B., 1984, Idaho National Engineering Laboratory industrial waste management information for 1983 and record-to-date: U.S. Department of Energy, Waste Management Programs Division, Idaho Operations Office Publication, DOE/ID-10057 (83), 99 p.

Cecil, L.D., Knobel, L.L., Wegner, S.J., and Moore, L.L., 1989, Evaluation of field sampling and preservation methods for strontium-90 in ground water at the Idaho National Engineering Laboratory, Idaho: U.S. Geological Survey Water-Resources Investigations Report 89-4146 (DOE/ID22083), 24 p. 
Cecil, L.D., Orr, B.R., Norton, T., and Anderson, S.R., 1991, Formation of perched groundwater zones and concentrations of selected chemical constituents in water, Idaho National Engineering Laboratory, Idaho, 1986--88: U.S. Geological Survey Water-Resources Investigations Report 91-4166 (DOE/ID22100), 53 p.

Cecil, L.D., Parlimann, D.J., Edwards, D.D., and Young, H.W., 1994, Concentrations of dissolved radon-222 in water from selected wells and springs in Idaho, 1989-91: U.S. Geological Survey Open-File Report 94-66 (DOE/ID- 22113), 40 p.

Claassen, H.C., 1982, Guidelines and techniques for obtaining water samples that accurately represent the water chemistry of an aquifer: U.S. Geological Survey Open-File Report 82-1024, 49 p.

Currie, L.A., 1984, Lower limit of detectiondefinition and elaboration of a proposed position for radiological effluent and environmental measurements: U.S. Nuclear Regulatory Commission NUREG/CR-4007, $139 \mathrm{p}$.

Davis, L.C., and Pittman, J.R., 1990, Hydrological, meteorological, and geohydrological data for an unsaturated zone study near the Radioactive Waste Management Complex, Idaho National Engineering Laboratory, Idaho1987: U.S. Geological Survey Open-File Report 90-114 (DOE/ID-22086), 208 p.

Edwards, D.D., Bartholomay, R.C., and Bennett, C.M., 1990, Nutrients, pesticides, surfactants, and trace metals in ground water from the Howe and Mud Lake areas upgradient from the Idaho National Engineering Laboratory, Idaho: U.S. Geological Survey Open-File Report 90-565 (DOE/ID-22093), 19 p.

Energy Research and Development Administration, 1977, Waste management operations, Idaho National Engineering Laboratory, Idaho: Final Environmental Impact Statement, ERDA-1536, 719 p.
Fishman, M.J., and Friedman, L.C., eds., 1989, Methods for determination of inorganic substances in water and fluvial sediments: U.S. Geological Survey Techniques of WaterResources Investigations, book 5, chap. A1, $545 \mathrm{p}$.

Goerlitz, D.F., and Brown, Eugene, 1972, Methods for analysis of organic substances in water: U.S. Geological Survey Techniques of WaterResources Investigations, book 5, chap. A3, $40 \mathrm{p}$.

Harenberg, W.A., Jones, M.L., O’Dell, I., Brennan, T.S., and Lehmann, A.K., 1991, Water resources data, Idaho, water year 1990: U.S. Geological Survey Water-Data Report ID-90-1, $641 \mathrm{p}$.

--1992, Water resources data, Idaho, water year 1991-volume 1. Great Basin and Snake River Basin above King Hill: U.S. Geological Survey Water-Data Report ID-91-1, 337 p.

Harenberg, W.A., Jones, M.L., O'Dell, I., and Cordes, S.C., 1990, Water resources data, Idaho, water year 1989: U.S. Geological Survey Water-Data Report ID-89-1, 681 p.

Idaho Department of Health and Welfare, 1977, Idaho regulations for public drinking water systems: Idaho Department of Health and Welfare, Division of Environment Publication, Title 1, Chapter 8, $44 \mathrm{p}$.

Jones, P.H., 1961, Hydrology of waste disposal, National Reactor Testing Station, Idaho, an interim report: U.S. Atomic Energy Commission, Idaho Operations Office Publication, IDO-22042-USGS, 152 p.

Knobel, L.L., Bartholomay, R.C., Cecil, L.D., Tucker, B.J., and Wegner, S.J., 1992, Chemical constituents in the dissolved and suspended fractions of ground water from selected sites, Idaho National Engineering Laboratory and vicinity, Idaho, 1989: U.S. Geological Survey Open-File Report 92-51 (DOE/ID-22101), $56 \mathrm{p}$. 
Knobel, L.L., Bartholomay, R.C., Wegner, S.J., and Edwards, D.D., 1992, Chemical constituents in water from wells in the vicinity of the Naval Reactors Facility, Idaho National Engineering Laboratory, Idaho, 1989-90: U.S. Geological Survey Open-File Report 92-156 (DOE/ID-22103), 38 p.

Knobel, L.L., and Mann, L.J., 1988, Radionuclides in ground water at the Idaho National Engineering Laboratory, Idaho: U.S. Geological Survey Open-File Report 88-731 (DOE/ID-22077), 37 p.

Knobel, L.L., and Mann, L.J., 1993, Sampling for purgeable organic compounds using positivedisplacement piston and centrifugal submersible pumps-a comparative study: Ground Water Monitoring Review, Spring 1993, p. 142-148.

Lamke, R.D., 1969, Stage-discharge relations on Big Lost River within National Reactor Testing Station, Idaho: U.S. Geological Survey Open-File Report (IDO-22050), 29 p.

Lewis, B.D., and Jensen, R.G., 1984, Hydrologic conditions at the Idaho National Engineering Laboratory, Idaho, 1979-1981 update: U.S. Geological Survey Hydrologic Investigations Atlas HA-674, 2 sheets.

Liszewski, M.J., and Mann, L.J., 1992, Purgeable organic compounds in ground water at the Idaho National Engineering Laboratory, Idaho, 1990 and 1991: U.S. Geological Survey Open-File Report 92-174 (DOE/ID22104), $19 \mathrm{p}$.

Liszewski, M.J., and Mann, L.J., 1993, Concentrations of 23 trace elements in ground water and surface water at and near the Idaho National Engineering Laboratory, Idaho, 1988-91: U.S. Geological Survey Open-File Report 93-126 (DOE/ID-22110), 44 p.
Litteer, D.L., and Peterson, C.N., 1990, Idaho National Engineering Laboratory industrial waste management information for 1989 and record-1o-date: U.S. Department of Energy, Waste Management Programs Division, Idaho Operations Office Publication, DOE/ID10057 (89), [117] p.

Litteer, D.L., and Reagan, B.D., 1990, Idaho National Engineering Laboratory radioactive waste management information for 1989: U.S. Department of Energy, Waste Management Programs Division, Idaho Operations Office Publication, DOE/ID-100545 (89) [503] p.

Litteer, D.L., Peterson, C.N., and Sims, A.M., 1991a, Idaho National Engineering Laboratory industrial waste management information for 1990 and record-to-date: U.S. Department of Energy, Waste Management Programs Division, Idaho Operations Office Publication, DOE/ID-10057 (90), [121] p.

----1991b, Idaho National Engineering Laboratory radioactive waste management information for 1990: U.S. Department of Energy, Waste Management Programs Division, Idaho Operations Office Publication, DOE/ID10055 (90), [595] p.

1993, Idaho National Engineering Lahoratory radioactive waste management information for 1991 and record-to-date: U.S. Department of Energy, Waste Management Programs Division, Idaho Operations Office Publication, DOE/ID-10054 (91), [569] p.

Lucius, J.E., Olhoeft, G.R., Hill, P.L., and Duke, S.K., 1989, Properties and hazards of 108 selected substances: U.S. Geological Survey Open-File Report 89-491, 538 p.

Mann, L.J., 1986, Hydraulic properties of rock units and chemical quality of water for INEL1-a 10,365-foot deep test hole drilled at the Idaho National Engineering Laboratory, Idaho: U.S. Geological Survey WaterResources Investigations Report 86-4020 (DOE/ID-22070), 23 p. 
---1989, Tritium concentrations in flow from selected springs that discharge to the Snake River, Twin Falls-Hagerman area, Idaho: U.S. Geological Survey Water-Resources Investigations Report 89-4156 (DOE/ID22084), 20 p.

----1990, Purgeable organic compounds in ground water at the Idaho National Engineering Laboratory, Idaho--1988 and 1989: U.S. Geological Survey Open-File Report 90-367 (DOE/ID-22089), 17 p.

Mann, L.J., and Beasley, T.M., 1994, Iodine-129 in the Snake River Plain aquifer at and near the Idaho National Engineering Laboratory, Idaho, 1990-91: U.S. Geological Survey Water-Resources Investigations 94-4053 (DOE/ID-22115), 27 p.

Mann, L.J., and Cecil, L.D., 1990, Tritium in ground water at the Idaho National Engineering Laboratory: U.S. Geological Survey Water-Resources Investigations Report 90-4090 (DOE/ID-22090), 35 p.

Mann, L.J., Chew, E.W., Morton, J.S., and Randolph, R.B., 1988, Iodine-129 in the Snake River Plain aquifer at the Idaho National Engineering Laboratory, Idaho: U.S. Geological Survey Water-Resources Investigations Report 88-4165 (DOE/ID22076), 27 p.

Mann, L.J., and Knobel, L.L., 1987, Purgeable organic compounds in ground water at the Idaho National Engineering Laboratory, Idaho: U.S. Geological Survey Open-File Report 87-766 (DOE/ID-22074), 23 p.

--1988, Concentrations of nine trace metals in ground water at the Idaho National Engineering Laboratory, Idaho: U.S. Geological Survey Open-File Report 88-332 (DOE/ID22075), $17 \mathrm{p}$.

--1990, Radionuclides, metals, and organic compounds in water, eastern part of $A \& B$ Irrigation District, Minidoka County, Idaho: U.S. Geological Survey Open-File Report 90-191 (DOE/ID-22087), 36 p.
Morris, D.A., Barraclough, J.T., Chase, G.H., Teasdale, W.E., and Jensen, R.G., 1965, Hydrology of subsurface waste disposal, National Reactor Testing Station, Idaho, annual progress report, 1964: U.S. Atomic Energy Commission, Idaho Operations Office Publication, IDO-22047-USGS, 186 p.

Morris, D.A., Barraclough, J.T., Hogenson, G.M., Shuter, Eugene, Teasdale, W.E., Ralston, D.A., and Jensen, R.G., 1964, Hydrology of subsurface waste disposal, National Reactor Testing Station, Idaho, annual progress report, 1963: U.S. Atomic Energy Commission, Idaho Operations Office Publication, IDO22046-USGS, 97 p.

Morris, D.A., Hogenson, G.M., Shuter, Eugene, and Teasdale, W.E., 1963, Hydrology of waste disposal, National Reactor Testing Station, Idaho, annual progress report, 1962: U.S. Atomic Energy Commission, Idaho Operations Office Publication, IDO-22044USGS, $99 \mathrm{p}$.

Olmsted, F.H., 1962, Chemical and physical character of ground water in the National Reactor Testing Station, Idaho: U.S. Atomic Energy Commission, Idaho Operations Office Publication, IDO-22043-USGS, 142 p.

Orr, B.R., and Cecil, L.D., 1991, Hydrologic conditions and distribution of selected chemical constituents in water, Snake River Plain aquifer, Idaho National Engineering Laboratory, Idaho, 1986 to 1988: U.S. Geological Survey Water-Resources Investigations Report 91-4047 (DOE/ID22096), $56 \mathrm{p}$.

Orr, B.R., Cecil, L.D., and Knobel, L.L., 1991, Background concentrations of selected radionuclides, organic compounds, and chemical constituents in ground water in the vicinity of the Idaho National Engineering Laboratory: U.S. Geological Survey WaterResources Investigations Report 91-4015 (DOE/ID-22094), $52 \mathrm{p}$. 
Ott, D.S., Edwards, D.D., and Bartholomay, R.C., 1992, Water-level data for selected wells on or near the Idaho National Engineering Laboratory, Idaho, 1983 through 1990: U.S. Geological Survey Open-File Report 92-643 (DOE/ID-22105), 307 p.

Pittman, J.R., 1989, Hydrological and meteorological data for an unsaturated zone study near the Radioactive Waste Management Complex, Idaho National Engineering Laboratory, Idaho--1985-86: U.S. Geological Survey Open-File Report 89-74 (DOE/ID22079), $175 \mathrm{p}$.

Pittman, J.R., Jensen, R.G., and Fischer, P.R., 1988, Hydrologic conditions at the Idaho National Engineering Laboratory, 1982 to 1985: U.S. Geological Survey WaterResources Investigations Report 89-4008 (DOE/ID-22078), 73 p.

Polzer, W.L., Percival, D.R., and Barraclough, J.T., 1976, Special analyses for plutonium and americium in water from the Snake River Plain aquifer: U.S. Department of Energy, Idaho Operations Office Publication, IDO12081-USGS, 9 p.

Pritt, J.W., and Jones, B.E., eds., 1989, 1990 National Water Quality Laboratory services catalog: U.S. Geological Survey Open-File Report 89-386, parts 1-5.

Robertson, J.B., 1974, Digital modeling of radioactive and chemical waste transport in the Snake River Plain aquifer at the National Reactor Testing Station, Idaho: U.S. Geological Survey Open-File Report IDO22054, $41 \mathrm{p}$.

-.-1977, Numerical modeling of subsurface radioactive solute transport from wasteseepage ponds at the Idaho National Engineering Laboratory: U.S. Geological Survey Open-File Report 76-717 (IDO-22057), $68 \mathrm{p}$.
Robertson, J.B., and Barraclough, J.T., 1973, Radioactive- and chemical-waste transport in ground water at the National Reactor Testing Station, Idaho, 20-year case history and digital model: Underground Waste Management and Artificial Recharge, v. 1, p. 291-322.

Robertson, J.B., Schoen, Robert, and Barraclough, J.T., 1974, The influence of liquid waste disposal on the geochemistry of water at the National Reactor Testing Station, Idaho, 1952-1970: U.S. Geological Survey OpenFile Report (IDO-22053), $231 \mathrm{p}$.

Stevens, H.H., Jr., Ficke, J.F., and Smoot, G.F., 1975, Water temperature - influential factors, field measurement, and data presentation: U.S. Geological Survey Techniques of WaterResources Investigations, book 5, chap. D1, $65 \mathrm{p}$.

U.S. Environmental Protection Agency, 1989, Protection of environment-Code of Federal Regulations 40: Washington, D.C., Office of the Federal Register, National Archives and Records Administration, Parts 100 to 149 , $948 \mathrm{p}$.

U.S. Geological Survey, 1985, National water summary, 1984--Hydrologic events, selected water-quality trends, and ground-water resources: U.S. Geological Survey WaterSupply Paper 2275, 467 p.

Walker, E.H., 1964, Subsurface geology of the National Reactor Testing Station, Idaho: U.S. Geological Survey Bulletin 1133-E, 22 p.

Walker, F.W., Parrington, J.R., and Feiner, Frank, 1989, Nuclides and isotopes, chart of the nuclides (14th ed.): General Electric Company, Nuclear Energy Operations, 57 p.

Wegner, S.J., 1989, Selected quality assurance data for water samples collected by the U.S. Geological Survey, Idaho National Engineering Laboratory, 1980 to 1988: U.S. Geological Survey Water-Resources Investigations Report 89-4168 (DOE/ID22085), $91 \mathrm{p}$. 
Wegner, S.J., and Campbell, L.J., 1991, Radionuclides, chemical constituents, and organic compounds in water from designated wells and springs from the southern boundary of the Idaho National Engineering Laboratory to the Hagerman area, Idaho, 1989: U.S. Geological Survey Open-File Report 91-232 (DOE/ID22098), 49 p.

Wershaw, R.L., Fishman, M.J., Grabbe, R.R., and Lowe, L.E., 1987, Methods for the determination of organic substances in water and fluvial sediments: U.S. Geological Survey Techniques of Water-Resources Investigations, book 5 , chap. A3, 80 p.

Wood, W.W., 1981, Guidelines for collection and field analysis of ground-water samples for selected unstable constituents: U.S. Geological Survey Techniques of Water-Resources Investigations, book 1, chap. D2, 24 p.

Zohdy, A.A.R., and Stanley, W.D., 1973, Preliminary interpretation of electrical sounding curves obtained across the Snake River Plain from Blackfoot to Arco, Idaho: U.S.

Geological Survey Open-File Report, 3 p. 